
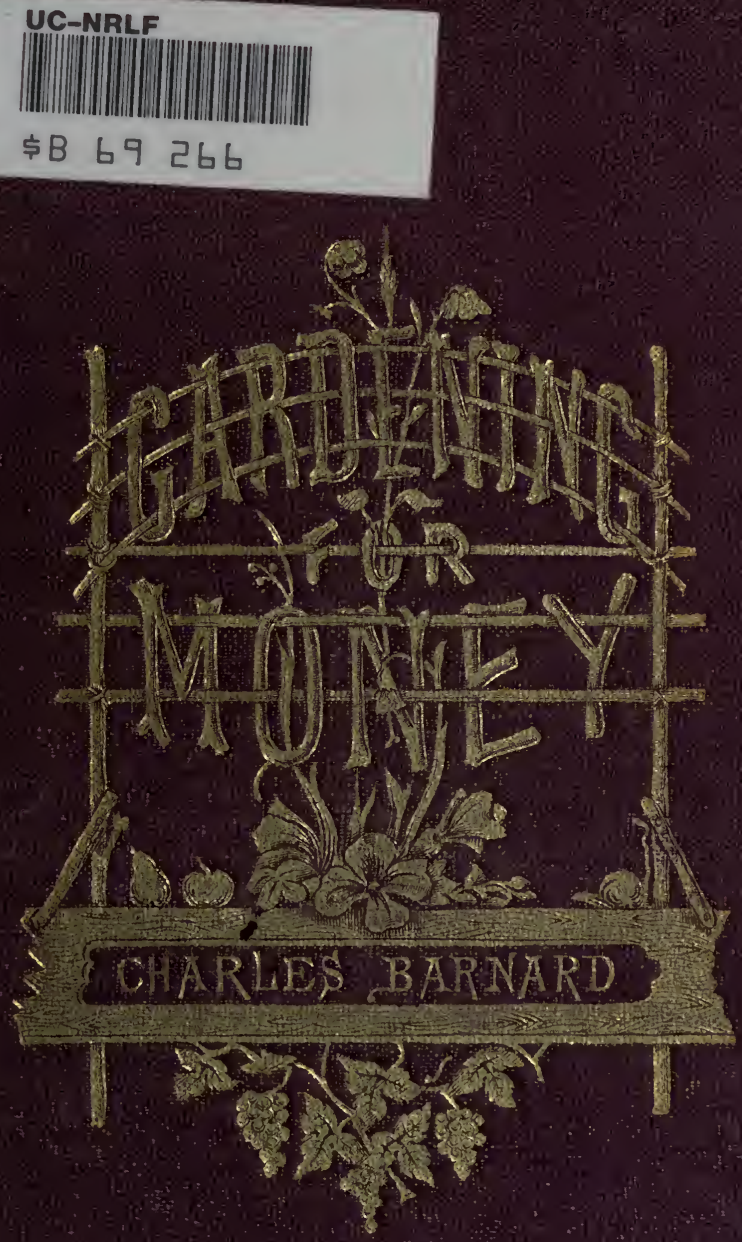
63
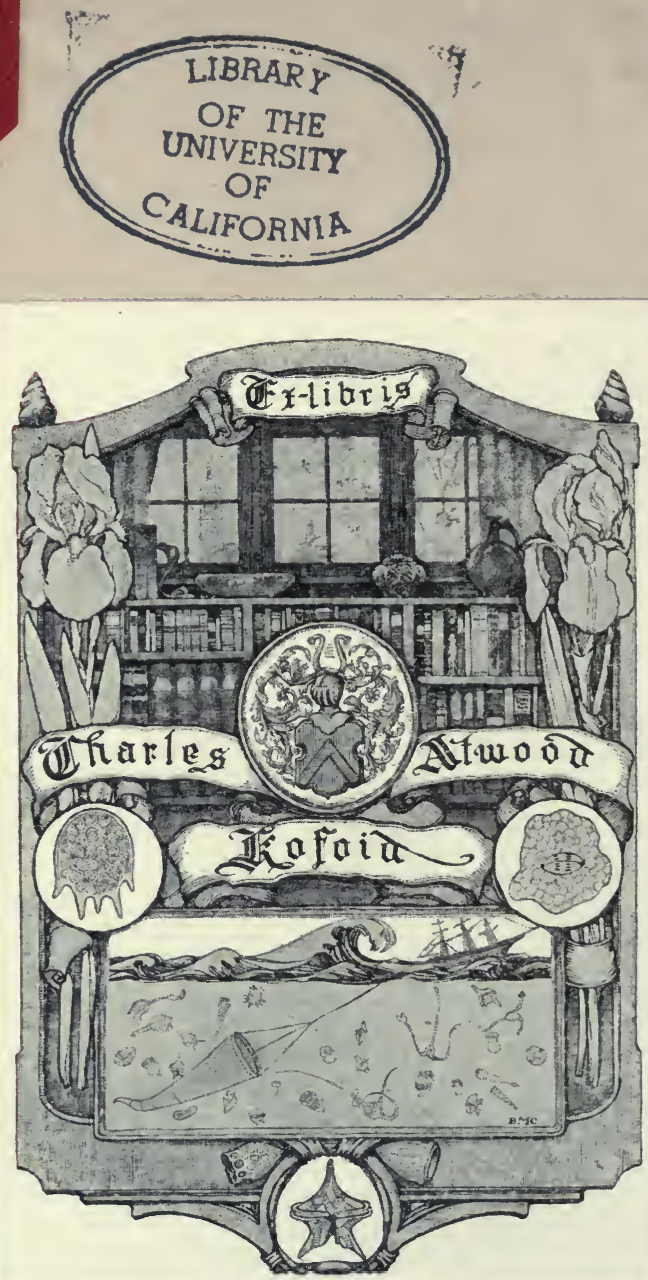

Digitized by the Internet Archive in 2007 with funding from Microsoft Corporation 




\title{
GARDENING FOR MONEY.
}

\section{FOW IT WAS DONE,}

\author{
FLOWERS, \\ STRA WBERRIES, \\ VEGETABLES.
}

BY CHARLES BARNARD.

1).

L ORI N G, Publis her,

Cor. Bromfield and Wasmington Streets,

B OSTON. 
Entered, according to Act of Congress, in the year 1869, by A. K. L O R I N G,

In the Ilerk's Office of the District Court for the District of Massachusetts.

\section{。}




\section{1 \\ B35}

\section{F L 0 W E R S.}

\section{MY TEN-ROD FARM; OR, HOW I BECAME A FLORIST.}

MRS. MARIA GILMIAN'S SUCCESSFUL EXPERIMENT. 



\section{MY TEN-ROD FARM;}

\section{OR, \\ HOW I BECAME A FLORIST.}

CHAPTER I.

THE COMING OF TROUBLE. - THE BEGINNING OF HOPE.

Mr name is Maria Gilman. I am a widow. These are my two children,- John, fifteen years of age, who is studying to be a gardener, and Mary, twelve years old, who attends the high school at the Centre, where I reside. I own the house in which I live, the furniture, the large greenhouse in the yard, and, in fact, the entire estate, - one hundred and sixty feet by seventy-five,-which I familiarly speak of as my Ten-Rod Farm. I keep a man-servant and a maid-of-all-work. My income is two thousand dollars a year, and $I$ am out of debt. Five years ago $I$ was poor and in great affliction. Now I am independent, though not quite free from sorrow, for the memory of my husband will always remain with me.

If it would interest you, I will give you a portion of my life history, and explain how it was that I, a comparatively 
poor woman, have made a place for myself in the world and become rich, and all this with my own hands.

My parents were in comfortable circumstances, and, like most girls of my class, I was brought up with little or no knowledge of how to work. I could play and sing as well as most girls. I knew how to sew ; but, beyond this, comparatively nothing. I was married to Mr. Gilman when I was twenty. My parents both died soon after. My new home was always one of ease and comfort,-my husband being foreman of the large mill you see yonder, and in receipt of a liberal income. My life from my youth up was one long happiness, until that dark and sad day when my husband was brought home, on a lovely June morning, mangled and dead,-killed in the mill. From that moment my sorrows began. Let me pass over the terrible days that followed. I do not remember much about them. I seemed lost in a horrid dream, and only awoke to the sad reality when I was forced to attend to the pressing wants of myself and children.

Then I knew the meaning of loneliness and poverty. At first I could not look at my condition. They said something to me about the house being sold.

"Sell my husband's house and home! Leave this place, leave my home, go away from this garden planted and tended by his hands? No, I will never do it."

"But you must. There is a mortgage on it, and you had better sell out and find a room or two to live in." It 
was my brother Joseph who had said this. He lives near by. He is a married man, with a large family, and is far from rich. Doubtless he was right in what he said. I did not know how that was. I was in too much trouble to think of anything then.

"Joseph," I said, "give me time to think. Wait a few days, and I will talk with you again." Going to my room, I sat down to think. Yes, to think ! Thinking was something I had never been called upon to do. It had been my lot simply to enjoy. I looked over the state of affairs, and found these hard facts: the house I occupied was worth two thousand dollars; part of the purchase money was paid, and five hundred dollars still remained on a mortgage; there was an insurance of two thousand dollars on my husband's life. And what else? Nothing. Not a cent of income of any sort. When the bills of the funeral were paid I found I should have just twenty-five dollars on hand from my husband's wages, and no more. Give up the house I would not, - at least, not until I was obliged to. No! I would stay where I was, - find something to do and support myself and children as best I could. But then what could I do? Teach? No, indeed. All I knew of music when I was a girl had been lost long ago. Take a school? Could I get one? I imagined not. All the places are spoken for long before they are vacant. What, then, could I do ? Plainly, nothing but sewing. I must support myself by my needle. Thank God, I could do that. Accord- 
ingly, the next day, after sending the children to school, I took the train for the city in search of work. Need I tell you the miserable story? How I went from shop to shop literally "despised and rejected of men." The second day was as the first - nothing. The third was still more hopeless. The fourth day I found some work, and took it home. After sitting up part of that night, all the next day, and far into the next evening, I finished the work, and carried it to the city, and received for my eighteen hours' labor, only seventy-nine cents. The price was so out of all proportion to the amount of toil, and seemed to me so utterly cruel, that I took the money; found my way to the cars somehow, and finally reached my home, tired and almost broken-hearted. I was awakened the next morning by confused noises in the street. Wondering what it could mean, I got up and went down stairs. I found the children already up and trying to make a breakfast of bread and water. "What is the matter?" asked I.

"Fourth of July, mother. Didn't you know it? I am going to the pond to fish with the boys." The Fourth of July, and everybody happy and making holiday. All happy but me. And then - more tears. After a while I busied myself about the house until my brother Joseph came in after dinner. He began at once.

"Now, Maria, do listen to reason. Sell this house, invest the money with the insurance, and live on the interest. It will give you about two hundred a year, and you can 
get on very well with that, if you put Johnny at a trade, and let Mary go into the factory."

"Joseph," I cried, "what do you mean? My Mary in the mill?"

"Well, just as you like, - I can't help you."

After he had gone, I lay down sick, weary, and utterly dejected.

I had not been in my room long, before Mary came to me and said a young lady wished to see me at the door. Washing away the tear-stains, I went down to the front door, and found Miss Dwight from the grand house over the way.

"Mrs. Gilman, I have a great favor to ask; come into the garden a moment."

Throwing something over my head, I followed her out into my flower-garden. The sun was bright, and the air fragrant with mignonette. The cheerful, balmy warmth revived me, and I felt better. We went into the walk, among the flowers. It was my husband's garden. He was passionately fond of flowers, and had planted and tended them with his own hands. I had not been in the garden since he died, yet the sight did not make me sad; I was rather pleased than otherwise. He seemed to be nearer to me, and from that moment I began to love the flowers for his sake. Presently Miss Dwight stopped before a brilliant geranium, and, turning to me, said :-

"Mrs. Gilman, we have friends to dinner to-day. We ordered some flowers of the florist, but they have not come, 
and I wish you to do me the favor of selling some of yours."

"Sell my flowers! No, indeed! I will give you all you wish."

"No, I cannot take them so; I wish to buy them."

"What, sell my husband's flowers? Oh, no!"

"Now, Mrs. Gilman, please listen a moment. Flowers are a merchantable article. You have them, and I wish to purchase. I am sure your husband would not object, were he alive."

Then I thought of my poverty, of my search for work, and of the children. That decided me.

"Yes," I said at last, "I will sell you some, but I know nothing of their value."

"But I do. I buy them often, and will give you just what others charge me."

Without more words, she took out a pair of scissors and began snipping off the flowers. At first, I could not bear to see her do it, and walked apart by myself. After a while, . I thought better of it, and even helped her fill her basket. When it was full, she turned to me with a smile, and said : -

"I am greatly obliged to you, Mrs. Gilman. These are just what I wanted." And, handing me a bill, she went away.

Re-entering the house, I drew down the curtains, to shut out the sight and sound of the happy people in the village 
street, and sat down to think over my wretched lot. While I turned over in my mind all the sad detafls of my situation, I twisted the bit of paper in my hand till I nearly tore it in two. This brought me to myself again, and I mechanically unrolled the bill and looked at it.

"There must be some mistake. What could she have been thinking of? She has paid me too much. It was not possible that those flowers were worth five dollars." And yet, there it was, - a new, clean, five-dollar bill, more money than I could earn.in a week of sewing !

In a moment I had my things on, and fairly flew across the stre $\theta^{\prime}$, and hastily rang the Dwights' bell. To the servant who came to the door I handed the bill, saying:"Give that to Miss Dwight, if you please, and tell her that Mrs. Gilman thinks there is some mistake."

In a few moments the servant returned, and, giving me the bill again, informed me, with Miss Dwight's compliments, that everything was quite correct.

Turning from their door, I walked slowly home just as the sun was going down. As I entered my gate, a new idea suddenly came to me. Quickening my pace, I ran upstairs to my room. No time for tears now. My opportunity had come. God had not forsaken the widow and fatherless. It only remained for me to improve the opportunity which $\mathrm{He}$ had thrown in my path.

Taking a bandbox from the closet, and an old penknife from my husband's bureau, I returned to the garden and 
began to cut the flowers, - verbenas, geraniums, mignonnette, fuchsias, and roses, by the handful. Filling my box, I carried them into the kitchen, and, procuring all the empty pans I could find, I placed the flowers in water and arranged them on the table. "No, that will not do; the children will see them." So, one at a time, I carried the pans, now glowing with color, downstairs, and placed them all in the cool, dark cellar. The next morning, I was up very early; and, after getting the children's breakfast ready for them, gathered all the flowers together from the cellar, put them in the bandbox, got my hat, shawl, and veil, and started for the railroad.

The cars had not arrived when I reached the station; so I was obliged to wait among a crowd of men and boys and a few girls, all going to their work in the city by the first morning train. Soon the engine appeared, and we started. I felt lonely indeed, and was almost the only woman in the throng. The conductor knew me, but seemed puzzled to see me. "What brings you here at this early hour?" I dare say, he thought.

In due time we ran into the great depot in the city. I had never been in the streets so early in the morning before. Everything seemed strange. Plenty of people were stirring, but they were all of a class which I had seldom met. Only a few stores were open, and before these, boys and men were busily sweeping out and taking down the shutters. I had to pick my way along carefully, for it did seem as if 
the servants were washing down all the door-steps at once.

Coming out upon Trimountain Avenue, near the park, I began to look about for a flower-stand, or seed store. Soon I came to one, and looked in. There was no one there but a boy with his broom, so I passed on. Presently I came to another. The clean marble floor and handsome showcase, filled with all sorts of garden nicknacks, tempted me in. Seeing a young man behind the counter, I went up to him, and, opening my box, laid it upon the wet marble slab before him.

"Are those flowers for sale?" said he.

"Yes, sir."

"What will you take for them?"

"Anything that is fair. I know nothing of their value. I trust to you to give me whatever they are worth."

He at once turned the flowers out, and, pushing my box towards me, handed me a bill. Placing the box under my shawl, I went out, and reached the cars in time for the first train home. At my door I met the children.

"Why, where have you been, mother? We thought you must have run away."

"No, no. I have been to town on an errand among the shops."

"What! shopping at this time of day?"

"Yes; but come, eat your breakfast and be off to school, for I am busy now." 
My pride forced me to say this. It was not strictly true; yet I had been shopping, - as a seller.

After they had gone to school, I put away my things, and carefully locked up the still fragrant bandbox. I did not wish my children to know what I had done. It was a foolish pride, - that, after a fall or two, was quite cured. Taking my purse from my pocket, I unrolled the bill I received for the flowers. It was a two-dollar bill. To tell the truth, I was a little disappointed. From the sum I had received from Miss Dwight, I expected to get more than two dollars. But then, I remembered that Miss Dwight took them at first-hand, whereas the man bought at wholesale to sell again. However, I put the two dollars with Miss Dwight's five, and, going to market, I procured enough to supply our table for several days. After bringing my purchases home, I found I had still one dollar left. Quite overjoyed at the new turn affairs had taken, I put on my sun-bonnet and went out, ostensibly to walk in the garden, but really to take an account of stock in my new trade. I went carefully over the whole ground; counted every plant, and tried to estimate how much money I could cut from my flower-beds. If I could do as well as I had this morning, I might snap my fingers at the sewing-shops, keep my house, and be independent of Joseph and every one else. Soon I was surprised to hear the factory-bell ring for dinner, and directly the children returned from school. Going into the house, I spread a bountiful table, 
and sat down to dinner with a wonderful appetite. It seemed as if I had never been so hungry, nor in such good health and spirits before.

The next morning I again made my appearance before the man in the flower store. This time he did not seem so much pleased with my flowers. He looked at them for a moment, and then carefully picked them over, arranging them in two heaps upon the wet counter.

"I can't take all of these. Those," said he, pointing to one heap, "are not salable. They drop too quick."

To this I could say nothing, so I took up my box and prepared to leave.

But he detained me, and said, "I will pay you for the good ones, but you need not bring those poor sorts any more."

He then passed me a bill with one hand, and with the other pushed one of the little heaps of flowers from the counter to the floor behind him. Just as they fell over I stole a glance at them, and observed among them some petunias and marigolds.

So, then, I have learned one thing to-day. Petunias and marigolds are not salable. As soon as I reached the train, and was alone in the car, for there were but few people travelling at that hour of the morning, I opened the bill and again found two dollars.

The next day was Sunday. It being a day of rest, I could not gather my flowers at evening, and the next morn- 
ing I was obliged to get up quite early, in order to cut them in time for the early train. By working very hard and fast I managed to get a box full, carefully omitting the petunias and marigolds.

When I opened my box on the counter, in the flower store, I found many of my flowers had wilted. Quite mortified at the wretched appearance they presented, I laid them before the man, expecting he would condemn the whole of them this time.

As soon as he saw them he took up a watering-pot, and fairly deluged them with water.

"You cut them in the sunlight," said he. "If you wish to have them fresh, you must cut them the evening before." Much wondering at this, I took my money and went home. This time I found I only had a dollar and a half. So much for not knowing that flowers must not be cut in the morning. However, the experience was well worth the cost. After breakfast, I took out my sewing and sat down to think over my new business. If I could go out in my garden every day, and in a few moments cut enough flowers to support me through that day, I should be well off; for all the remainder of the day I could be busy about something else. But could I do this? Would not the garden require some attention? I would go out and see. Suiting the action to the word, I put on my sun-bonnet, and started out to inspect. The first things I noticed were the weeds. Yes, weeds, plenty of them. Surely this will not 
do. I can't have flowers and weeds too. Ignorant as I was, I knew enough for that. Selecting a corner where I could not be seen from the street, I set to work pulling them up by hand. Pretty hard work I soon found it, and it did seem as if the sun was very powerful that day. After weeding a while, I had to give it up and rest. Walking about to get rid of the back-ache, I came to a large bed of petunias. What a pity there are so many of them, and yet no income from them! So mercenary had I become, weighing flowers by their money value only! Soon I went back to my weeding. Now this is all very well, but it is terrible hard work. Why did I not think of it before? Get a hoe. Going to the tool-room I found one, and returned to my work. Now, this is something like. I can get on twice as fast. Dear me! is it twelve already? Where has the morning gone? When the children came, we had dinner. Dear me! again, how hungry I am. I never had such an appetite! After dinner, I went at it again. After a while, $I$ found my hoe so heavy that $I$ sat down on a stone seat near a bed of marigolds. They were very weedy. What a pity to spend labor on them for nothing! I wish they had never been planted. About six, I got my box and began to cut again for the next day's sale. Somehow the flowers did not seem as plenty as on the day before. All I could get for them, the next day, was a dollar and seventy-five cents. The day after, I again tried the weeding. I was very tired at night, but it was vastly pleas- 
anter work than sewing, and already I felt the good effects of my out-door life. That evening I experienced still more difficulty in filling my box.

"You cut too often," said the man in the store, the next day. "If you cut every other day; you will allow them time to recover, and get just as much money. You did not bring my mignonnette this morning."

"No ; my bed is small, and I cut it quite close."

"You should plant another; it will come in. late for fall flowers."

"Where can I get seed?" said I.

"Oh, we have it. Johnny, bring the lady an ounce of mignonnette."

The boy brought the seed and placed it in my box; not quite knowing what to do, I hesitated about taking it.

"I have not any room to plant more," said I.

"Make room. Pull up something else."

Taking my money, and paying the lad twenty cents for the seed, I went home.

After the children had gone to school, I went into the garden to make my first horticultural venture. Now what shall I remove in order to gain room? Oh, the petunias. Not without a pang to think I was tearing up my husband's pets, I ruthlessly rooted them all out and threw them on the path. What a deal of trouble I might have saved myself, if I could have pulled up the weeds at the same time! Raking the ground smootl, I got ready to plant. Well, 
how is it done? I never planted a seed in my life. "Directions for planting." How nice! Full directions on the package. "Sow thinly on the surface, and rake it in." And I did, and afterwards contemplated my newmade bed with considerable satisfaction. It was not a large bed. About twenty feet by three.

"Law sakes! do look at Miss Gilman."

Turning round, to see where the voice that suddenly broke on my ear came from, I beheld the ruddy face of my next neighbor, surmounted by a "coal-scuttle" bonnet, peering over the fence at me.

"Good-morning, Mrs. Jacques. Fine day, is it not?"

"Day's fine enough, but what on airth are you doing?"

"Me? Oh, I am putting my garden to rights."

"I should say you was. Look at all them petunias lying there! I should say you was putting them to wrongs."

Finding myself caught, I replied that "I never did think much of petunias. I preferred mignonnette."

"What, planting more, with all that bed full now. Well, I never!"

Upon which she put up her linen-gloved hands and disappeared.

"I shall not hear the last of that, I know," and, gathering up the remains of the petunias, I went into the house.

Soon after dinner, I finished the weeding, and, as there did not seem to be anything more to do that day, I improved the time in some other way. As I intended to take 
the young man's advice, and not cut till the next day, I had a nice long evening at my sewing.

The following morning $I$ again inspected my garden, and found the flowers were coming out grandly. All the summer roses seemed to be doing their best, and verbenas, fuchsias, and lilies, all exhibited a cheerful show of flowers, ready to be turned into money for myself and little ones. I fairly laughed to see them. Perhaps if I had known how much labor and trouble they would give me before the summer was over I should not have been so cheerful; yet with all the labor came a sure reward. I cut an extra large lot that evening. I even called the children to help me, telling them I wished to send the flowers away.

I received two dollars and a half for this lot of flowers.

Again I omitted to cut the next day, and, on Saturday, took in a fine lot of flowers, as I thought. I found, however, that my ignorance again caused me a loss. All I received was one dollar and a half. Verbenas were not permanent enough. They could not be used for fine work. Only choice flowers were of any value in the summer. I must bring only nice green, buds, heliotrope, and choice stuff. Glad that my ignorance had not cost me more, I went home to the children, quite resolved on my future course. I had now found out one fact for certain. Flowers could be sold readily. Could I grow enough of them to support myself ?. That was a question I could not answer. But I could try. It would not cost much for the present, 
at least, and so far everything seemed encouraging. Yes, I would try. I would set up for a gardener. Why not? Could not I become a florist as well as a man? It was worth trying. It being Saturday, the children were both at home. After breakfast I called them to me and told them what I had been doing, and of my plans for the future. They did not quite understand it all, but were greatly pleased with the idea of working in the garden, and gathering the flowers.

"I can cut the roses with the scissors Aunt Charlotte gave me. Mayn't I, mother?"

"And I can rake the walks, and pull up the weeds, just as father used to do."

"Oh, you can't rake, Johnny. You aint big enough."

"Yes, I am. Mother knows I can."

"Yes, dears, you shall both help mother, and we shall get on famously together."

So.this is the way in which I took my children into partnership, and began life as a florist. That night I made a small blank-book out of a sheet of foolscap and-entered therein an account of the week's receipts. and expenditures. It stood somewhat in this wise :-

Received for flowers.

From last week, 900

Rec'd this week, 750

July 14.

$$
\overline{1650}
$$

Paid, 140

Paid.

For fares, .40

(6 seed, .20

6 fare, .80 
Fifteen dollars and ten cents so far, and little or no trouble as yet. It would be foolish to expect this all the time. Flowers could not be raised for nothing, or without labor. How much labor it did cost, and how much was left afterwards, must be told in the next chapter. 


\section{CHAPTER II.}

NEW FRIENDS AND NEW FLOWERS.

- The next day opened fine and warm. In the morning we went to church. My husband had fortunately paid for pew-rent in advance; so I resolved to occupy it as long as I could. I did not intend to take a back seat until obliged to. In the afternoon the heat was so oppressive that I stayed at home and read aloud to the children. In the midst of our reading I heard a low rumble as of distant thunder. Not thinking anything about it I continued reading. Again the thunder pealed, and louder than before. A shower was evidently approaching. Then I remembered the garden, and wondered what effect the rain would have upon my flowers. I must go out and have a look at it. Calling the children to see the coming storm, we went out to the yard. On going outside the front gate, I looked up the village street and saw dark masses of clouds piling up the northwestern sky. Calling their attention to the sight, I tried to explain to them that, threatening and terrible as it seemed, yet the rain would wash away the dust and revive the grass and the flowers.

"Yes, mother," said Johnny; "but won't it spoil all your flowers?" 
"Why, yes. That is a bright idea, Johnny! Now what shall we do? If we leave them where they are, we shall not have very nice-looking flowers to take to the store in the morning." Just then the village clock struck three. But it is Sunday. We should not work on Sunday. But we must. It cannot be helped. It is a work of necessity.

Getting my old box, I set the children at it, bidding them be careful and not injure the beds, and yet work as fast as they could. Hastily filling the box, I carried it to the house, emptied the flowers out upon the kitchen table, and returned for more. Suddenly I was startled by a loud clap of thunder, and by the noise of persons hurrying past our gate. Oh, here is the rain - and the people! I don't know which I dread most. Calling the children away, I seized the box and darted into the house. Just then the rain came down in torrents, and the sidewalk was filled with friends and neighbors hurrying home.

"Well, that was a lucky escape!"

But perhaps it was a foolish pride. I had no need to fear the opinion of the neighbors. What I had done was a work of positive necessity, and must be done even though it was Sunday.

I overslept myself the next morning, and was late to the train. I had hardly time to take the cars before they started. The car I entered was quite full of men and boys. I found an empty seat beside an elderly man, and, as he kindly made room for me, I sat down. Just as I did 
so, the cover of my box, which in my haste I had not fastened down, came off, displaying the brilliant contents.

"Them's fine flowers you have, ma'am."

I stared at the man, quite surprised at what seemed to me a piece of impertinence.

"No offence, ma'am, but they are fine ones."

"Yes," I said, and, replacing the cover of the box, I attempted to pull down my veil, to show that I did not care for further conversation.

"Goodness! I've left my veil at home. What shall I do now? Well, it can't be helped; I may as well put a cheerful face on it. Luckily I shall not meet any one I know or any of the Centre people. If I were at home I should have a fit of the blues, but here I am in the city and enough to do and think about in finding a market for my flowers."

While I was in the flower store, who should enter but my railroad acquaintance, carrying a small green box in his hand! Coming to the counter, he laid it down, and said to the man :-

"Good-morning, Thomas."

"Good-morning, Mr. McTernan. Have you any white flowers?"

"Tubes, jasmines, and liliums. Will that suit ye?"

Upon which he opened his box and took out a small handful of wax-like white flowers, with a most.overpowering fragrance. All this time I had resolutely turned my back 
upon the two men, determined not to be recognized. But my curiosity was too much for me.

"What are those flowers?"

"Tubes, ma'am."

"Tubes? I never saw or heard of them before!"

"Tuberoses," suggested Thomas, behind the counter.

"Are those tuberoses? I have heard of them, but never saw them before."

"Yes, ma'am," said Mr. McTernan. "There's the double tuberose."

He then turned out the remainder of his flowers, and afterward handed to the young man, who, as I had now discovered, rejoiced in the name of Thomas, a small slip of paper. Thomas merely glanced at it, and, writing something upon it, gave it back to my travelling companion. All these things I watched with interest, eager to find out all I could in relation to my new trade. But the man only took it and went away toward another part of the store.

On my way to the cars, I turned over in my mind what I had seen and heard in regard to this to me new flower.

I wonder if I could not grow tuberoses. Such flowers must be valuable. I wish I had been bright enough to ask the man about them. What is the use of my miserable pride? It is always standing in my way. Just because the man was illiterate, and had rough hands, I had avoided him. Ho was neatly but plainly dressed, and 
had a weather-stained, yet kindly and honest face. He must be a-

"Ma'am? Excuse me, ma'am, but I must speak to ye a moment."

Turning round to see who had the audacity to address me in the public street, I found Mr. McTernan, - box and all.

"Excuse me, ma'am, if I make bold to say that ye mustn't sell your flowers so cheap. Ye must charge him more. Make 'em pay - "

"Sir," I cried, "how dare you! What is it to you? I'll thank you to leave me."

"Just as ye like. But it was for your own good I was telling ye."

Somewhat mollified, I replied, "How is that?"

"Why, ye see that box of flowers ye had was worth more than he gave ye."

"How do you know anything about it?" said I, annoyed and perplexed at the whole adventure.

"Well, ma'am, I grows flowers myself, and I know what they are worth; and all he gave you was two dollars for the lot."

"How do you know what he gave me?"

"I seen him hand it ye."

Now, to tell the truth, I had not looked at the money; so I opened my purse, and sure enough it was two dollars. "And, ma'am, it's not right to take the money without 
looking at it. Them flower fellows is mighty sharp sometimes."

All the time I walked rapidly on towards the depot; but Mr. McTernan quickened his pace, and kept by my side.

Oh dear, he is, perhaps, very kind, but I do wish he would go away. But he would not, and after what he had said I had not the heart to be so rude as to ask him to leave me.

As we entered the depot, a great crowd of people came out of a newly arrived train, filling the whole building and streaming for the doors.

If this man would only go away. Here come plenty of my neighbors from the Centre. What will they think of me in the company of this man? If I only had my veil. I must give him the slip somehow. But it was of no use. He gravely escorted me to our train, and stood near the door for me to enter. I think I must have blushed scarlet, for it did seem as if everybody in our village hadchosen to come to town on that particular train. Quite vexed, I entered the car and took a seat in a dark corner, entirely ignoring my companion. He did not seem to notice it, but took a seat not far off, and, opening a paper, began to read. As for me, I was in a perfect rage at the whole affair. Will the cars never start? Shall I never get home, away from this hateful place? I declare I'll never sell another flower. I'll starve first. After a 
OR, HOW I BECAME A FLORIST.

while we did start. The motion and the changing scene turned the current of my thoughts, and I soon got over my pet.

Tuberoses! I declare, I can smell them now. How lovely they were! Wish I could grow them. I wonder whether he'll tell me if I ask him?. Without another thought, I boldly got up and went over and sat down in the next seat behind the man whom I had thought so rude.

"If you please, Mr. McTernan, I wish to ask your pardon - "

"Pardon, ma'am! for what? I was only telling ye for your own good. You see, this is the way he does it," and taking from his pocket a slip of paper, he handed it to me. This is a copy of it:-

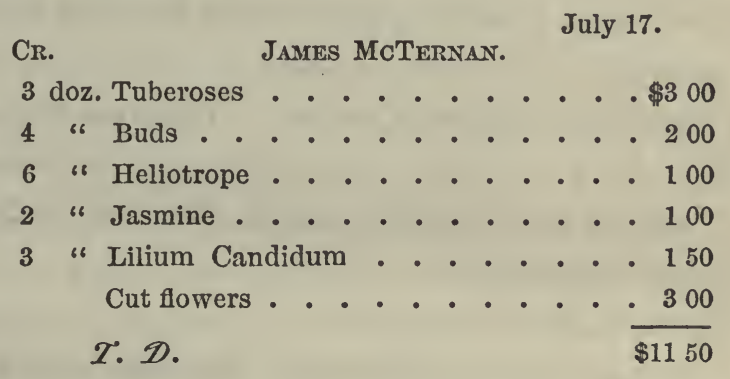

"That is my bill. I brought those flowers in this morning, and that's what I got for them. Thomas puts his mark on it, and then I shows it to Jane. She's the clerk. You see they pay us by the dozen, so much for each sort. 'I'm getting, as ye see, one dollar a dozen for my tubes. Now, 
if ye had counted the flowers ye brought in, ye would have got more for them."

"Why, Mr. McTernan, you are indeed kind." I am greatly obliged to you for telling me this. It is very good in you. I had not expected such kindness from a perfect stranger."

"Oh, never ye mind ; I likes to help folks if I can."

"Now, I have one favor more to ask, Mr. MeTernan. Tell me about the tubes, as you call them. How do you grow them? They must be valuable to command a dollar a dozen."

"Yes, they is a paying flower. They aint always worth that. In the fall they get down to fifty cents. Grow'em ? $\mathrm{Oh}$, it's easy enough. I pots them in five inch and plunges them. When they show a stem I gives a shift and tie 'em up."

"Thank you. I must try a few. Where can I get some seeds?"

"Seed, ma'am? They isn't a seed. It's a bulb. Thomas Dacy has 'em for sale."

"Thomas Dacy, who is he?"

"The bouquet man at the store. He that buys all the flowers."

Just then the train slacked up, and, looking out of the window, I found that I was at home.

"Good-morning, Mr. McTernan."

"Good-morning, ma'am." 
Reaching the house, I found Mary standing at the gate with a folded paper in her hand.

"See, mother; father's paper has come."

"What paper, dear?"

"The 'Agriculturist.' I found it in our box at the postoffice. May I open it, mother ?"

"Yes, if you wish. But let us have some breakfast."

After eating our meal, and putting the house in order, I went to the garden to see if the shower of yesterday had done any harm. I found that it had; the beds I had raked so smooth, a few days since, were ploughed and torn up by the rain, and many of the plants were broken down by the wind. There were but very few flowers to bo seen. Most of them were soiled and faded. How fortunate I was in cutting them yesterday afternoon! Finding things in such a deplorable condition, I resolved to spend the day in repairing damages. Getting a rake from the tool-house, I began to rake over the beds and put things as near right as $I$ knew how.

All the while $I$ was so much interested in what $I$ was doing, that I paid no attention to where or how I began. Indeed, I never thought of getting out of sight; but boldly went to work in full view of all the passers in the village street. I had not been occupied long before I was aware of some one standing on the sidewalk, and looking over the fence at me. I say I was aware of it; for I was too busy. to stop to look up and see who it was. . 
Presently, whoever it was passed on. Soon some one else came up, paused, and stood looking at me. Then a third person joined the second, and stared over my fence. But I paid no heed to them, going on with my work as though there was no one there. Then the two ladies began to talk to each other. I could hear every word.

"Sad, isn't it?"

"Yes."

"They do say the blow was too much for her."

"She thinks her husband is coming home and wants his garden put to rights."

"What a pity! And the children too."

"Bad for them."

At length one of them spoke aloud, and said, "Goodmorning, Mrs. Gilman."

"Good-morning, good-morning," replied I, looking at the pair. "Good-morning, Mrs. Smith, good-morning, Mrs. Carter," - for those were the gossips' names.

"Fine day, is it not?"

"Yes."

"I say, Mrs. Gilman, have you any petunias in your garden?"

"No, I pulled them all up. They don't pay."

Upon which the two women exchanged a meaning glance, as much as to say, "It is true then."

"I don't think they are a profitable flower to raise." 
Then another meaning look, and, with a solemn shaking of heads, they departed, muttering to themselves :-

"How sad! How sad!"

As for me, I made a mock heroic flourish with my rake, and executed as profound a courtesy as I knew how. Then I stuck my rake up in the ground and made a speech at it. And this is the speech :-

"Yes, my dears, I thank you for the news. And you, too, Mrs. Jacques, for circulating the report. Insane am I? Quite mad! and all because I, a woman, choose to become a florist, and work in my garden. Insane, indeed! Well, my dears, I shall not change my plans to suit you. Perhaps if you knew how I am paid, you would like to be insane too."

It being very warm after dinner, I did not venture out, but decided to wait till the mid-day heat had passed off. Accordingly, I took my work and sat down to sew. Sewing being with me almost a mechanical occupation, my thoughts were free to wander where they would. And they did wander away to tuberoses. Then the tuberose is a bulb. He "pots in a five-inch, and plunges." A five-inch? What can he mean by a five-inch ? A five-inch pot, perhaps. If I remember rightly, I have heard my husband speak of two-inch and three-inch pots. Yes, that must be it. But "plunging," I never heard of that before. Just then, I glanced at a ragged newspaper on the floor. Picking it up, I discovered it to be "The American Agriculturist, for the Farm, Garden, and Household." Little Mary, in her eager- 
ness to get at the pictures, had torn it open, - hence its ragged condition. Now, here is a piece of good fortune; perhaps I can find just what I want in this. We subscribed for the paper last January, but as I was not until lately at all interested in agriculture, my husband and the children had been the only readers. I am sure, after the first number, I had never looked at it. Now I examined it with the greatest interest. But not a word could I find about "plunging" anything. Perhaps some other number may have something on this point. So I went to the book-case and dragged down the six preceding numbers, and, throwing my work one side, gave myself up to the search. My labor was all in vain; not a syllable about "plunging " plants or pots. Yet my labor was not fruitless altogether. I found a world of facts and hints about the cultivation of flowers that would prove of great value to me in my new profession. At last I gave up the search for "plunging," and prepared to go to work again in the garden. As I passed the bookcase on my way out, I paused and ran my eye over the titles. There it is; just what I want. "Rand's Flowers for the Parlor and Garden." Taking the book down and turning to page 198, I found a chapter on "The Culture of the Tuberose." .This I carefully read through twice. But, if Mr. McTernan was concise and obscure, Mrr. Rand was profuse and darker still. The whole chapter involved the knowledge of so many facts of which I was ignorant, that really I was but little wiser for reading it. 
Determined to master the subject, I went to work to study it out. The book began by saying that a hot-bed was necessary. Perhaps so; but I had no hot-bed, and I knew not how to make one. To be sure, another chapter informed me how to prepare one; but the whole process was quite beyond me. Then I came to the words, "Prepare seven-inch pots with the usual drainage." There I stopped. "Seven-inch pots and drainage." I declare I can make nothing of it all. I might guess what "plunging" meant, and I could understand how to tell a good bulb, if I saw it, and how much it should cost. I learned also that each bulb would produce from twenty to thirty flowers, after which it was valueless, and must be thrown away. So much for book-farming and the pursuit of knowledge under difficulties. I know what I will do, - I will attack Mr. McTernan, and make him tell me all about it in the minutest detail, till I fully understand the whole. By this time it was getting towards sundown, and I resolved to return to my raking. Going to the tool-room, I found the rake was gone. Well, this is pleasing, no tools to work with! Seeing Johnny near, I asked him if he had seen the rake anywhere.

\section{"Yes, Uncle Joseph came in and took it."}

Now, I have no objection to lending tools, but I should like to be consulted first. Having no rake, I could do nothing; so I went back to the tool-room to inspect my stock in that line. If I am going to be a gardener, I must have suitable tools, and everything in good order. The tool- 
room was a small closet in our wood-shed. Since my husband's death it had hardly been entered. Opening the door I found everything in the most perfect order, just as he had left it the day he was killed. The sight made me sad enough, but I had work to do, and must brush back the tears, and give my mind to the duty nearest me. Seeing things in such good condition, I then and there resolved it should always be so. Neatness and order should reign in my garden and work-shop, as in my own chamber. I always clung to this resolve, and to it $I$ owe a large measure of my after success. On examining the tools, I found I was the possessor of two spades, a shovel, two hoes, an iron and a wooden rake, and a garden line and reel, for marking out beds. In one corner was a wheelbarrow, and in another a pile of flower-pots of all sizes, neatly sorted and piled up in rows. These I was glad to see; perhaps I should want them by and by, if I should attempt tuberoses in pots. On a shelf overhead I discovered a small watering-pot, a trowel, and sundry papers of seeds. In a small box on the floor I found a variety of carpenter's tools. Seeing a rule among them, I took it out, and, going to the pile of pots, I took up one and measured the side of it from top to bottom; then another and another, but they seemed to be of all sorts and sizes. Then I measured one across the top. Ah, that is it! A seven-inch pot is a pot that measures seven inches from side to side, over the top. In this lame and roundabout way did I discover what a seven or eight inch pot 
was. Delighted to find myself so well furnished for my new profession, I locked the door and put the key in my pocket, determined that if people wished to borrow they must come to me first.

Wandering out to the garden again, I walked along till I came to the bed of mignonnette I had planted the week before. To my delight, I found the ground entirely covered with the young plants just breaking through the soil. They were very thick, and formed a perfect mat over the whole surface. But is this right? Should they be so thick? Turning towards the house, I went into the sitting-room, and, taking up the book I had thrown down in such disgust a short time before, began to search through the index for mignonnette.

There was not a word about it. Finding a chapter on "The Garden," I looked that through, but though I found plenty of information on various other matters of importance, there was nothing in regard to mignonnette. Under the head of "Hardy Annuals" I found something about it, but nothing to help me. However, I found on the next page these words: "If the plants come up very thick, thin out the weakest; you will thus give room for the others, and secure a larger and a better bloom." Shuting the book, I prepared to put the information to immediate use. But it was too late. Going to the door, I found the twilight just fading away, and darkness prevented further efforts that day. 


\section{CHAPTER III.}

TAKING LESSONS IN FLORICULTURE.

ON finding; the next morning, that my rake had not been returned, I went over to my brother's to look for it. Meeting Joseph at the gate, I asked him if he had borrowed my rake.

"Yes."

"Well, where is it? for I wish it."

"I suppose it is lying round somewhere, - among the peas perhaps."

Going into the kitchen-garden, I found the rake lying on the grass, rusty and the worse for wear. Picking it up, I marched home, resolved, that if people who borrowed tools were so careless as to leave them out on the open ground all night, they could not borrow again. The remainder of that morning I worked in the garden as industriously as I could, and had the satisfaction, at noon, of seeing my garden again in nice order. After dinner I attacked the mignonette bed. It was terribly hard work, but, with the assistance of the children, when they returned from school, we accomplished the undertaking, leaving the plants standing about six inches apart, every way.

That evening I cut all the flowers I could find, sorted 
them, and laid them on the kitchen-table, and with a slip of paper and a pencil I made a list of the flowers, as far as I knew their names, with the number of dozens of each sort. The next morning I was at the depot, bright and early. On entering the cars, I looked about for my Mr. McTernan, and, finding him readily, I bade him "Good-morning," and took a seat near by. After a while I ventured to take out my list, and asked if he would be so kind as to tell me what such a list of flowerś would be worth.

"That depends, ma'am, whether they are first-class or not, . - if they aint first-class they aint worth anything."

"Look at them," said I, "and tell me."

Carefully turning over the contents of my box, he looked at them a while, then said, laconically, "Them's good enough!"

Delighted to find that my flowers were up to the marketstandard, I ventured to ask one more favor of him.

"Would Mr. McTernan please fill out the price on my list, so that I might know what they were really worth in the market?"

Putting on an old pair of silver-bowed spectacles, he studied the list for a few moments and then handed it back to me, saying, "I'll tell ye the price, but ye must write it yourself ; my hands aint used to writing."

So I took out my pencil, and, while the train stopped at a way-station, hastily wrote down the figures he gave me.

When it was done, it read somewhat in this way:- 


$$
\begin{aligned}
& 6 \text { doz. Heliotropes, . . . . } \$ 100 \\
& 4 \text { " Roses, . . . . . } 100 \\
& \frac{1}{2} \text { " Tea-roses, . . . . . } 37 \\
& 1 \text { “ Liliums, . . . . . } 75 \\
& \text { Cut flowers, . . . . } 100
\end{aligned}
$$

The cut flowers consisted of a number of varieties. Mr. McTernan said he should "lump" those, and call them "cut flowers."

After placing my flowers on the counter in the store, I quietly handed my list to the young man, Thomas. He looked at it for a moment, and then very significantly at me. I busied myself in tying up my box, preparatory to going home. Directly he went into a brown study over my list. Not knowing how long this would last, I moved as if to go. Upon which he woke up, scratched something upon the paper, and, handing it to me, said:-

"Show it to the book-keeper."

"Thank you, Mr. Thomas," I said to myself, "I fancy I am quite up to you this time. Thanks to Mr. McTernan, I know the value of flowers as well as you ; " and I marched off triumphantly towards the book-keeper's desk.

When I reached the desk, I was obliged to wait a moment, as the book-keeper was talking with a gentleman. While waiting thus I had an opportunity to have a good look at her, and I found her a young lady, small, plainly dressed in black, with delicate hands, and a face at once pleasant, cheerful, and just a grain pretty. Seated behind her handsome walnut desk, with the huge ledger spread out before 
her, she made quite a charming picture. When she had finished her business, she turned to me and held out her hand for my paper. Taking it, she looked at it a moment, and then said : -

"What name?"

"Gilman."

"Does Mr. Gilman keep a private place?"

"Mr. Gilman? There is no Mr. Gilman," said I, endeavoring to be as calm as possible.

"Excuse me. Does Miss or Mrs. Gilman keep the house?"

"Keep the house? Why, I am Mrs. Gilman." Of course, I keep my own house."

"Yes, but is it a private or a commercial house?"

"Really, I do not understand you at all." Then she explained to me that all greenhouses are divided into private or commercial. The private houses belong to people who follow some other occupation, or, being wealthy, keep a greenhouse for their own pleasure, and, having more flowers than they can use themselves, sell a portion in the market. The commercial houses are owned by the florists proper; who make it their business to grow flowers, and do nothing else.

Comprehending the distinction, I said that my place was a commercial one.

"Where is your greenhouse?"

"I have only a garden, - no greenhouse as yet. I am a widow, and live at the Centre." 
Finding also that she desired to know more, I gave her my whole story up to that time.

"Indeed, Mrs. Gilman, I am greatly interested in what you say, and can but applaud what you propose to do. The only wonder to me is that some one has not tried this before. Perhaps I can be of use to you in some direction. Now, is there any way in which I can help you? I know very little about raising flowers, but I can assist you as far as selling them is concerned."

"Thank you, you are very kind. Doubtless you will be able to help me often. Yes, you can do so now."

"That is pleasant. What is it?"

"Tell me about tuberoses. Does it pay to grow them? how long does it take to get them to flower? and where can I buy them?"

"One thing at a time. First, I suppose it does pay, for they all grow them. They bloom in ninety days, I think; and we have them for sale. But I am afraid you are too late, this year. In ninety days we must expect frosty weather, and, unless you have a greenhouse to put them in, you had better not attempt it this season. You will soon learn in gardening that, if a thing is not done at just such a time, it cannot be done again for a whole year."

"Perhaps I can keep them in my dining-room window." The young lady smiled at my query, and said she had never heard of such a thing, but that it might be worth trying on a small scale. 
"Johnny, bring me some tubes."

Johnny dived downstairs, and soon returned with a small quantity of curious-looking bulbs, quite dry and dusty.

"That's all there are left, miss. Only twenty in all."

"What is the price?" asked I.

"A dollar and a half a dozen. But, as you are in the trade, we will take off something. You may have the lot for a dollar."

I decided to take them, and Johnny turned them into my box.

Then, placing my name and the date at the top of my paper, she made a note of it, and, handing it to me with a smile, began turning the leaves of her book. Bidding her good-morning, I took my bill and departed, thankful and happy; happy in meeting with success in my morning's sale, and thankful in finding such a friend as Miss Sampson, the book-keeper, bid fair to be.

As I walked away, I passed a large dry goods store, with the shutters still up. Glancing at the door to see what it could mean, I saw a placard on the glass : "Taking Stock. Open next Monday." Now, there is an idea for me. Those business-men are taking an account of stock. I am a business woman and should follow their example. I'll do so before I go deeper into the business. But how about the money this morning? All I have is my list of flowers. What is that worth? I can't sell it, what shall I do? Will it ever be good for anything? Will they cash it at the 
store? Not a very business-like proceeding on my part after all. I'll go back and see about it. No, I'll consult Mr. McTernan. Finding him in the car, I asked what I should do with my list.

"Keep it, and, at the end of the month, they will give a check for it."

"Next, if you please, Mr. McTernan, I would like to know more about tubes."

"Well, ma'am, I am planting some this afternoon, and, if ye come to my place, at Maple Hill, ye'll see it done. My place is near the depot. Anybody will tell ye when ye get from the cars."

"Thank you, I must try to be there."

Just as I was leaving the cars, when we reached the Centre, I met Joseph.

"Good-morning, Maria, I was just looking for you."

"Well, what is it?"

"I have found a man who would like to buy your house."

"But I.do not intend to sell; I prefer to keep it for the present."

"Keep your house? Why, how can you stand the expense?"

"That's a question I hope to decide in time. Perhaps Providence will help me if I help myself."

"Stuff and nonsense, Maria. I don't wonder people talk about you as they do." 
To this I paid no heed, but turned towards home.

"Stop a moment, Maria. Now be sensible for once. How are you going to support yourself and your children in this house?".

"By the labor of my two hands."

" $O$ h, that's all very well, but $I$ am afraid you will find it pretty poor pickings. What can a woman do?"

"Joseph," I cried, "if Mr. Gilman were alive, you would not dare to say this. I'll thank you to say no more. I can, and shall, take care of myself."

Upon which he left me, muttering something about the fools not being all dead. I quite agreed with him.

That morning I spent at my housework. To tell the truth, this had been sadly neglected for the previous week. By dinner-time everything was finished up square, and all the threads gathered together and ready to go on again as smoothly as ever.

After clearing away the dinner things, I told the children that, as they had a half holiday, we would all go out for a walk over Maple Hill. It was my intention to visit Mr. McTernan's place, and see what information I could pick up in regard to tuberoses or anything else. At first, I thought of going up in the train; but the fares for us all would be, at least, thirty cents. Only a trifle, to be sure; but then it would not take many such trifles to use up my daily receipts. So off we started on our two-mile tramp, the children happy and gay as possible, ready to see and 
enjoy everything, and I quiet and at peace with everybody. Hopeful for the future, and encouraged by the fortunate turn my affairs had taken in the past few days, I found myself fully alive to all the beauty and charm of the day and scenery, and with a sense of freedom and perfect health I had never known before. On leaving the village, and getting into the open country, I involuntarily glanced at the blue sky. All was clear and bright, and not a cloud to be seen, save in the far south-west, where a thin, gauze-like cloud streamed upward and outward over the wooded hills, in shape like a fan. In the east a low, brown bank of smoke from the city drifted up the valley, where the river courses to the sea. What does that mean? I said to myself. Not a storm, I hope. It was strange how quickly I had become apprehensive of the weather, and how keenly I had learned to watch for a change. Talking with the children, and admiring the lovely views on every hand, and feasting upon the wild raspberries by the roadside, we found ourselves entering Maple Hill village much sooner than we expected. Ours was a short and pleasant walk, and short because it was pleasant.

On reaching Mr. McTernan's we entered his gate, and in a moment found ourselves in a perfect wilderness of flowers, drawn up in solid and orderly ranks, spread out in glowing masses, here, there, and everywhere. Huge beds of dazzling scarlet, great clouds of white, all colors and shades, mingled in charming confusion. Roso-bods literally 
glowing with color, and asters as thick as herd's grass, waved in the breeze like a field of wheat. Well, I don't wonder he can cut ten dollars a day from such a garden. Oh, I wish I was not so mercenary! Thinking of money as soon as $\mathrm{I}$ enter a garden like this.

Seeing a man at work we approached him, and found him busily at work making a row of small holes in the earth. "For what purpose do you design those holes?" I ventured to ask.

"Plunging, ma'am."

Not being much the wiser for this, I was about to question him further, but he appeared to be so uncommunicative, that I merely said:-

"Where is Mr. McTernan?"

"Yonder, in the shed. Walk right in the door ye see standing open next the greenus."

Sending the children to search out new wonders among the flowers, I entered the door as directed.

The sight that met my view was not a pleasant one at first, and I am afraid I showed my disappointment in my face. There stood my honest acquaintance before a rude bench, on which was a huge pile of dirt. He was roughly dressed, with his sleeves rolled up, and eagerly plunging his bare hands and arms through and through the heap of loam before him.

"Good-afternoon, ma'am. Clean dirt, marm," - then a dig at the pile. "Just in time, ma'am," - another plunge. 
"Just going to pot 'em. This is the stuff, - clean - fine - and - rich as butter." Another dive, another, and then a good slapping together of his hands, to shake off the soil. Hastily brushing a seat with his apron, he offered it to me, saying:-

"Take a seat, and you shall see the whole thing in a jiffy."

Thanking him, I sat down, not quite at my ease, however, in such a scene.

"Now, if you watch me, ye'll learn by seeing in half the time I'd be telling ye."

So saying, he took up a clean new flower-pot, and, taking from a box near by a handful of broken pots pounded up fine, he threw it into the pot, filling it about an inch deep. He then filled the pot nearly full of soil from the heap. Taking a bulb from a basket and holding it upright with one hand in the soil in the pot, he filled up the remainder of the pot with the other hand. Giving the pot a gentle rap on the bench, he set it on one side; going through the same operation, he next finished another. Quickening his motions, he began to do them very fast. Becoming interested in the ease and rapidity with which he worked, I left my seat, and came and stood close to the bench. Soon the rows of pots grew to a goodly size, and the busy workman stopped, and said: -

"There, ye see the whole story so far. After they have been watered the man will plunge them, up to the rim of 
the pot, in the ground, and in about a month they will be taken up, shifted into the next size pot, and plunged again. If they are very tall, I stick a stake in the pot and tie 'em to it to keep the wind from breaking them off. They's very tender."

"Yes, I think I understand it all now, except the shifting."

"Shifting is taking a plant out of one size pot, and putting it into the next size."

"Why, there is nothing difficult in that."

"No, it's dreadful easy when ye know how."

Just at this moment the door, that had been standing open, suddenly swung to with a loud slam.

"Wind's changed! East, I guess. Going to have a storm to-morrow. I knew it would be east soon; I saw the wind coming up the river awhile since."

"Saw the wind?"

"Yes; didn't ye see it as ye came along? the smoke from the chimblies was a-going for it. But wait a bit, till I shut up."

Upon this, he opened another door and stepped into the greenhouse. Presently he returned, and said:-

"Will ye see me take off the air?"

Wondering what that might be, I followed him to the greenhouse.

"Now, ye see them ventilators up there; well, they are open to let out the heat, but the wind has changed, and 
these plants won't stand east wind; so I takes off the air in this way ; "and, going to a large iron wheel fastened upon the wall, he began to turn it round by a handle affixed to the side. Instantly every window in the roof began to close, and soon they were all shut.

"Why, I could do that. Please let me try;" and I did, opening and closing them with the greatest ease, by merely turning the crank.

Now that is a revelation. . As far as ventilation is concerned, I could conduct a greenhouse as well as a man.

Returning to his shed, he began his potting again. Suddenly he stopped, and without a word went out of doors.

Now's my chance. I'll try it myself. Throwing back my shawl, I boldly thrust my ungloved hand into the heap of soil. How odd! I expected to find it very dirty and disagreeable. On the contrary, it's rather nice. Seizing a pot and a bulb, I potted it, going through all the motions to the final rap on the bench. "There, I fancy that's even better than he can do it, for my hands are not so rough and leave the work looking much nicer. Really, this-is much pleasanter than mixing dough or sewing on slop-work." Hearing some one coming, I hastily shook my hands, when, to my surprise, every trace of the soil came off, and they were as clean as ever. When Mr. 
McTernan opened the door, he saw what I had been doing, and, breaking out into a loud laugh, said :-

"Well, ye are a smart un, aint ye?"

Finding the sun going down, I called the children and, bidding him good-night, we started for home. A great change had come over things by this time. A cool east wind was ablowing, and all the western sky was overcast. We reached home tired, hungry, and in excellent spirits. 


\section{CHAPTER IV.}

TAKING STOCK.

THE next morning opened with a dull, cold, easterly storm. As I could do nothing out of doors, I spent the morning at housework. After dinner I took pen and paper to carry out my intention of taking an account of stock. First, I made a list of the tools; then, going to the book-case, I, took down all the books I could find on the subject of gardening; these I also considered as tools and aids in my new profession. The books had been purchased by my husband at different times; but, to tell the truth, I had never examined them, not being interested in that direction. The first book I took up was "The Fruit Garden," by Mr. Barry, of Rochester, N. Y. This did not strike me as being anything of value to me in regard to flowers; yet perhaps the general principles of the book might be valuable; so I laid it aside for future reference. Then I opened "Country Life; a Hand-book of Agriculture, Horticulture, and Landscape Gardening," by R. Morris Copeland. This seemed to me to be just what I wanted. I next found an old copy of "Breck's Book of Flowers," and these, with Rand's "Flowers for the Parlor and Garden," made up my library. I ought to include 
also an odd volume of "The Gardener's Monthly," and six numbers of "The American Agriculturist." As the rain continued to fall, I did not venture into the garden to make a list of the stock of growing plants out of doors; but. opening my husband's desk, searched through his papers for any bills of plants he might have purchased for the garden, as the bills would show the original cost of my plants. I found quite a number of them, but could not make out all the details; indeed, to be honest, I did not know the names of all the flowers I had in my grounds. For instance, hybrid perpetual roses were entered at four dollars a dozen, and tea roses at the same price. But what the difference was, I could not understand. So the bills helped me but little as far as the prices were concerned. Some things I understood readily, - such as heliotrope, which was put down at a dollar and a half per dozen. Taking this as a starting point, I could easily arrive at the cost and then estimate the probable return from the four dozen heliotrope plants in my possession. They cost six dollars. I had cut already at least one dozen flowers, nine different days. This, at a shilling a dozen, would be nine dollars, leaving me three dollars for the labor already spent in their cultivation. How much I might expect to cut for the remainder of the summer was more than I could guess; yet I felt safe in estimating a return of three dollars a week until the frost should destroy them in the fall. Thus it was plain, if I could make all my flowers pay at this rate, 
the whole question of my support was settled for the next two months. What I might do after that, when the winter came, was a question to be answered by and by. I was not so foolish as to think that I could make all the flowers yield such a return, yet, if one-half of them did as well, it was safe to go on with my new pursuit. Truly can I say, I nad abundant reason to be contented and thankful with my condition and prospects.

The storm continued all that night and the greater part of the next day. Towards evening the rain ceased, and, putting on an old straw hat, I ventured into the garden among the still dripping plants. I was apprehensive I should not be able to cut any flowers. Many of the plants were soiled and broken, yet I gathered a box full, and, carrying them to the house, dipped them, one at a time, in clean water, to remove the dirt. This operation I found injurious to some of them. The geraniums were quite spoiled, but the foliage and petals of the others seemed to be the better for the bath.

The next morning I was complimented on the nice appearance of my flowers by Thomas. He endorsed my list, and, after showing it to Miss Sampson, I returned home.

Having finished my household duties, I turned my-attention to the subject of tuberoses. Going into the woodshed, I procured two empty flour barrels, and placed them side by side near the window. Getting some pieces of board, a 
few nails, and a hammer, I managed to construct with my own hands my first potting bench. It was a sorry-looking affair, but would answer my purpose quite as well as if $\complement$ had ordered a carpenter to make it, at an expense which I could not afford. One thing I was determined to avoid, and that was debt. By making my own bench, as I have described, I steered clear of this rock, on which so many are wrecked. Next, getting a coal-hod and a spade, I procured the richest soil I could find in my garden, and in an hour had the satisfaction of seeing my tuberoses potted, plunged, and in order.

The following morning I was up in good season, resolved to finish taking an account of stock before the heat became oppressive. My garden was at one side of the house, and extended along the street for ten rods. The width was about seventy-five feet. The ground was not cut up with walks; a single narrow path ran through the middle, leaving almost the entire space for cultivation. The plants were set out in solid rows, filling the whole ground from one end to the other. All the plants of a sort were placed by themselves. First came the roses, of all kinds, planted in regular ranks; then my four dozen heliotropes, then a quantity of lilium candidum, as Mr. McTernan called them. Adjoining was a broad strip of verbenas, and next a bed of mignonnette. Beyond were several rows of white flowers, - feverfews, I supposed, - several also of double gillyflowers, a row of geraniums, some ranks of larkspur, six full rows of 
pinks (carnations, I think Thomas called them), and two rows of salvias, not yet in flower. A row of asters, just showing their buds, three rows of useless marigolds, then my new lot of mignonnette, and lastly, next the fence, fuchsias. Such, with a portion which I could not name, was my stock in trade. On consulting the bills I found the whole lot of plants had been purchased the spring before at a total cost of about seventy-five dollars. My tools and books I valued at fifteen dollars, and I entered the whole at an appraisal of ninety dollars accordingly.

Not finding anything further requiring attention out of doors I returned to my mending. That being soon finished I took my books again. Perhaps I can find something in them that will be of use to me. Opening Mr. Copeland's "Country Life," I found that the arrangement of the chapters was just what I needed. Each month all the important operations on the farm, in the greenhouse or flower garden, were taken up and discussed, so that I should know in advance what was to be done throughout the year. As July was nearly over, I turned to the seventy-seventh chapter on the garden in August; and there I read these words : "If you would have the full mid-summer glory in your flower garden be constant and careful in your attendance upon it." That's just the point.

I must follow it up carefully, and keep things in perfect order. Having finished the chapter, I turned to. "Hints about Work" in the August number of "The Gardener's 
Monthly," and in the newly arrived "Agriculturist," to learn what my duties would be for that month, now so soon to overtake me; and, to be frank, at first I was fairly bewildered and discouraged. Such an overwhelming amount of work to be done! I was in despair at the prospect. If my garden requires all this attention I may as well give it up at once. How could I ever expect to get through with such an immense amount of work? Quite disappointed to think I had embarked on such a laborious undertaking, I ventured out of doors to see if it were possible that there was so much to be done, and to consider whether I had not better abandon the whole project. Walking slowly along the path, I examined every plant to discover what ought to be done first, or, if anything should be done at all. Just as I reached the fuchsias I was startled by the sound of a voice from near the fence.

"Evening, Miss Gilman!" Looking up I discovered Mrs. Jacques peering over the fence at me.

"Good evening, Mrs. Jacques," I replied.

"What on airth are you doing in your garden? If I should go puttering round all day like that, my man would say I was an old fool!"

"I suppose he would," said I.

"Yes, he would, and rightly too!"

"Doubtless."

"Come now, what are you doing all day among the posies?" 
"Gardening, for my support."

"Gardening for a living? You don't say so. How much do you get?"

"That depends upon the kind of flowers I raise."

This somewhat confused her; after a pause she returned to the charge.

"Do you make it pay, Mrs. Gilman? My man says farming never will pay."

A little provoked with the woman, I replied that I thought he might be a good authority on the point, for I had never heard that he made anything pay.

"Pay or no, he aint such a fool as to stand round in a flower garden, all day, anyhow!"

"I suppose not. It is so much more manly 'standing round all day,' with a yard-stick in one hand and a pair of scissors in the other."

This shot told, for with a flout she disappeared. Turning towards the house I was surprised to discover a nicely dressed young gentleman standing in the path just before me, apparently very much taken up with my pinks. He was tall, well made, with a full-bearded face, that indicated at once good sense, education, and refinement. When he had finished examining the pinks, he came towards me, and taking off his hat very politely said, "Pardon the intrusion, but seeing your plants in nursery rows and in such perfect order, I guessed it must be a sales-place, and ventured in. Am I right?" 
"Yes, more than right. I do sell flowers, and you are free to examine if you wish."

"You have some fine carnations, and they are in good order." "Are they? I am glad to hear it."

"And your hybrid roses, too, are blooming very late. They are generally gone before this. Your garden evidently belongs to a gardener."

"It was my husband's garden. He is dead now. Since he died I have taken care of it myself."

"Indeed! and you sell the flowers too?"

"Yes, I am my own gardener, saleswoman, and everything else."

"Really, I am glad to hear it. I have long had an idea that women could become florists, as well as men. I am myself a florist, and as we are of one trade let me introduce myself. Edwin Felix. My greenhouses are on the turnpike, about two miles from here."

"Thank you, sir. I am pleased to make your acquaintance. But do not consider, or call me, a florist. I know absolutely nothing about it. Not nearly so much as did my husband, Mr. Gilman."

"Doubtless you can soon learn. Have you read any books on the subject?"

"I have merely glanced at one or two, but they tell me so many things $I \mathrm{am}$ in despair at the prospect. I do not know where to begin."

"I can understand your case. The books are important, 
yet it is only out-door practice that will make your reading of value. May I venture to tell you what to do first?"

"Certainly.",

"You see these roses are divided into two sorts. These, having thick, rough leaves, are hybrid perpetuals. They are not quite perpetual in this country, yet with care you can get a second crop in September. You see there are no buds left, only full-blown roses. When these are gone there will be no more unless you cut them down with a sharp knife." So saying, he took out his knife and cut off a fine rose, stem and all. "It is better to cut them thus. It exhausts the plant more to bloom one full rose than to grow six buds. Besides, a new growth will start, and more flowers follow. The more flowers you cut the more you will have. This applies to almost all flowers. All plants seem determined to produce a certain quantity of flowers. If unmolested, they will perfect the flowers and then stop. If the flowers are removed, the plant at once sets to work to replace them. If they are again removed, it makes still another effort. I would not advise the culture of the hybrids for profit. The tea roses are the only true perpetuals."

To this I listened with the closest attention, eager to learn all I could. Then, turning to the pinks, he pointed out how they should be tied up to stakes to prevent them falling to the ground. This, with weeding and keeping the soil open, was all that my garden required at present.

"Do not be discouraged, Mrs. Gilman. Persevere, and 
you will be sure to prosper. When I pass this way again, I will tell you what to do next." So saying, he departed.

Here, then, is another friend! Providence is certainly lending me a helping hand.

No sooner, however, was one difficulty settled, when another came up. What should I do about money matters? The cards I received from the flower store would not pay Mr. Hardtack the grocer, nor would Sharpedge \& Co. give me meat for them. I do not mean to run into debt; indeed, I must not. Could I forget Mrs. Warren's experience in "How I managed my house on $£ 200$ a year"? Her opening chapter made too deep an impression on me, to leave me easy under debt. Yet, for all that, I had to yield. My children must be fed, and to be able to work in my garden I must have good, substantial food. The final result was my obtaining credit at the stores till the end of the month. When that time arrived, I presented all my tickets or checks, and was paid promptly in full. That very morning I settled every bill, and had something left besides.

My whole income from the sale of flowers (including the fifteen dollars I mentioned before) amounted to forty-five dollars and fifty cents. By economy and care, we managed to live on a trifle less than this. To be sure, we had no rent to pay, and no repairs were needed at present. I had the interest on the mortgage and the taxes to pay, but"neither were due till December. Perhaps by that time I shall be able to meet them. 


\section{CHAPTER V.}

\section{A LONG LOOK AHEAD.}

The month of August passed with very much the same record as July. My flowers continued to grow and bloom abundantly. They did not, however, yield me so much more money. Fifty dollars was all I received for the whole month. It was the dull season, I was told. Everybody in the country had their own flowers, and the city consumers were at the sea-side, or at the mountains. I kept my garden in perfect order all the time, and with but little labor. In fact, I had quite as much leisure as I had ever known. Once I visited Mr. Me'Ternan, gathering much useful information. Mr. Felix called again, and seemed to find me doing well enough to be left to myself till the first of September, when, he said, many things would require attention.

My doings, I found, had made a great stir in the village. All sorts of stories were afloat in regard to me. Some laughed at me, some pitied, and none helped me, save the two store-keepers and strangers I met in the way of business.

At the close of the first week of September, I felt the first chill of the coming winter. My thermometer at my front door fell one morning to forty degrees. Thereupon, I 
fell to thinking. Yes, I began to think. I had learned to think now. With my out-door life had come increased bodily and mental capacity. The fresh air had improved my physique, and work had calmed down my mind, and turned my thoughts to more cheerful subjects. This, too, ought to be added to the profits of my undertaking, for is not health worth more than money? But what am I to do now, about money itself? According to the thermometer, I have come within eight degrees of being without it. Let the glass fall to thirty-two degrees, and my incomefrom the garden is at an end. As soon as we have a frost I shall be utterly without means for the next eight months. I had anticipated this, but had not given it very serious attention. Something must be done, and quickly. I will consult the books. "The Gardener's Monthly" thought it high time to get ready for winter. "The Agriculturist" was in favor of taking things in hand early, and recommended removing tender plants to the house. Mr. Copeland informed me that the florist's year began with September. Now is the time to begin the year by gathering the plants together, preparatory to removing them to the greenhouse. That's it! They are all getting their greenhouses ready. And I have none! Suppose I build one? It is not to be thought of. It would cost several thousand dollars, and all I have is the two thousand dollars I received as the insurance on my husband's life. No, I must do something else. I must take in sewing, and struggle through the winter, until my flower garden 
will again make a return. Busy with the problem, I heard the bell ring, and, going to the door, found Mr. Felix on the steps.

"Excuse me, Mrs. Gilman, I am in a hurry. I wish some flowers to fill an order. Will you cut me some?"

"With pleasure," said I, and we both went to the garden. Taking out his knife he began to cut the tea-rose buds, saying, at the same time :-

"Please, Mrs. Gilman, cut me six dozen heliotrope."

We both worked rapidly, and in a few moments he placed three dozen buds with my heliotropes. Taking out his purse, he prepared to pay me.

"Six dozen heliotropes, at a shilling, will be one dollar, and the buds will be a dollar and a half," said I. .

"More than that, Mrs. Gilman," said he, with a smile. "The cool nights have sent the price of flowers up. Roses sell at a dollar a dozen, and heliotrope advanced to twentyfive cents to-day, - four dollars and a half." And, handing me that amount, he took the flowers and going to his carriage that stood at the gate drove rapidly away.

"There goes an honest man, and a gentleman," thought I. So the price of flowers has nearly doubled. The early frosts will soon kill off the garden-flowers, and then those who have greenhouses will control the market. In fact, only they will have any flowers to sell at all. I have supported myself by my garden for two months, earning nearly one hundred dollars, and now, in spite of all I can do, my income 
is at an end. And my mignonnette too, that will be destroyed also. It is paying me twenty cents.a day, and perhaps, tomorrow it will be dead. And my tuberoses also, what can I do with them? I can put them in my windows, but all I shall get for them will not support me for more than two weeks. And what then? Really I wish I had a greenhouse. Wonder what they do cost? I'll consult Mr. Rand on the point. Opening the book I read the entire first chapter. Then I shut the volume, and made up my mind on the spot, - I will build a greenhouse. The next thing was action. No time must be lost, if $I$ wished to have the house ready before winter set in. I cast about for authorities on the subject. The books I had read through long ago, and I had a very tolerable idea of the different styles of horticultural structures. Woman-like, I first consulted a woman, - Miss Sampson. She was at first frightened at the boldness of my schemes. Yet she gave me a helping hand, and advised my visiting some of the best greenhouses in the neighborhood, and see for myself their cost, and the advantages of the different patterns.

I followed her hint at once, and, taking the cars, went to Massawatamie Highlands, and in the course of the day visited three different establishments. The first consisted of two enormous lean-to houses, several hundred feet in length. (By a lean-to, I found they meant a house having but one sloping glass roof, facing the south, and with covered sheds on the north side.) On entering I found a broad walk, 
running the whole length of the building. Between the walk and the south wall was a long table containing plants in pots.

On the other side and against the north wall was a bank of wooden steps rising like broad stairs almost to the roof. This, also, was covered with plants in pots. Along the path ran a number of iron pipes. These, I guessed, were for heating the building in winter. After looking about a short time, and wondering at the great strength and weight of the building, I found the proprietor, and ventured to ask the cost of such a structure. "Ten thousand dollars, and not a cent less." I did not stay to put any more questions. That settled the whole matter for me. I must not even dream of greenhouses. But as long as I had come to Massawatamie I ventured to glance at the next place, although quite sure I could never indulge in building. This place, likewise, had large lean-to houses, and, in addition, a house with two glass roofs, one against the other. This, I learned, was called a span-roof. Inside, I found two walks, one on each side, with the steps, or stage, placed in the middle, and following the line of the roof. And here was another trouble for poor me. How could I ever get up and down those steep steps to cut the flowers or water and tend the plants? I could not do it. It was wholly out of the question. The cost of such a house, I was told, was thirty dollars a running foot. That is, if the house was fifty feet long, it would cost fifteen hundred dollars, without the heat- 
ing apparatus. This seemed more cheerful, but not enough so to warrant my erecting such a structure. The third place resembled the others, excepting that everything seemed cheaper and plainer. In this, too, I found the same alarmingly high stages, and as I watched a man at work upon them I felt sure I never should possess the strength or the steadiness required for such a position.

In the train home I met Mr. McTernan, and ventured to approach him on the subject I was interested in.

"Well, ma'am, they don't cost much, if ye builds 'em cheap. I gets a carpenter to build mine, and has 'em made kinder rough and cheap. They don't last as long, not more'n six years, but they does grow the flowers. I generally calculates to pay for 'em in two years, and when they tumbles down, I builds another. Come and see me, and I'll show ye all about 'em."

And I did so, the very next day. He showed me a house . one hundred feet long, and twelve feet wide, which, he said, cost, heating apparatus, stage, and all, about a thousand dollars. It was a rough affair indeed, very rude, if not shabby. Yet it was filled with flowers in the most vigorous and healthy condition.

"How much do you cut from such a building, Mr. Mc'Ternan?"

"Well, I gets about five dollars a day, take it all the year round, sometimes more, and sometimes nothing at all for a month." 
"You think it a profitable operation then?"

"Well, ma'am, I can't say as to that, - I aint very good at figgers, - but my greenhouse keeps me and my folks, and I always has a little money besides.; but, bless ye, I can't keep it, - I always was a spending money since I was a boy."

That afternoon, I visited Mr. Felix, and, laying before him the whole matter, asked his advice. When I had finished, he seemed lost in thought for a few moments, then starting up suddenly, went to the door and called to some one outside to put the horse in the carriage.

"Come," said he, returning to me. "Get in my carriage and I will drive you over to Warkau. There is a house there I think will meet your views."

I hesitated at firstabout accepting his kindness.

"Why, Mrs. Gilman, I am sure you will go. I merely wish to put you on the right road in your business."

"Thank you, sir, I will go with you."

After a short ride, we turned down a lane, and, half buried in the woods, found a collection of curiously contrived glass covers merely, as they seemed at first; very long, quite narrow, and one house placed beside another; the whole together having the appearance of immense waves, as if some great sea had its billows suddenly frozen stiff; literally a sea of glass.

"There," said Mr. Felix, "is the style of house that will be of use to you. Cheap, - adapted to many purposes, - and easily kept warm." 
"But I could not stand upright in such a low place. They are hardly three feet high in the centre."

"All that is provided for. Come and see."

So we got out, and walked through the garden towards a long shed that extended across the ends of all the houses. At the door I was introduced to the proprietor, Mr. Clockwell, a quiet, gentlemanly young man, plainly dressed as if about his work. Opening the door, he bade us enter, saying:-

"I shall be glad to show you everything, and give you whatever information you desire."

Inside the door, we passed down a few steps and found ourselves in a narrow, but very long shed, having windows on one side and a number of small doors on the other. Entering one of these, we were at once within a long and narrow building, with a pointed-glass roof overhead. A path extended through the centre, leaving just room to walk and not strike the roof with your head. On either side low tables, on which were placed growing plants in pots, ran along from end to end.

In another house the tables had board edging and were filled with soil in which plants were growing. In a third, instead of tables, a low bed of border of loam filled each side of the path, and in this taller plants were growing as in a garden. Everything was in the most perfect order, and all the plants looked bright and healthy.

"You see, Mrs. Gilman," said Mr. Felix, "the advantage 
of this pattern of house is that every plant is within easy reach. No climbing of lofty stages here. The labor of cultivation is greatly reduced. In fact it is quite fascinating to conduct such a house, so easy is it."

"But it must be a great undertaking to carry water in a watering-pot through these narrow walks, and for such great distances."

Mr. Clockwell smiled at this, and said that, with him, watering was no labor at all, rather amusing than otherwise. He never used a watering-pot. If we would like to see it done, we had only to come into another house. In the next building, which was filled with an immense number of small plants in pots, placed on tables, we found a long rubber hose stretched out on the floor. This Mr. Clockwell took up, and, calling to some one outside to let on the water, held the brass nozzle at the end of the hose over the plants. Immediately a fine spray of water rushed out, and spread over several dozen plants at once. In an instant they were well drenched, and, with a slight movement of the hand, the stream was diverted to other plants. I fairly laughed when I saw it.

"Could anything be more easy? Why, I could do that myself!"

"Try it."

And I did. Really it was a charming way of watering. Bidding Mr. Felix take out his watch and time my movements, I held the hose over the plants just sixty seconds. 
Then we counted the plants I had watered. They amounted to nearly five hundred.

"But where does the water come from?"

"It is pumped up in a tank on the roof of the shed to give it 'head' or force. I have only to turn it on, and away it goes, as you see. When I have finished one house, I drag the hose along to the next."

All these things and many more were shown to us, and, after spending an hour very pleasantly, Mr. Felix drove me home by another road. Just before we reached the gate, he said : -

"Now, Mrs. Gilman, if you really intend to build a greenhouse, you should be about it at once. We may have a frost any night."

"Yes, sir, I appreciate the necessity of haste, and must consult my carpenter at once in regard to the cost, - that point will decide the whole question."

"The cost of such houses as we have just seen is not great. Can I help you in any other particular?"

"Thank you, sir, you can indeed."

"Well, have yoür carpenter on hand to-morrow evening, and I will drop in and show him how to draw his plans and estimate the cost."

That very evening I went to Mr. Sawplane's shop, and said to him: -

"Mr. Sawplane, I propose to build a greenhouse. Will you please call at my house to-morrow evening about it?" 
He promised to do so. Bidding him good-night, I turned to leave, when who should I see but Mrs. Jacques. Wonder if she overheard what I said. It's just like her to be near and yet give no intimation of her presence.

The following evening was quite cool, and as I had some fears for my tuberoses, I took them up, washed the pots, and placed eighteen of them in my windows. Two of them had failed to throw up flower stems. These I put in the shed, intending to ask Mr. Felix what I should do with them.

About six Mr. Felix arrived.

"I have come early, Mrs. Gilman, as I wish to talk to you before you take further steps in the matter."

"I am all ears, - temporarily," said I, showing him to our sitting-room.

"There is one point I am afraid you have not taken into account in connection with your proposed greenhouse. It is the stock. The plants in your garden are not of the right sorts, nor is there enough of them."

"Yes, I have looked into that matter already. I turned to the books for information, and think ${ }^{\bullet} \mathrm{I}$ know about what I require and the probable cost."

"Yes, that is all very well, but the books tell too much. You must discriminate; you do not yet know the nature and wants of the hundred or more plants they mention. If you attempted tinem all you would fail. The most skilful gardeners would not succeed with them all if they tried. 
I, with all my experience, would not undertake to grow more than a dozen sorts. It is better for you to confine yourself to perhaps six varieties."

"Thank you, Mr. Felix. I understand you perfectly. What six shall I take? Would heliotrope do for one?"

"Admirably; the culture is easy and the return in flowers liberal."

Just then the bell rang and Mr. Sawplane entered. Introducing the two gentlemen to each other, they got out drawing materials, and Mr. Felix began to unfold his plans to the carpenter. I sat near by, an absorbed and interested listener. We had not been so engaged long, before the bell rang again, and, opening the door, I found my brother Joseph, his wife Charlotte, and Mr. Dooless, the minister. There was no help for it, and I asked them into the room where the two gentlemen were sitting. After introducing them to my visitors, I offered seats, and we all sat down. The usual remarks on the weather followed, and then conversation suddenly ceased, and a dreadful pause ensued. Anxious for a change, I turned to $\mathrm{Mr}$. Felix, and said:-

"How do you get on with your drawings?"

"Oh, - fairly, - thank you. I think Mr. Sawplane grasps my idea of a house, though it is a new one to him."

Here the minister coughed, and. his companions looked at each other with a peculiar smile. I paid no attention 
to them, but went on talking about the plans. Suddenly my brother broke silence.

"Sister, is it true then that you intend to build a greenhouse?"

"Yes, I had thought of it."

"Thanks again, Mrs. Jacques. I'll remember this." This to myself.

"But do you think it a wise plan? Is it not likely to prove a foolish waste of money?"

"I think not. It is designed to bring money, not sink it."

"Perhaps it is not designed to sink money, but it will; you, your money, house, and everything else."

"Remember your children," said Charlotte.

"I do, they are always in my thoughts. For them do I labor with my hands."

Then Mr. Dooless spoke. "Does your conscience approve of this plan, Mrs. Gilman?" .

"I never do what it does not, sir."

"But, sister, how do you ever expect to get back the money you embark in this scheme?"

"By selling the flowers I produce."

At this the minister gave a pitying smile, and Charlotte tossed up her pretty nose in scorn.

"Sell the flowers! How horrid! I'm ashamed of you, Maria."

"Are you, madam?" said Mr. Felix. "Some people think it an honorable employment." 
"No gentleman would, I am sure, and no lady can stoop so low."

"Ah, thank you for your opinion. Our tastes differ, I see."

"Come, Maria, say you will give up this wild scheme."

"No, Joseph, I had rather not. I have been so successful thus far that I do not intend to stop now. Having put my hand to the plough, I shall not turn back."

"Indeed! I should like to know how much you have made. Did it pay for your shoe leather?"

"I shall not tell you, Joseph. I never asked to see your ledger, and I'll not show you mine."

"Nobody cares to see it, I am sure," said Charlotte.

"Christian friends," said the minister, rising, "let us depart. 'Ephraim is joined to his idols.'"

"Yes," said I, "and means to stay joined."

Then they rose as if to go. I was glad and relieved, for the whole scene was annoying and painful. Just as they started for the door, Mr. Felix spoke.

"Wait a moment, gentlemen. Let us hear more of this matter. The other side has not been heard yet. Perhaps, after all, Mrs. Gilman could be induced to give us some of the facts in relation to her business. I, for one, could judge of them correctly, as I am a practical florist."

At this my sister literally wilted away, and endeavored to beat a retreat, but Joseph detained her. They then sat down again, but evidently in no pleasant mood. 
"Mrs. Gilman, will you be so kind as to give us the amount of your sales the past month ? The facts may help us in this difficulty:"

"Fifty dollars," I replied.

"And in July?"

"Forty-five and a half. While, already this month I have sold thirty-five dollars' worth, but this is owing to the increased price for flowers. My garden produces, however, no more this month than last."

"Fifty dollars a month," observed Joseph. "Why, that's more than I pay my clerk."

"And your expenses were - "

"Nothing but my fare in the cars, and a dollar and twenty cents I paid for bulbs and seeds."

"Nonsense, Maria, you must have had a man to take care of your plants."

"I did not, Joseph. All the work was done by my own hands."

"O Maria! how could you? I wonder you are not a perfect fright by this time."

"Do I look so, Charlotte?"

"Well, no, - not by lamplight."

"One more question, Mrs. Gilman, and I am done. Can you tell us how much the plants in your garden cost ? I think you said they were planted in the spring."

"Yes; I examined my husband's bills ond found he paid seventy-five dollars for the plants." 
"Seventy-five dollars? A great price. I would have sold him the lot for sixty. Now, gentlemen, you have heard the defendant in the case. What have you to say?"

They had nothing to say at all. A short pause ensued. and then Charlotte remembered she must hurry home to the baby, and the minister found he had another call to make that evening. I cheerfully ushered them to the door, and they departed into the night.

"Gentlemen, let us go on with our pląns. 


\section{CHAPTER VI.}

.HOUSE-BUILDING.

ON returning a few mornings after this from the city $I$ found my garden in possession of a large gang of laborers. The fence in front had been removed, a pile of lumber lay on the sidewalk, and some men were unloading a quantity of posts from a wagon that stood in the street. Fearing for my flowers I hastened to find the foreman, to warn him about my plants. He knew all about it; had taken them up and placed them in the cellar, safely covered up with damp soil. Changing my dress, I went out to watch the proceedings. In this I was not alone. From the time the first man came till they all drove away there was constantly a crowd of idlers, men and boys mainly, standing on the sidewalk, watching the operations. Them I at once and forever ignored.

The first thing done was to mark out a space on the ground one hundred and ten feet long, and twenty-one feet wide. This being done the whole gang of men began at once to dig up the soil enclosed in this space, and to throw it out on either side. There were so many of them the work progressed rapilly, and at noon the whole space was dug out to the depth of one foot. After dinner the men were divided into two parties. One party busied themselves in making holes 
along the edge of the pit they had excavated. The others set up in these short cedar posts. At evening the posts were all set, about six feet apart, around the entire space. These posts were sunk in the bottom of the pit and extended above the level ground about one foot. The next day being fair, the work went rapidly forward. At night the work presented this appearance; a portion of the pit, about ten feet wide by twenty long, had been sunk quite deep in the ground. At the west end nearest the house, in fact within ten feet of our dining-room window, stood the frame of a small shed, running the whole width of the excavation, and about ten feet wide. From end to end four feet from the posts the pit was sunk one foot deeper than the rest. Directly through the centre stood another row of posts similar to those on the outside. This may seem a great amount of work for two days, but I had instructed Mr. Sawplane to engage all the men he could find, and to do everything thoroughly, but at high pressure.

The next day I received a package and this letter by mail : -

"Allegan, September 20, -

"MrS. GILMaN :-Accompanying this are several wholesale trade catalogues of greenhouse stock. By examining them you can ascertain the price of the plants you will require for your new house. The following are the sorts I would recommend :-

Tea Roses.

Carnations.
Heliotrope.

Violets. 
Azaleas.

Epacris and Bouvardia.

Ericas (Heaths).

"These are standard greenhouse flowers. The roses will give you a succession of flowers through the late winter and spring months. The heliotrope, with care, can be made to bloom every day in the year. The carnations and violets will last about four months. The other kinds give but one crop in the year. As these do not all flower at once, you can cut one sort after another has gone, and so extend your income over a longer time. But to these I would add still another list, in order to extend your cutting season still farther. The plants I have mentioned will fill your houses, but that is not enough. You must have a reserved supply to bring in after these have gone out of flower. In order to do this all the plants on the following list must be stored in your house-cellar until you require them in January after the season turns. I will explain all this by and by. Here is the list :-

Deutzia Gracelis. Fuchsias.

Astilbe Japonica.

\section{Lilium Candidum.}

"To still further extend your sales, you can in the spring sow seeds of various annuals, stocks, pansies, etc., trifles in themselves, yet useful to piece out your income.

"Enclosed are letters of introduction to the parties whose catalogues I have sent you. If you purchase of them it may be of advantage to you to have it known that you are in the trade.

"There are many more flowers it would be profltable for you to grow, yet here is quite enough to begin with.

"All the plants you purchase must be short, not more than two feet high. You must not attempt camellias at all, unless you can flnd them very short, in which case they would bear so few flowers it would not be worth while.

"Leave the violets till the last. When you have enough of the others, fill up the remainder of the house with them.

"I do not think the cost will exceed flve hundred dollars in all. If 
it were May instead of September, they would not cost one half of this. As it is, you will have to pay the cost of the culture up to this time.

"Please inform me when the plants arrive and I will call and show you how to place them in your house.

"My object in sending you this letter is not to induce you to purchase of my colaborers, but because I am glad to help one who is so bravely carrying out what has long been a favorite idea of mine, that women have a right to any field of labor in which they are able and willing to work.

" Respectfully yours,

"Edwin Feirx."

Immediately on reading this I sat down and wrote a note to Mr. Felix, expressing my hearty thanks for his kindness, and promising to call at his place in a day or two and thank him personally.

At the rate at which my house progressed, it would be finished in ten days; so I set about getting my stock at once. On looking over the catalogues I found they all made specialities of certain classes of plants. One man had a great assortment of heaths, another had roses and carnations.

Selecting the rose and carnation man, I went to him first. His place was the other side of the city, on another railroad. On reaching the place, I presented my letter of introduction to the proprietor, and he conducted me to his counting-room at once. Giving me a seat, he said he would bring me some samples of his plants.

"My houses are not fit for a lady to enter. They are too 
low and narrow. I can show you our plants without the trouble of going over the house."

Now this did not suit me. I was in search of information as well as plants. I wanted to see how he grew them.

"Well, ma'am, if you are not afraid of a little dirt, you can come through my rose-house."

Opening a side-door, we went out, crossed a small yard, and entered a large span-roofed house. This building was without stages, but had all the roses planted out in the border or floor as in an out-door garden.

"That," said the man, pointing to a large and thrifty bush filled with long, almond-shaped rosebuds of a delicate straw or sulphur color, "is the sofrano. And that the bon silene," pointing to a blood-red rose-bud, similar in shape "These two roses are the best for your use. They are adapted to all kinds of flower-work. The sofrano is used both for funeral or wedding orders, and the bon silene is unrivalled for brilliancy of color. I can sell you plants of these two kinds one foot high and one year old, in pots, for thirty-five dollars a hundred. They are all in good order and some are showing flower."

"How many buds can I expect from each before next July?"

"Well, I couldn't say exactly. If they are well grown, you can cut from six to twenty buds in that time. If you only cut six, you will more than pay for the plants. Good sofrano buds are worth eight cents each in the winter." 
I said I would take one hundred of each, and then asked to see the carnations.

"I am sorry, ma'am, I can't let you have many carnations. I've sold about all I can spare. I require about ten thousand for my own use, and what few over that I have I must keep for my retail trade. Why do you not go to Mr. Felix? I heard him say he had fifteen thousand this year. He would sellyou some, without doubt."

After spending an hour in looking over the bewildering multitude of plants on the place, I ordered the plants sent to me in ten days with the bill, and went home. What struck me as remarkable in this place was the immense number of plants gathered together in one establishment. Ten thousand carnations and none to spare! I wonder if I shall ever conduct business on such a scale?

The next day I went up our own railroad about twenty miles to see the heath and epacris man. This place was quite small. The man devoted his entire attention to this class of plants, and had a great reputation as a heath man. His houses were all like Mr. Clockwell's, - long and half sunk in the ground. All the plants were in fine condition, short, bushy, and of a rich green color. A portion were in flower. I had never seen a more remarkable sight. There were five thousand in bloom, he informed me. I found the price was much higher than for roses, but was told that these plants were two years old and would last in good order for five years to come. I bought one hundred heaths and 
one hundred epacris, at fifty cents each. They were in pots and would not require shifting for six months or a year.

The following day I walked over to Mr. Felix's. After thanking him for his letter I asked to see his carnations. Showing the way through his grounds, we at last came upon an open field entirely filled with carnation plants growing closely together in long rows.

"What an enormous collection of plants! Where did you get so many?"

"Some I raised myself, and some I bought last spring."

"How many plants are there here, Mr. Felix?"

"About twelve thousand."

"Twelve thousand! How could you ever count them all ?"

"I never did. I only counted the plants in one row, and then counted the number of rows. It would take too long to count them all."

"They are coming into flower, - are they not?"

"Yes, they have about ten buds on each now. In the winter they will have about five times as many."

"What do you get for the flowers in the winter? if I may ask."

"You may ask what you please. I have no secrets about it. They are worth from two to four cents each."

"How much do you charge for the plants after they are taken up and potted?"

"They are not potted at all, - only taken up and planted 
in the borders in the house. You must do the same. You thereby save the expense of the pots and the labor of potting. I must charge you forty cents each for them. You had best not take a great many, but let it go till next year. In the spring you can have all you want for six cents each."

"I will take a hundred, at any rate. If the ten buds that are on them now bring four cents each, I shall get my money back."

"You will do more than that, I am sure." But come into the plant-house and see my heliotrope."

Going into the plant-house (which is the name of the style of house we had seen at Mr. Clockwell's, and also the style in which I was building my own), he showed me a quantity of young heliotrope plants in three-inch pots.

"These are quite small, in fact mere rooted cuttings; yet I advise you to take them. They will not flower so soon as larger ones, but you can have them very cheap, - not more than ten dollars a hundred, if you take several hundred. There are few flowers that will give you a better return. There are some larger ones in six-inch pots. They are just showing flower. They are worth sixteen dollars a hundred."

"Then I will compromise and take part of each, - one. hundred at sixteen and three hundred at ten dollars."

After again thanking him for his kindness, I started to walk to Mr. Clockwell's. I had brought some luncheon in my pocket, and, taking it out, ate it on the road as I walked along. A more delightful lunch I never had. The 
sun was shining brightly and the air was cool and crisp. The walking was good, and all nature seemed in her most sharming autumnal mood.

On reaching the place, I found Mr. Clockwell was not at home. Taking out my knife (I carried one always), I cut a stout stick from a bush and set out on my three-mile tramp homewards. Just before I entered the village I threw my cane away. My pride was not quite dead yet. I reached home just as the workmen were going away, tired and hungry from my five-mile walk. But what of that? A good supper and a night's rest would correct everything.

The next day was devoted to housework. Perhaps you wonder how I attended to this at all. In the first place, I had all my evenings to myself; secondly, my children helped me as far as they were able; and, lastly, we are not any of us "idlers in the land."

As I had some mending to do, I sat down by the window to watch the men at work on my new plant-house. The new shed was roofed over, doors and windows in, and all finished outside. A low stone wall had been built up between the posts extending around the cellar or pit. On top and firmly fastened to the posts was a narrow strip of twoinch plank having the top bevelled off at an angle of forty-five degrees. On top of the row of posts placed through the centre was a broad piece of plank having upright edges, so that it had the appearance of a long, narrow trough. This was also bevelled off like the top of the outside wall. Six 
feet from the bottom of the pit, and fastened up in a temporary manner, equidistant from the wall and the centre post, were two pieces of timber of a very peculiar shape. A drawing will best describe it.

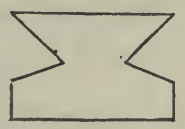

These were all the parts of the house completed, making a sort of skeleton. While I was studying all this out, two large teams drove up piled high with hot-bed sash, - as the farmers call them. They were plain sashes filled with glass six feet long by three wide, looking like exaggerated skylights. The workmen at once unloaded these and placed them in heaps in our yard. This done, they took up one sash, and, placing the bottom on the bevelled edge of the wall, dropped the top into the slot or groove in the ridge-pole, as you see in the drawing. Taking four screws they quickly fastened it down top and bottom. Then they put another on the opposite side so that the two sashes made an arch. Leaving a space the width of a sash, they put up two more, and then more, till half of all the sashes were in place. This done, the temporary supports were taken away and the building at once supported itself. Other men in the mean while had been fastening curious iron hooks to the wall opposite the spaces. They then took a sash, dropped the bottom in the iron hooks, and slid the whole thing neatly into place alongside the sash already in. In thirty minutes 
every sash was in place, and my plant-house was complete, except the inside. Delighted with the neat and compact appearance of the house, I went out to inspect. . At the door I met Mr. Felix.

"Allow me to congratulate you, Mrs. Gilman, on the appearance of your new house."

"Thank you, sir. Will you come and look at it?"

We then went to examine. It presented somewhat this appearance. First, a one-story shed with a door and two windows are towards the yard, and one looking south over the two glass roofs. These two roofs were placed side by side and extended to the limits of my garden, just one hundred feet. The street ran north and south, and the planthouse was parallel to it and about twenty feet from the sidewalk. You see the building occupied almost all my garden, but that was of no consequence, as I intended to farm under glass after this, and would not need so large a garden. In fact, my whole estate is very small. My whole place was only one hundred and sixty feet long and seventy-five wide. I called it my farm, and as the street front was just ten rods I gave it the name that heads this story.

After examining the improvements, I asked Mr. Felix into the house. On entering the sitting-room he went to the window to look at my tuberoses.

"Hardly a success, Mrs. Gilman."

"How so? I thought they were looking well and would bear a full crop of tuberoses." 
"They will produce some, but not half -a crop. The soil you used was too clayey. There was not enough sand in it."

"Indeed. My ignorance is my only excuse."

"Never be ashamed of your ignorance. I have made worse mistakes than that."

"Now, Mrs. Gilman, in this new undertaking you may make more serious mistakes than this, and would it not be a good idea to have some man like Mc'Ternan come here once a week and tell you what attention your plants require from week to week, and how to give it; in fact, give you a lesson in gardening. I do not imagine he would have to come a great many weeks. You are an apt scholar in all that pertains to flowers."

"Yes, I think I am quick to learn. But it is from the fact that by gardening I earn my livelihood."

"There is one other thing I wish to mention. I think you ought to "engage a lad to do the heavy work about your business. Building fires, pumping water, etc. Your income from the plant-house will fully warrant you in the expense. It is not important that he should know anything of plants. You must be your own gardener and instruct him, - not he you. It would be best to engage him before your plants arrive, as there is a great deal to be done to get the soil ready. If you will get a piece of paper I will write down a list of the soils you will require, and you had better order them at once. 
"Three cords of rich compost.

One cord of meadow muck, one year old.

Twenty loads of good loam.

Four loads of fine sand.

Two loads of rubble or small stones.

"Have them thrown up in separate heaps in the yard. and I will show you how to mix them when the time comes. The cost will be about fifty dollars. It may seem a great price to pay, but you can do nothing without it; and to offset it you will not have the expense of pots, as almost all your stock will be planted directly in the soil."

"Thank you, Mr. Felix. You help me out wonderfully. But I do not like to be under so much obligation to you."

"Never mind that. I am glad to help you, as you are so bravely trying to help yourself. Get your boy and the soils, and I will call next week." Saying this he took his hat as if to go.

"Wait a moment, Mr. Felix, I have one little favor "to ask. Why could you not come once a week and tell me more? Why cannot you be my teacher yourself?"

"Oh, don't ask me. My time is so valuable in the winter, I should have to charge five dollars an hour while I was here."

"I will pay it gladly if you will come whenever I wish. It will not be oftener than once a week."

"I will consider it, Mrs. Gilman, and see you next week. Good-night." 
"Good-night, sir."

In a few days I found a boy, Richard Dermand, by name, just out of school, knowing nothing of gardening, but willing to learn and able to work. By Wednesday of the following week, I had procured and paid for the various soils mentioned on the list I received from Mr. Felix. That evening Mr. Sawplane came and informed me that my plant-house was finished according to contract, and that nothing remained but to take the key and pay the bill.

The next day was the first of October. Since my building operations began, my income from the garden had ceased. My sales up to that time amounted to forty-three dollars. In all, I have received from my garden thus far, one hundred and thirty-eight dollars and fifty cents. 


\section{CHAPTER VII.}

\section{SUCCESS - FAILURE - SUCCESS AGAIN.}

LET me take you into my plant-house, now that it is finished. On entering the door we find ourselves in a small room, twenty feet long by ten wide. There are two windows, one looking on the front yard and one out over the two glass roofs. The floor extends over a portion of the shed; one end being sunk down into a cellar four feet deep. A few steps lead down to the "Hitching's Boiler" that heats the building. A coal-bin, a small force-pump with a coil of hose, and a spacious potting-bench, constitute the furniture of the place. Two short flights of steps lead down into the two plant-houses, for they are in reality two separate buildings, though the eaves of each come together on one side, forming a long valley. Entering the door of the right hand, - or west house, as I call it for the sake of a name, - we find ourselves under a glass roof in the form of an arch. The base of the arch is level with the ground outside. The ridge rises three feet higher than this, and the walk within is sunk three feet lower. This gives six feet for head room. Two rows of small posts, three feet high. and two feet apart, extend the whole length of the place. To these are nailed boards 
planed on the inside, or towards the walk. Thus we have left a narrow path, two feet wide through the centre of the house. On each side of this walk about a foot from the floor runs a four-inch iron pipe, which, when filled with hot water from the boiler, keeps the place warm in the winter. Outside the path is a long trough four feet wide and two feet deep. This is to be filled with soil, and in or on this soil the plants are to grow or stand in pots. When it is full this is called "the border." The second house is precisely like this, except that it is divided in the middle by a partition, having a door in it. That portion I call the east house; beyond, the violet house. At the entrance of each of these houses is a "cut-off" in the hot-water pipe, to regulate the heat. The borders in these three houses form my winter farm. Their united length is four hundred feet. In this space, four hundred feet by four, or sixteen hundred square feet, I expect to produce all the flowers I require in my business. Beneath the shed is a deep pit, having the sides plastered over with cement. The rain falling on the glass roofs runs into this, and supplies the water for my plants. Directly over the walks, and within easy reach, iron rachets are fastened to every other sash. These enabled me to tilt the sashes up for ventilation, or remove them altogether if wished. I did not adopt Mr. McTernan's method of opening the ventilators, partly because I had no high stage to climb, and partly because my plan was cheaper. 
Having thus described my plant-house, let me tell you how I stocked it. First I had my boy wheel all the rubble in his barrow up to the side of the house, and, taking out one of the loose sashes dump it into the bottom of the borders, spreading it out about six inches deep. Then I engaged a laborer to help the boy, and had the various heaps of sand, loam, etc., thrown up in one huge pile. This being done they began at one end, and turned it all over, breaking the lumps and mixing the whole well together. When this was accomplished the entire heap was removed in the wheelbarrow to the borders. When the work was completed the interior presented this appearance, - the right hand border in the west house filled up level with the boarding of the path; fifty feet on the other side filled in the same way, and the remaining fifty feet filled within twelve inches of the top. By so doing, I gained one foot in height for the taller plants. The border in the violet house was filled full. One half of the east house border was full, and one half one foot lower.

By this time the plants began to arrive. First came the roses. These, together with a few from my garden, I had planted in the left-hand border in the west house, giving them half the length of the house. The opposite border was devoted to the four hundred heliotropes. All of these were taken out of the pots, and planted in the soil of the border, just as we would treat them in the open ground in summer. Then Mr. Felix sent the carnations. They were 
not in pots, but packed in large boxes. They were at once set out as thickly as they could stand in the east house. You now. see why this border was not as deep as the other. The plants were tall, and by keeping the surface down I gained more room under the glass. Next came the heaths and epacris. As these were to remain in their pots, they were simply placed upon the border, just as they were.

A few days after this I bought at auction sixteen hundred violets, which I planted as closely as possible in their own house, filling it completely.

I also bought of Mr. Clockwell two hundred bouvardias in six-inch pots. As they would grow best in pots they were merely placed in rows on the border of the west house. All my borders were now stocked, except about thirty feet of the east house. This space I filled with fifty fine plants of azalea indica, which I purchased of Mr. McTernan.

My new plant-house is now finished, stocked, and ready for business. I paid every bill promptly. Here is a list :-

Mrs. Maria Gilman

To Reuben Sawplane, Dr.

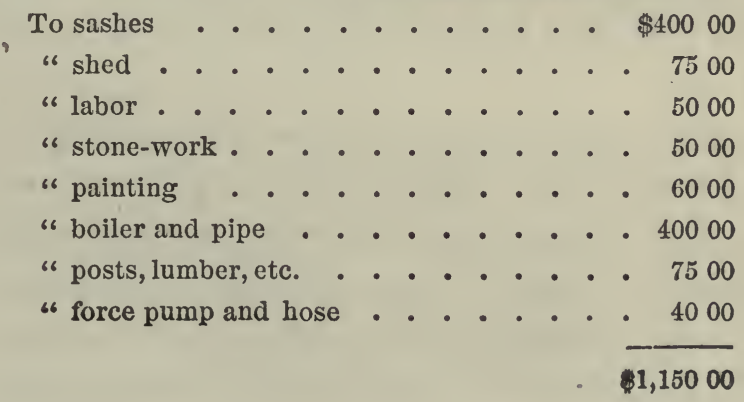


My plants cost as follows :-

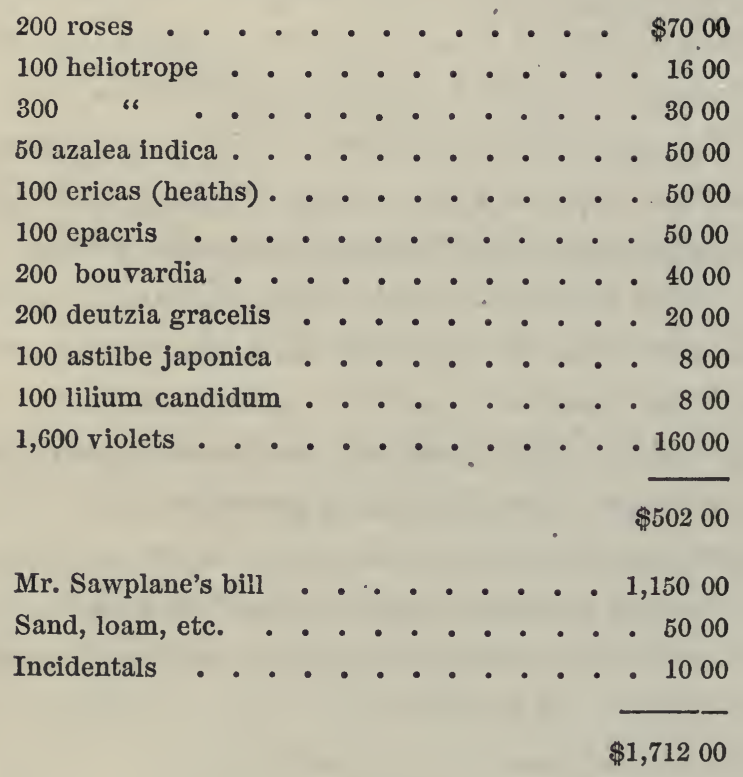

This, then, was the entire cost the day I set up as a regular florist. My bills were all settled on the fifteenth of October, and three days after I cut the first flowers from my new plant-house.

The first week I passed in fear and trembling, not knowing exactly how to manage the watering and ventilation. After a little practice, however, I learned my lesson for once and all. This is the way in which I acquired the requisite skill. I hung up in each house a small thermometer; Mr. Felix then made three cards to be fastened up near 
each glass. For the west house, where the roses and heliotrope were growing, the card read : -

$$
\text { "Sunshine, } 75^{\circ}-\text { cloudy, } 65^{\circ} \text { - night, } 60^{\circ} "
$$

This was intended to indicate the proper temperature under these three conditions. When the day was clear, with abundant sunshine, the thermometer must not rise above $75^{\circ}$. If the heat of the sun sent it above that, enough ventilators must be opened to allow the surplus heat to escape, and so keep the inside temperature within one or two degrees of $75^{\circ}$. If the day was cloudy, the ventilators must be kept shut to preserve the temperature at $65^{\circ}$. If this was not enough, a fire must be started under the boiler, and the temperature forced up to that point and held there. At night sufficient fire must be provided to secure a temperature of at least $60^{\circ}$ till morning.

In the east house the card ran :-

"Sunshine, $70^{\circ}-$ cloudy, $60^{\circ}$ - night, 55०."

The violet house required to be kept on still another scale. This was its card :-

$$
\text { "Sunshine, } 60^{\circ} \text { - cloudy, } 50^{\circ} \text { - night, } 45^{\circ} . "
$$

By the aid of these cards the whole subject of ventilation was reduced to a very simple affair. You will observe that in the night I was obliged to maintain three different temperatures with one fire. This was easily accomplished by means of the "cut-offs." I used the cards for about three months, when I found I could tell by the feeling of the air 
on my face just what the temperature was, and govern myself accordingly, without looking at the mercury any longer.

How to manage the watering, I learned with equal facility, by observing the following rules:-

Never water a plant till it requires it.

Always water thoroughly. Fill the pots brimfull.

The borders need water whenever the surface becomes dry.

The pot plants are to be watered whenever the surface soil becomes dry or the pot becomes light-colored. The water must be enriched with guano, or some other fertilizer, twice a week, and applied with a watering-pot to the heliotrope, roses, and bouvardia. Once a week all the plants must be showered when the sun is. shining brightly.

Time to water, - the morning.

Among other things, I took my tuberoses into the planthouse. As they were quite tall, I was obliged to stand them on the walk. They came into flower soon after coming into the house, and, although they did not bear half a crop, yet I cut an average of fifty cents' worth from each bulb.

The deutzia, astilbe, and liliums I bought in the city, and, when they arrived, stored them in the house cellar.

The deutzia is a hardy shrub, and the astilbe is a herbaceous plant. They came packed in damp moss, and I placed them on the cellar floor and covered the roots with soil to prevent their drying. The lilium candidum is a hardy bulb, and came in a paper box, quite dry. I potted 
them, together with those from my garden, putting two in a seven-inch pot, and set them in the yard that they might be slightly frozen. After staying out one frosty night, they were removed to the cellar. The fuchsias were placed with the deutzias and the remainder of the garden plants were thrown away as valueless.

The month of October had slipped away by the time that all this was accomplished, and November and cold weather were upon us. Let me give you the business operations for the month. As I have said already, my flowers began to bloom almost as soon as I received them. The violets came first, and ere long each carnation gave me a flower or two each day. The statement below shows that I lost money the first month; but this I expected. I drew for the deficit upon my capital, so that on the first of November my stock had cost me eighteen hundred and ten dollars : -

\section{Paid.}

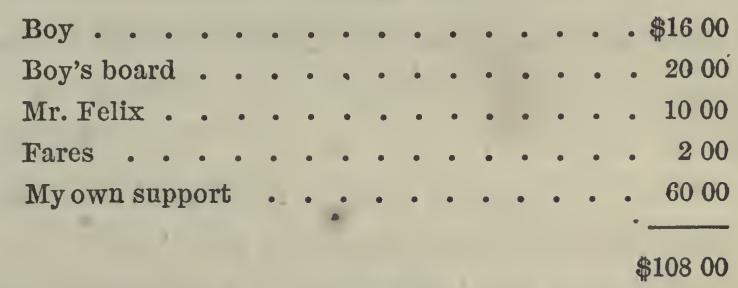

Received.

For flowers . . . . . . . 1000

Balance . . . . . . . . . 9800 
I started the first fire in my boiler on the evening of November second, and from this date kept it up every night till the first of May. The month of November passed away almost without incident. I gave up going to the city, but sent Johnny instead. He carried the flowers in a small wooden box covered with green paper, with a leather strap for a handle. When it became very cold, I used to place a bottle of hot water in the box to prevent the flowers from freezing on the road. As the greater part of my plants were planted in the borders, they required but little attention. To show how I passed my time, I will give you the routine of one day's labor. The first thing to be done was to cut the flowers before the sun was high. Then came breakfast. That over, the bill of the flowers was made out, and Johnny despatched. After clearing up affairs in the house, I went out to the plant-house again, at about half-past nine. If the day was cloudy, and the houses not up to the required temperature, I freshened the fire. If the sun shone, this would be unnecessary, as the heat of the sun alone was sufficient to warm the buildings without artificial aid. Then came the watering, if it was needed. That done, or found superfluous, I spent my time in keeping things clean and in order, for really this was all I had to do. At noon Johnny returned from school, where he had been since his flying visit to the city. He brought me the empty box, and the flower bill duly endorsed by Thomas Dacy. Mary returned at the same time, and at half-past twelve we had din- 
ner. After dinner, I returned to my work. About three o'clock I closed the ventilators, if they had been opened, and at four had the fires built for the night. At sundown I returned to my own house, the labor for the day being nearly over. After supper, I sent the boy out to put on more coal, and, at ten o'clock, I went out with him to be sure that enough coal was on and everything made right for the night. After that, - bed. Now, this was not a hard day's work. In fact, I was surprised to find how easy it became after a little while. It is true, I always had enough both for the boy and myself to do; but it was all very light work, and not tiresome. I found the atmosphere of the plant-house was beneficial to my health. Working all day in a genial warmth and bathed in the full sunlight improved my appetite, and I actually gained two pounds during the first month. When my husband was alive, and, beyond my house-work, I had little or nothing to do, I was not in the best of health, and easily tired. Now, I felt strong, and could work all day, without being half as much fatigued at night.

My flowers continued to thrive, and yielded steadily increasing returns. Here is the statement for November :-

Paid.

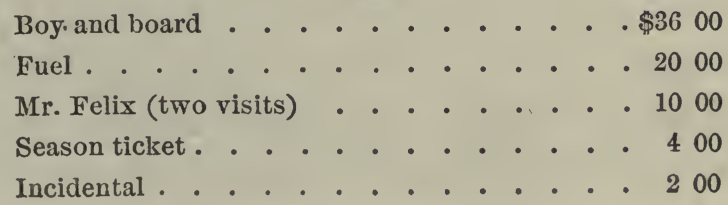


Family expenses
Balance . . . . . . . . . . . . . . . . . $\frac{1}{6000}$

For flowers . . . . . . . . $\$ 15000$

To explain this great improvement in my income, I give below one of the daily bills Johnny carried to the city. At times the bill was larger than this. The amount varied with the weather. On cloudy and stormy days the flowers would not come out so freely as on pleasant days. In fact I soon found the amount of sunshine was a matter of dollars and cents to me. If I had less sunlight, I had less flowers, and, consequently, less money. I assure you, I looked out for the sun with all the eagerness of a photographer. Here is a day's return :-

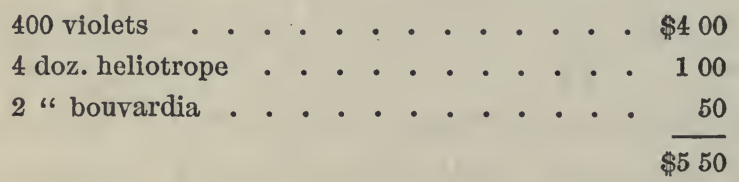

December passed without any mishap. The flowers bloomed more and more freely day by day. The fall heaths came into flower, and the tuberoses ceased and were thrown away. The people in the village began to look upon my operations with more favor, and even condescended to visit my establishment. When they commenced calling I was . very attentive to them, but as this took so much time I leit them to inspect things under their own guidance. As the days grew shorter I was obliged to light the fires much 
earlier, and even keep them up during the day. This added to the expense, but not materially. On Christmas day some of my neighbors wished to purchase some of my flowers; but I declined to sell, as the city store had a prior claim. That day I sent in twenty dollars' worth, - a larger amount than $I$ had ever expected to receive in one day. This the December statement :-

Paid.

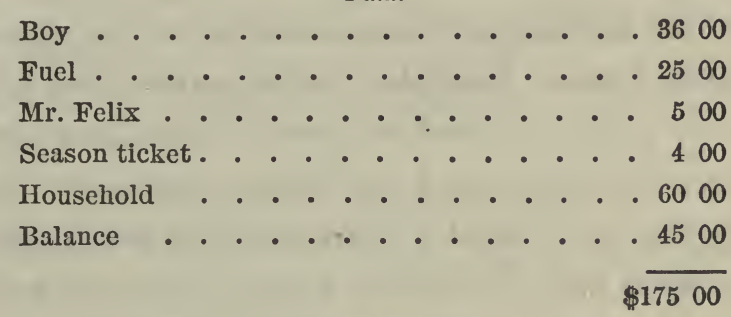

Received.

For flowers . . . . . . \$175 00

The interest on the mortgage became due on the sixteenth of this month, but I readily obtained credit till my money came in, and then I paid it, together with the taxes, and had just two dollars left to begin the new. year.

' Soon after the first of January we had a severe snowstorm that covered the ground two feet deep. This proved greatly to my advantage, for the snow acted as a blanket and kept the ground warm. My plant-house being half sunk in the soil received the full benefit of this, and my coal bill was actually reduced.

On the last evening of the month we had a violent rain- 
storm. After supper I sat down to add up the amounts upon my flower cards, and ascertained that my sales at the store had reached one hundred and eighty dollars, while I had sold to persons who came to the door ten dollars' worth; making in all one hundred and ninety dollars for the month.

The storm was so severe at ten o'clock that I called Richard and gave him the key with directions to put more coal on the fire, and see that the damper in the chimney was nearly closed. Delegating to my servant such work, instead of going out myself and seeing it done, was a fatal mistake, that nearly caused my failure in business. When the boy returned I asked him if everything was all right, and he said it was. During the night it cleared off and in the morning a cold north-west wind was blowing. As soon as I entered the plant-house it struck me as being very cold. Going to the thermometer in the west house I found the mercury down to $30^{\circ}$. I toucheu ine leaves of a heliotrope. It was stiff, - frozen. Going to the east house, I consulted the glass again, $-28^{\circ}$. Opening the violet house I discovered every plant completely frostbitten-and the glass at $26^{\circ}$. Returning to the shed, I opened the fire door in the boiler. The fire was quite out, and the pipes cold. Looking at the chimney I found tne damper wide open. The boy had not touched it, and, the wind rising, had started the full draft, and the fire had burned out. Utterly mortified, discomfited, and heart- 
broken, I returned to the house, threw myself on the sofa, and burst into a flood of tears. And this is the end of all my labor, and all my waiting and watching. In one night my plants destroyed and my business prostrated. So much for the carelessness of my servant, and my own folly in trusting to another what I should have attended to myself. Surely, I have learned a lesson, - but at what a cost.

Suddenly the door-bell rang, and in a moment Mr. Felix stood before me.

"Why, Mrs. Gilman, what is the matter? Are you sick?"

"No - yes - yes, I am sick, - It's enough to make any one sick. I've failed, - I know I have."

"Failed! How so? Have you lost your pay through the failure of the store?"

"No, no; it is not that. The fire went out, and - and —oh, I'm sure I have failed in everything."

"The fire went out! when?"

"Last night, and every plant is frozen stiff."

Then I buried my face in my hands, and sobbed as if my heart would break. Presently I felt a light touch on my shoulder.

"Mrs. Gilman, you must rouse yourself. You must not give up in this way. There is no time to lose. Everything depends upon prompt action."

"No, I cannot, Mr. Felix. I have worked too long and too hard already, and I'll do no more. It is of no further use." 
"You are not yourself, Mrs. Gilman. Come, make one more effort. Perhaps we can save a portion of your property."

"No, I cannot."

"But you must. What are the children to do if you give up in despair?"

"The children! What of them?"

"I say you must come out with me and see if we cannot repair damages."

"I am ready. I will be calm. What must I do first?"

"In the first place send Johnny and Mary for every blanket, sheet, cloth, or carpet they can find, and then let them cover the glass with them to shut out the sun. Bid them hasten as the sun will soon be high. Call your boy also, and have him build a fire as quickly as possible, and, as for yourself, come with me to the plant-house."

On reaching the building he went to the pump, and, unrolling the hose, placed the brass nozzle in my trembling hands, saying:-

"Now let me pump, and do you go carefully over every plant and drench it with water."

Dragging the hose after me, I entered the west house, and at once the pump began to work. We worked in si. lence. There was no sound save the steady clank of the pump, the rush of the water, and the loud beating of my heart. 
While we were thus engaged the place was gradually darkened by the cloths placed on the glass outside by the children. By the time I had watered that house, every ray of sunlight was shut out. Then, with Mr. Felix's help, the hose was removed to the east house, and I began again.

Suddenly the door opened, and my brother Joseph entered.

"What's the matter, Maria?"

"My fire went out, and the plants are frozen."

"Frozen, are they? Just what I expected. I told you, you would fail up, some day."

"Did you?"

"Yes, I did, and now I hope you will listen to your friends and reason."

"Move, Joseph, please move; I must water my plants. Come another time, please."

"No, I'll not move."

"But you must!"

"No, I will not. You shall hear me now. I say you must give up this — "

"Joseph, you must move on, or I shall wet you."

"I say you must sell out and give this thing up."

"Move on, please."

But he would not, and, calling to Mr. Felix to give more force to the stream, I made a slight movement of the now powerful stream. My brother's coat-sleeve glistened with the spray. 
"Now, Joseph, you must come another time. I am busy now. I cannot talk with you, - move, please. You will be drenched if you stand there."

Finding me resolute, and observing my now really formidable weapon, he beat a sullen retreat. As he passed through the shed Mr. Felix said something to him. What it was I never knew, but I soon saw Joseph slinking out of our gate.

Finishing this house, I moved on to the violets. But they looked so badly, that I called Mr. Felix from the pump.

"What can we do with them?"

"Do with them? - nothing, they are entirely spoiled. You had best shut up the house for the next two months. You can do nothing with it. It is a great pity! There must be upward of two thousand flowers on the plants."

Just. then Johnny, who was standing on the snow outside, called through the glass :-

"See, mother, there aint any more sheets. We have covered the heliotrope and the violets. But we can't cover any more."

"Take them off the violets and shade this house," said Mr. Felix.

Accordingly the children made the change.

"Now, Mrs. Gilman, let us see how great the damage is, and what we can do to repair it. So we went over the whole place and that night I had carried out his direction. 
We worked hard all day, and at evening the place presented this appearance: All the heliotrope had been pulled up and thrown away. The roses had been cut down to bare stems. The azaleas were not materially injured. All the ericas, azaleas and epacris were brought in and placed upon the borders in the west house. The flowers upon them were injured, though the plants were not hurt much. They would do for next winter's use. The bouvardia were in full bloom, but the flowers were quite spoiled. The plants were cut down, and the roots that remained in the pots were stored in the cellar. By this change one house was cleared, and the remaining plants gathered together in the other house. The empty house was shut up and the heat cut off to save fuel. The violet house was also closed. As I went in to cut off the heat, I noticed that all the plants were quite black and dead. Then I understood why Mr. Felix was so anxious to exclude the bright rays of the sun, and why I was directed to water the plants we hoped to save. The water took the frost out slowly, and the shade prevented a too sudden change from cold to heat.

The next day the news was all over the village, and the whole place rang with one loud cry, "I told you so! I told you so!"

As I had no flowers to send to the city by my son, his absence was at once noted. In a day or two Mr. McTernan called.

"It's froze, are ye? I'm sorry for ye. I declare it's 
too bad. But, I tell ye what ye can do. Ye can fill up your empty house with bedding-stuff, and in the spring ye'll be all right again."

"But what is bedding-stuff, Mr. McTernan?"

"Why, verbenas and such."

"But I know nothing of their culture."

"Oh, they is easy enough. Ye rig up a sand bed, and I'll send ye the cuttings this day."

"Thank you, Mr. McTernan, but I cannot pay for them. I have but little money left."

"Never ye mind the pay. If ye make anything ye may give me a cent for each. If ye don't it's all the same."

Determined to do something to help myself out of my troubles, I had further conversation on the subject, and agreed that he should send me a thousand cuttings the next day.

Mr. Felix called in the afternoon, and to him I mentioned the bedding-plant idea.

"Just the thing," said he, "and tomatoes. You can fill your east house with bedding-plants, and the violet house with. tomato plants. They will sell readily in May and June. If you try it I am sure you can make up your losses, and come out on the first of July right side up. And there are your deutzias and other plants. Bring them from your cellar and place them in the empty house, and force them. Besides I have here some wonderful seeds, 
warranted to pull any one out of any pickle, though they sometimes get in themselves." And, laughing to himself, he laid in my hand a package of seeds.

"What shall I do with them?"

"Get two hundred three-inch pots, and fill them with fine soil from your violet house. Plant three of these seeds in each pot. When the plants come up, remove all but one from each pot. Keep them growing rapidly, shifting them from pot to pot as they advance, and in about sixty days you will see some flowers which I imagine will be new to you."

"But what are they?"

"Wait and you will see;" and, with a pleasant smile, he bade me good-night, and went his way.

Miss Sampson also called. She told me not to be discouraged by my disaster. It was not such an uncommon occurrence. The best of florists' houses sometimes freeze, and yet the owners always manage to get out of it somehow, and there was no doubt that I should likewise.

, Now I cannot give you all the details of my doings for the next three months. It would take more time than I can command. I can only say that I went to work bravely, and by the first of May had raised five thousand beddingplants and five thousand tomato plants. To bring this about and to make up my deficit for the months of February and March, I used up all I had made and all my capital besides. In April my plants had so far recovered 
that the sales of the flowers met the expense of their culture. In the middle of April I put this advertisement in our weekly "Journal" : -

\section{"BEDDING AND TOMATO PLANTS FOR SALE. \\ M. GILMAN, FLORIST, MAIN STREET."}

I also put up a sign on my gate:-

"BEDDING AND TOMATO PLANTS FOR SALE."

About the tenth of May, the neighbors, and others living in the town, began to call for bedding-plants, and my time was fully taken up in retailing them to the crowd of people who thronged my place every pleasant day.

Among them came Mrs. Jacques. She bought a few plants, and wanted credit for them. I gave it to her unwillingly, as the plant and flower trade is strictly a cash business. Its very nature makes it so.

A few days after she called, there was a red flag displayed at her husband's door, and I overheard this conversation between two men on our sidewalk. I was in the plant-house at the time, but as the ventilators were open I could hear every word.

"Old Jacques has gone up, they say."

"Yes, served him right. He was too lazy to work, and so failed. By the way, Dick, if you do want to see a 
worker, you just step into the greenhouse yonder and see the woman-florist."

While this.was going on, a wagon drove slowly past the gate. In it sat a farmer with his little girl. Seeing my sign, he pulled up his horse, got out, and came in.

"Is Mr. Gilman in?"

"There is no Mr. Gilman."

"Who is M. Gilman? I want some tomatoes any way."

"I am Mrs. Gilman, and if you will come this way I will show you the plants."

On entering the violet house, he seemed greatly pleased with the appearance of things. Walking up and down the path, he looked at the plants, and ran his hand over the tops as if to feel how stout and stocky they were.

"Wall now, them be purty plants. Did you raise them yourself?"

"Yes, sir."

"Wall, now, that beats all I ever heard. And you are a woman-gardener, are you?"

"I am trying to be."

"Come now, they is good ones, aint they? Lordy! who'd a thought it? I must tell my old woman. A woman-gardener! How much do you ask for them, ma'am ?"

"Fifty cents a dozen."

"Oh, don't mind the dozens. It's not by the dozen or hundred I wants them. What do you charge for a thousand?" 
"Thirty dollars."

"Take twenty-eight."

"No, sir."

"Wall, it's mor'n I'm paying, but they is extra, they is. I'll take three thousand. The boys will come over for them in a day or so. You may give them five hundred at a time. I can't come myself again, and, seeing you are a woman, I'll pay you now while I have the money." Taking out an old leather purse, he placed in my hand ninety dollars, and then drove away.

When he had gone, I unrolled the money and looked at it. Suddenly the moisture gathered in my eyes. Leaning my head upon the edge of the border, I gave way to a flood of tears. Not tears of sorrow, this time, but tears of joy and thankfulness. Surely God deserts not the widow and the fatherless.

From that day the Lord prospered me. I sold all my bedding-plants without any difficulty. The aggregate amount I received for them was four hundred and twentysix dollars and fifty cents. The tomato plants yielded one hundred and twenty dollars more. With this money I paid Mr. McTernan, and, after settling every bill had enough left to take up one half my mortgage.

On the evening of the Fourth of July, just a year from the day I began, I invited Miss Sampson, Mr. McTernan, Mr. Felix, his wife, whom I found to be a charming lady, and their two little girls, to a grand strawberry supper. 
While we were at tea, we heard a great pounding in the yard, and, sallying forth, discovered a man nailing up a new sign on top of the plant-house.

"I thought I would celebrate the day by sticking up your new shingle."

Waving aloft his hammer, he exhibited the result of his labor : -

\section{"MARIA" G ILMAN,}

FLORIST."

"Long may she wave!" shouted the sign-painter.

Then the gentlemen all cheered, while the ladies waved their handkerchiefs, and we all had a merry time.

At ten o'clock my friends departed. I shook them each by the hand, and, with tears in my eyes, thanked them for all their kindness.

But stop, - let me tell you about the seeds Mr. Felix gave me. I planted them as he directed. They soon came up, and exhibited a tendency to run, proving they were vines. I shifted them from pot to pot till they were a yard long, and in a seven-inch pot. By this time they were covered with small yellow flowers. I asked Mr. Felix what I should do with the flowers. "Let them alone and see what becomes of them." After the bedding and tomato plants were gone, and the other plants, except the roses, removed out of doors, the vines were planted out three feet apart in the borders, filling both houses. They soon took root in 
the rich soil and grew rapidly. In June they bore fruit, and in immense quantities. We were obliged to spend an hour every evening in gathering the fruit and packing it in boxes. Every morning Sharpedge \& Co. sent a light wagon and took it away. I sent them the following bill in August. If you read it you will see what it was:-

Messrs. Sharpedge \& Co.

To Maria Gruman, Dr.

For 3,600 cucumbers at 3 cents, . . . . $\$ 10800$

Received payment,

Maria Gilman.

Let me now review my operations for the past six months. Here are my monthly sales :-

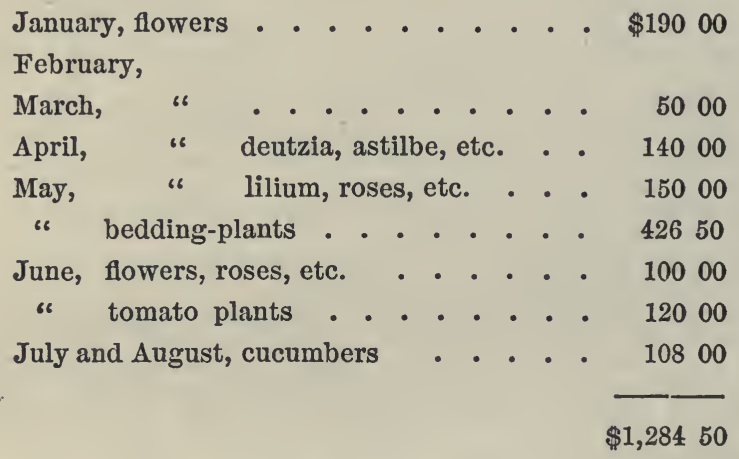

My expenses to July (including the support of my family) amounted to eight hundred and fifteen dollars. 
I was obliged to give up my flower garden after this, as the buildings occupied nearly all my land, and what little remained was filled with my flowering stock for the winter. However, this was a small affair. I could well dispense with my garden flowers now. In addition to the bedding-plants, I raised a quantity of violets and carnations for my next winter's use, so that I was not obliged to spend so much in the fall for new stock. In fact, I spent but very little. My last winter's stock so far recovered as to be used again the next season.

And now my story is told. I have led you step by step through the first year of my business life. You have seen my failures and my successes. As I said at the outset, I am sole proprietor of "My Ten-Rod Farm," free from debt, and in receipt of an income of two thousand dollars a year. I did not reach this point the first nor the second year, but my income has gradually increased till it reached that amount.

The village people speak of me with praise and respect. My brother and sister say but little. They let me alone, and treat me respectfully. To Mr. Felix and Mr. McTernan ' I owe a debt of gratitude I can never repay. However, you must not imagine I met with equal kindness from all the trade. I suppose I met the same amount of kindness, and the same amount of opposition and hindrance, that I should have met if I had started a cheese factory, or 
built a stocking mill. Yet in my profession I am respected and treated with consideration by all. As I said at the outset, I have made a place for myself in the world. I have told you this, my story, with a purpose. Many have called upon me for the facts, that they might aid some deserving person left as I was, just removed from want's door.

The consumption of flowers is enormous. The number of greenhouses has more than trebled since I built mine; yet to-day the price is higher. I cannot think that this will continue. The price will eventually come down, which will be an advantage, alike to the grower, seller, and consumer. In such a business as this, it is not the high price, but the great quantity demanded, that is advantageous to the producer.

Flowers are the delight of every one. They are appropriate and acceptable at all times, and in all places. No place is too common or too sacred for them. They peer over the tops of the banking-house desk, and their fragrance adds a new charm to the solemn roll of the church organ.

Hundreds of women living near our larger cities are eager and willing to do something to add to their slender income. If this account of my experience aids them in any way, my object is accomplished, - I am satisfied. Mrs. Warren's charming "Home Manuals," for house management, "Our Farm of Four Acres," "The Garden 
that paid the Rent," "Ten Acres Enough," "How to Farm Profitably," are eagerly sought after. May I not have the same good fortune awarded to

$$
\begin{gathered}
\text { Mr Ten-Rod FarM; } \\
\text { oR, }
\end{gathered}
$$

\section{How I beCAME a Florist.}





\section{STRAWBERRIES, GRAPES.}

THE STRAWBERRY GARDEN.

HOW IT WAS PLANTED,

WHAT IT COST,

WHAT CAME OF IT, FINANCIALLY AND SENTIMENTALLY.

JQHN AND KATE WELLSON'S SUCCESSPUL EXPERIMENT. 



\section{THE STRAWBERRY GARDEN :}

\section{A VERY PRACTICAL STORY.}

\section{CHAPTER I.}

INTRODUCES THF PEOPLE AND THEIR WOES.

Mr. John Wellson, wife, and three children, - Mary, aged seventeen, Kate, fourteen, and John Junior, or Johnny, twelve, or thereabouts. These for people. Numerous wants, and the lack of funds to supply them, for an argument. Details directly.

Time, evening, June 19, 186-. Scene, the Wellson parlor. The whole family met in solemn council. Mr. Wellsan, head-master in a public school in the neighboring city, occupies the great arm-chair, and for the moment is lost in gloomy meditations.

Mrs. Wellson, familiarly known as "mother," - a bright and cheery body, with a kind word and ready smile for all, - sits in her low rocking-chair quietly mending a stocking, and thinking, thinking, - and thinking to no purpose. It is a trying subject they have under consideration, and even her sharp wits cannot penetrate it.

Mary, the eldest daughter, loveliness, common sense, and 
affection combined, is vainly trying to read a book upside down, and with her thoughts decidedly elsewhere. The family troubles are dull and hard, but they touch her upon a tender spot. Prosaic as they are to the others, to her they are keen enough, and in a far different way. Every joy of her young life hangs upon the miserable question before the household. Not in reality; yet she thinks so, and that to her is quite as bad.

Kate, her sister, a wholesome, luncheon-loving girl, with abounding animal spirits, and possessed of ready wit, a sharp appetite for fun, and good nature enough for two men and a boy, is seated in boyish fashion upon the floor. With earnest eyes she gazes at the carpet in silence.

Her brother, a boy of the hearty, wide-awake order, is seated on a low stool beside her, and for a wonder is quiet. $\mathrm{He}$ is very sober. Upon him the family sorrows weigh heavily. The world is a dull place and life is very sad. It is his ambition to wear " a coat with tails, like the other fellows," and the parental funds don't admit of it.

Attention! Kate speaks: "Well, I think the worst thing that ever happened to this family was the unhappy circumstance connected with my birth."

"Hush, Kate!" said her mother.

"No, mother, let me free my mind. I shall feel better. I say it's a pity I wasn't a boy. Then" - and she sighed fervently - "then I could go to work and earn something, and help father out of this scrape." 
"Fie! Kate," exclaimed Mary. "One would think you were one now."

There would have been a sharp retort had not Mr. Wellson interrupted them by dragging up once more their little private skeleton and rattling its bones before their sad eyes. Said he:-

"The case is just this: Here we are, hiving in this expensive house and keeping up a certain position in society, and our funds at such a comparatively low stage that disagreeable rocks and shoals are visible at every tide."

"In other words," added John Junior, gravely, "the stamps don't hold out."

"That's it, my boy. We are living beyond our means, and something must be done about it very soon." •

"Can't we sell this house, my dear? A smaller one would be less trouble to keep in order."

At these words Mary's heart fell down two degrees and a tenth, and her mental atmosphere was depressed. To move away just now would be disastrous.

"We might sell," replied Mr. Wellson, "at a heavy loss."

"Yes," said. Kate, "and go into some box of a house, and live like six mice in one hole, and lose our garden, and the grapes, and all the nice things, and have those wretched Scrabbins girls say things, and cut us all dead. Oh! isn't it dreadful? I declare it's awful; really and truly. I hope we shall move a hundred thousand miles from here, 
and where there isn't anybody who knows us, and where we don't know anybody. Oh, if I were only a boy! I'd fix things."

"Would you though? Come, tell us, Kate, what'd you do?"

"Work ! - work like a house a-fire."

A hearty laugh greeted this burst, and things actually looked brighter. To such a stirring young body everything seemed possible.

"Now, father, let's not beat about the bush. Tell us just how things stand. Perhaps it isn't so awful bad, after all."

"No, Kate, it is not such a terrible affair. Only a little matter of one hundred dollars."

"Oh! is that all?"

"Yes; but every year we are that amount short. For the past few years a small sum in the savings-bank has served to eke out the deficiency. This belonged to your mother, and she insisted upon its use that you children might continue in this pleasant home a little longer. Now it is all gone."

"O you good, dear, dear mother!" cried Kate, jumping up suddenly and planting her liberal self in her mother's lap, to the demoralizing of work-basket and mending; "you're better than cranberry jam, or frozen pudding, and that's heavenly, you know."

Mr. Wellsen went on: "We shall do well enough till the 
winter's coal is to be bought. Every other bill paid save that, and no money on hand. Now the part of wisdom is plain. Hedge our expenses, and live in a smaller house, or in less style."

At this statement a dreadful silence fell upon the company, only to be broken by the entrance of Helen, their one servant, to announce supper. Gathered "round their simple board they ate their tea and toast in silence and bitterness. At the end of the meal a full dish of ripe strawberries was brought on. At sight of this their spirits revived, and the lively Kate began again with her perpetual talk.

"And the strawberries, too! To think that we shall lose them all! I shall eat a double share till we move away. Don't know when we shall ever have any more. We - are - so - dreadfully - poor."

Spoonfuls of berries and cream served to point this remark.

- The berries are the very things that trouble us, Kate," said her father. "The expense of keeping up our garden is the one straw that breaks our particular camel's back. The plants and the labor expended upon them cost last year more than enough to make us whole. Another place, having either more ground, so that we could sell a part of the produce, or less ground, to save all expense, would help us. As it is, the cost of our grounds is too great for us to maintain our present position in society."

The meditative Johnny, coming out strong on the side 
of financial common'sense: "Bother position in society! Let's keep out of debt, any way. Who cares if we don't live in this house, or on this street?"

Both the girls held up their teaspoons in horror.

"Position is everything. How'd you like to give up your playfellows and come down in the world?"

"Hush, children!" said their mother. "You are getting very worldly. Society is not everything."

"Yes; but it is so hard to come down."

Further discussion followed this, and after a while Helen came in to clear the table, and the subject was dropped. Soon after Mr. Wellson took to his account-books, and with his wife went over for the twentieth time the long columns of figures that represented their dull sorrows. Such petty and harassing work. The ins and the outs were persistently at variance, and their eyes ached over the wretched matter. What discouraging work, and how destructive to all that is best in life! And yet it must be done. Oh, debt! what a horrid, horrid thing it was! How could a man be a saint, or a woman the angel she ought to be, while in debt?

As for the children, Mary tried to read, Kate was silent, and much given to wishing she were rich; and Johnny was lost in a brown study. At nine the evening came to an end, and they sought the best country for them, - the land of sheets and dreams, Mary dull and dispirited, Kate very sober, and her father and mother weary and harassed. As 
for Johnny, a brave idea struggled in his mind, and he was restless and wakeful.

Having safely tucked them in, let us briefly consider their case. A very worldly set of people, the reader remarks. Not a doubt of it; yet, in drawing this picture the writer fancies that he has been true to nature. Thousands of families keep in their best closet just such a miserable little skeleton as this, and gaze upon it in precisely this very human way. Did the really best society depend upon money alone, such views would be despicable. As, happily, it depends, in this country at least, more upon brains and education, the seeking for it is not so very bad.

To aspire to a high position is wise and honorable. The higher one goes, the less are life's temptations and the easier it is to be virtuous. The lower we descend, the greater they become, till actual porerty is reached, where crime has become proverbial. The so-called "criminal classes" are always the desperately poor and uneducated.

The society in which these people sought to maintain themselves was that of the average American of common and high school education, - society such as is found among the doctors and lawyers in a New England village, or the commercial classes in our large towns and cities.

In view of these things, let us look farther into the doings and sayings, struggles and triumphs, of this family in their endeavors to keep up in the world. 


\section{CHAPTER II. \\ THE MIDNIGHT RAID.}

Trat night, soon after the owl train had shrieked through the village, and just as the rural chanticleer had finished his last farinaceous dream and was sleepily tuning his horn, two of the family awoke. Do what they would they could not sleep again.

The restless Johnny, after piling Alps on Alps with the bedclothes, and muttering to himself that "he'd do it, sure as sixty," sat up in bed and looked out of the window at the waning moon.

Just beside him in the next room his fister Kate also sat up, with wide-awake eyes, and wondering if "she heard robbers or anything."

For a while all was silent. Then she heard a queer sound just outside her window. In a little fright she hid her head in the bedclothes. The noise went on. A sound of footsteps on the roof of the piazza by her window.

Resolved to be very brave, she slipped out of bed, scrambled into a wrapper, and grasped her shoe to fling at the burglar. Looking out, she beheld a young lad standing before her window. She was upon the point of indulging 
in a scream, when she saw that it was her brother. Push. ing up the sash gently, she put out her head.

"Why! Joh-".

Johnny motioned her to be quiet. In a whisper: "Don't speak loud, Kate; you'll wake 'em."

"No, I won't. What's up?"

"Nothing, nothing. Only do talk quiet. You'll wake 'em up, and spoil my fun."

At this word a bond of union was established between them at once.

"Fun! Oh! what is it? Is it a serenade for Mary? Tell us. I'm dying to know."

"It's hooking, Kate."

"O Johnny, you are not going to run away to sea to get money to help father?"

"No; but I'm bound to help dad, and I'm going - to — won't you tell ?"

"No, truly and really."

"I'm going to steal some of our strawberries, and sell 'em. It's awful bad, I know; but it was dad made me think of it. He said if we had more land we might farm it, and sell the stuff, same as Farmer Gooding does. Didn't I see the women a-picking berries there yesterday, and I guess if those gals can, I can."

"So you can, and it isn't bad at all. You can take your share, and go without at table. That'll be fair. You can have my share too, if you like." 
"You're a trump, Kate."

"Now be quiet, and don't break your neck in climbing down."

Johnny disappeared and Kate softly closed the sash.

"What a boy! Who would have thought it of him? Not a bad idea though, there's heaps and heaps of berries, and they'd bring some money if we could sell 'em. What time is it? Half-past three, if the moon says true. It will be light soon. I know what I'll do. I'll help the boy, and and let him in at the back door."

A few moments later a dark-robed figure might be seen creeping from the back door of the house, and stealing along the damp walk that extended down the centre of the dewy moon-lighted garden.

An odd little spot, half-hid by tall trees and the neighboring houses. On the north side a row of pear-trees nearly shut off the view from the dwelling-house, and made the garden a quiet and secluded spot. A board fence, covered with grape-vines, extended for two hundred feet along the west side, and on the south a low stone wall divided the grounds from the open fields beyond. On the east a large wooden house pushed its windowless back close up to the boundary line. More board fence finished the outline.

As for the general aspect of the place, and the things growing in it, nothing could be said, as all was dark and shadowy. It was only by knowing the locality well that 
the muffled figure was able to find its way. Down by the stone wall it encountered a black figure crouching among the wet vines. As the walking figure approached, the other started up and stood erect in the chilly moonlight.

"Why, Kate, is it you? How you frightened me!"

"Yes, I've come to help you. Give me a box."

"Haven't got but one."

"That won't do. What could you do with one box of berries? They would laugh at you at the market. I'll get something."

Kate flitted silently away in the gloom, and soon returned with an empty basket.

"You don't think we can fill that?"

"Why not? We have two good hours before anybody will be up. We can do it in an hour, if we work like fun."

And they did, - in silence and with speed. Busy with their work they did not notice the coming dawn, and almost before they knew it the tall chimneys of the next house stood black against the gray sky. The light crept upward and the moon hung low in the west.

When the basket was nearly full they paused to take breath.

"They don't look very nice. Do they ?"

"No, Johnny. They are very wet, and - oh! we haven't hulled them."

"Then we ought to do it." 
"We can't. There's no time. The sun's most up and we shall be found out."

"I don't think they will buy them in that state."

"Then you must offer them for less. Whatever you do, sell them."

"That I will. I'll start now. The shops will be open soon."

"All right. I'll sit up for you. I'm all dressed and haven't anything more to do till breakfast-time. My! how hungry I am! I wish breakfast was ready now."

"I don't. 'We'd be found out, sure. Good-by, I'm going."

And, with the basket on his arm, he scrambled over the stone wall and disappeared.

Never did maiden watch in lonely tower for her lover from over the sea with more anxiety than did Kate, with her pretty nose flattened against the cold window-pane, for her runaway brother. At last, just as the sun appeared over the trees, he came quickly up the walk under the pear trees. Opening the window, she telegraphed to him by signs that she would come down and let him in.

A moment after she stood beside him in the yard. The basket was gone.

"How splendid! you sold 'em?"

"I did that."

"Come in. Oh! I'm so - " 
The back door opened, and, to their infinite astonishment, their mother stood before them.

\section{"Why, Kate! Out so early?"}

"Here's mother," said Kate to her brother. "The cat'll have to jump, surely."

"She will tell."

"We will ask her not to."

"You won't tell father, will you, mother?"

"Tell him of this?"

"No, but you see, I was out in the night," said Johnny, honestly.

"Out in the night! That is a very serious thing. I must acquaint your father of it at once."

"O mother, mother!" exclaimed both. "Don't. We did not mean to do wrong, and we are both to blame.""

Mrs. Wellson looked from one to the other. Plainly they had spoken the truth. After a pause, she said,. "This is very serious. Go to the dining-room, Johnny, and wait till I come. And you, Kate, how happens it your dress is so wet round the bottom?"

"O mother, perhaps we were dreadful wicked, but we will tell you all."

Like good children they met their mother in the diningroum, and told her all. When the story was finished Mrs. Wellson sat down perplexed.

Such proceedings were certainly not right, and yet no. 
serious wrong-doing was intended. After some reflection she made up her mind what to do.

"What you have done, children, was neither proper nor right. It must not happen again. If you are to sell the berries it must be in broad daylight, and with your father's consent."

"May we sell 'em?" said Johnny. "Hi! won't it be fun? I sold 'em this morning easy as sixty. See, here's the money."

So saying, he took from his pocket some dirty bits of scrip and spread them on the table.

Kate and her mother stooped to examine the four greasy bits of paper, - twenty-five cents each.

"You don't say, Johnny," exclaimed Kate. "All that for your berries? You will get a heap of money if you go on at that rate. It's pretty dirty money they gave you - "

"Never mind," broke in Johnny. "It's just as good to pay your debts with."

"They certainly did pay you well," said Mrs. Wellson. "You must be good at a trade."

"Oh! I fixed 'em," said the proud Johnny. "It takes me to sell things."

"Tell us about it," said Kate.

"Well, you see, the first store I came to was just being opened, and in I marched. 'Want any strawberries?' says I.

"'Let's see 'em,' says the man. 
"I showed him the basket, and then I remembered that the hulls were on. They looked pretty bad, and I thought they were not worth much. The man looked at 'em, and says, 'They aren't hulled.' - 'No,' says I, ' they are not.' 'Don't want 'em,' says he. 'All right,' says I, and got ready to go, when $I$ saw a gentleman looking at 'em pretty hard. Says he, 'They are much better for having the hülls on. They keep longer. The best way would be never to sell strawberries with the hulls removed.' - 'It isn't the fashion,' said the store-man, 'and they won't sell till they are hulled.' - 'Perhaps not,' said the gentleman; ' but they are much better so. Besides, the boy has wisely put them in a shallow basket instead of those tight wooden boxes sometimes used. They are probably free from all woody flavor.' - 'Well,' said the store-fellow, getting angry, 'I don't want 'em any way.'

"I went out, and soon came to another store. 'No, they did not want 'em. 'Theý never bought berries in bulk.' Then I was mad to think that I did not know enough to hull and pack them before I started. I thought I'd stop somewhere and hull them, but I could not find a good place. Then I came to another store. 'No, they did not want berries.'

"By this time the basket got pretty heavy, and I guessed I'd throw it away and call it profit and loss, - mostly loss." "Oh! you didn't didn't you, Johnny?" exclaimed Kate. 
"No, my dear, I didn't. I kept it and tried another store. Here I changed my tune. You see I was provoked, and didn't care what I said.

"Marching in very brave, I said, 'Want any fine fresh strawberries? Got the hulls on, to keep 'em fresh. Picked this day. In prime order, 'cause the hulls are on. Makes 'em keep better. In bulk, to keep them sweet.'

"There were two men in the store, and they both came to look at my berries.

"'How much?' says one, poking his fingers into the berries.

"'Twenty-five cents,' says I. 'Thirty cents, if you spoil 'em by poking them over in that way.'

"The man stared, and the other fellow laughed.

" 'Do you want 'em?' says I.

"' 'No,' says he.

" 'Prime berries,' says I. 'Warranted to keep, 'cause the hulls are on.' Then the other fellow looked into a little book he held in his hand and said, 'Guess we'll have to take 'em. It's a tremendous price; but they are very early. Here's your money;' and he took the basket and gave me this.

" 'Yes,' says I, 'they are early. Half-past four in the morning. Very early.' Then I started for home, and you know the rest."

"But, Johnny," cried Kate, lifting her hands, "where is the basket? You did not sell that too?"

"Oh!" exclaimed Johnny. "I never thought of it." 


\section{CHAPTER III.}

PRIDE VERSUS MONEY.

That afternoon, about four o'clock, Mary Wellson could be seen dreamily walking up and down the gravelled walk at the lower end of the garden. With downcast eyes she paced back and forth, apparently lost in thought, yet really with sharp eyes and ears, ready to catch the sight and sound of any passers on the little path which wound over the grass in the pasture just beyond the wall. Every few moments a quick glance was cast towards the field, or to the house at the upper end of the garden. From one direction she hoped for some one's coming ; from the other she feared anybody's approach.

"Why don't he come?"

An old, old question asked once more by fresh lips.

"Why don't he come? He knows I wait for him."

More steps alone, and further efforts to quell the rebellion in her young heart. A rebellion and protest against the family fates. Why did these wretched money matters come in just now to ruin all her hopes?

The pretty fingers 'twisted themselves together tightly over her breast, and the bright eyes were sparkling with unaccustomed tear's. 
"Will he never come? Only one paltry hundred dollars, - and to lose all for so little. If he would only come, that I might see him before we move away.".

The sad eyes gazed far away towards the distant hills and the declining sun.

"Will he never - "

A sudden arrival: Kate, the luncheon-loving, with a piece of cake in one hand, and a tin pail in the other.

Mary turned away to hide her face.

"Hallo, Polly! What you doing here?"

"Nothing. How came you to be so rude, Kate? You are as bad as any boy."

Kate's opinion of boys had gone up three degrees and a tenth since morning, and she was proud of the race. Between her bites at the cake, the conversation went on :"All right" — cake. -_ "Glad of it" — cake._- Boys are" - cake - "jolly. Like 'em" — cake. — "Say, sister, won't you lend" - cake - " us a hand" - cake "at picking strawberries?. Johnny and I are going to pick a lot, and" — cake — "won't you tell?" — cake. — "We are going to sell 'em" - much cake.

"Sell them, Kate! What are you thinking of?"

"Of nothing, except the money they will bring."

"Sell them for money! Are you crazy?"

"No, think not. Come, lend us a hand."

Much cake; and then she stooped down, and, tucking 
away her skirts, gravely began tc eat cake and pick berries at the same time.

- Mary stood beside her irresolute, and with keen eyes watching furtively the path over the green field beyond the stone wall.

"If he should come now ! I almost hope he will not." This to herself.

"Kate, I must say, you are the strangest girl I ever met. In sober earnest, tell me what you mean."

"Money."

"Money!"

"Yes, scrip, - stamps, - eash. Here you find it for the picking."

"I really don't understand."

"You are dull, my love. Come, be a dear, and help me fill this pail."

Mary stood for a moment on the walk, undecided whether to run away, or do something else.

What else could she do? To run away, and refuse to aid her good-natured sister, would be unkind, at least. To set to work picking berries would expose her to a disagreeable degradation, in somebody's eyes, should they chance to see. Would he, the aristocratic young man, ever forgive her, if he found her at work in the garden? Would he not be shocked, and beat a retreat with no returning? Would he not despise her red fingers and old tin pail?

Vanities of vanities! The complaint of an anxious mind. 
Not altegether a weak one, for its owner did begin to pick a few berries, in a listless manner. Her vanity was not alone to blame. The desire to find favor in love's eyes helped out this rather silly view of things.

A moment after, the reckless Johnny appeared, loaded down with little strawberry baskets, and singing in a loud voice that classical melody, "Captain Jinks."

"Goodness, Johnny! stop that noise," exclaimed Mary, petulantly.

"Noise! That's music. I'm rehearsing last night's serenade."

Kate laughed immoderately.

"Hush, Kate!" said Mary. "You will tell the whole neighborhood. .How can you be so boisterous!"

"Now, fellows," said Johnny, "let's see what can be done. Pick is the word. Ten quarts at least. Leave the hulls on, and top off each basket in a precise and elegant manner."

"Why not take the hulls off?" said Mary. "It must be done before they go to the table, and we may as well do it now."

"No," said Johnny. "They sell better so."

"Sell! What do you mean?"

"I mean we are going to sell them."

"Does your father know it?"

"No; but mother does. We sold some this morning 
and mother says we may try once more, and if we succeed we are to ask father's permission to sell them all."

"Sell our strawberries! Who ever heard of such a thing? I should be ashamed to be seen on the street, were we to do so. It will be the town talk, and all our friends would cut us forever."

"Let 'em," said Johnny. "Who cares? I'm for selling the berries and giving the money to father to pay the coal-man's bill."

"And stay where we are," said the practical Kate, "and not be obliged to move into some little house in some back street. For my part I'd rather pick berries all day than move away. Who is to know of our doings? No one can see us, and Johnny is to sell the berries before anybody is up."

"I am afraid we shall have to pick a long time before we get a hundred dollars," said the despondent Mary.

"I don't know about that. There are heaps of 'em; and then there are the grapes, - we can sell them too. Anyway, we will try."

And so they did. The shallow wicker baskets, opening wide at the top, were soon filled, and Kate and Johnny, with each two baskets, started to carry them to the house. Mary offered to bring the rest, and lingered behind. Shortly afterward, she could have been seen dreamily sauntering up the path, with a far-away look in her eyes, as if she had 
caught a glimpse of delectable, but impossible mountains. Empty-handed, but very happy. How absent-minded young people become under certain circumstances! 


\section{CHAPTER IV.}

THINGS GET EXPLAINED.

The Wellson breakfast-room the next morning. Johnny gazing aimlessly from the window, and wondering how things were going to come out. All the plates on the table turned down, and under one something attractive, but not edible.

Kate appeared upon the scene.

"O Johnny, have you got back? What luck, my boy?"

"Not much this time. Bad fall in the market."

"What! did you tumble down and spill the berries?"

Johnny laughed in spite of himself, and would have explained had not the rest of the family appeared just then.

They all sat down apparently unconcerned, but with all, save Mr. Wellson, in a flutter of excitement. The climax came when Mr. Wellson turned his plate over and discovered a small pile of rather dirty scrip beneath it.

"What is this?" said he. "Did I leave it here last night?"

"No," said his wife. "It was not yours till now." 
"How so? Has anybody been so honest as to make a return on some over-paid bill?"

"No."

"Then where did it come from; and if it is for me, how shall I enter it in my books?"

"Call it new income," said Johnny.

"No," cried Kate. "Call it Johnny's present. Ho earned it, and it is to help pay for coal and things."

"Earned it! Really, he is beginning young. Come, let us have breakfast and talk this thing over. Have we no fresh strawberries to-day?"

"Yes," said Mary, uncovering one small saucerful. "These are for you. We do not care for any."

Mr. Wellson took the proffered fruit, saying, "Ripo fruit is always best at breakfast." After adding sugar and cream to the berries, he paused a moment to count the money as it lay on the table.

"Three dollars and a half. You must have worked long and hard to have earned so much. Tell us how you did it."

Johnny was absorbed in bread and butter, and was " too full for utterance."

"Have you lost your appetite for strawberries?" said Mr. Wellson, turning to Kate.

"Oh, dear, no ; only I don't care for any to-day."

"Neither do I," said Johnny.

"Really this is strange. Strawberries refused, and 
Johnny gone into business about which he does not care to talk."

"The fact is, father," said Mrs. Wellson, "the children have agreed to go without what they call 'their share of the strawberries,' and intend, with your permission, to sell them, and so help pay our debts."

Mr. Wellson's appetite was gone. He did not care to eat any more berries. He paused and gazed into his coffeecup. What he saw there was uncertain, for his eyes seemed very misty just then. He pushed back his chair as if to rise. The impetuous Kate slid from her seat, and planting her liberal self upon his knee, twined her arms about his neck.

"O father, father! We did not mean to do wrong, and - and it's all my fault."

Poor Johnny sank down in his chair nearly out of sight. If he could have disappeared through the bottom of his boots, be would have done so cheerfully.

"No, it isn't," said he, in a solemn voice. "I did it, and I'll tell you about it, if you'll let a fellow."

Mary turned away and stared out of the window very hard. Mrs. Wellson rattled the tea-things and tried to be cheerful.

Taking Kate's face in his two hands, Mr. Wellson looked as steadily as he could into her clear brown eyes. His own were rather dim, and perhaps dewy. 
"Why don't we have a small earthquake?" moaned Johnny.

Kate stirred not, and her father then and there deliberately kissed her pretty lips.

"You are a darling, Kate. I believe what you say. Any man ought to be happy in such children."

"Then you don't blame us at all?"

"No, Kate. I am too much pleased to be anything but thankful and happy."

"Hooray!" cried Johnny, brightening up. "Hooray, dad! We may sell the berries, - may we not? And we can pay the plaguy coal-man, and live in this house still." "We can try," said his father. "I have no objection to the sale of the berries."

Mrs. Wellson breathed more freely, and Mary actually smiled upon her uproarious brother.

Her every hope was realized - if - if the berries brought enough to supply the deficit. Would they? It was an open question, but one worth trying, provided some one never found it out.

All this to herself; for the others, only smiles and a rosy face.

"What pleases you, Mary?" said her father.

"Nothing very special," she replied. "I was merely thinking that if we could stay here how nice it would be." "Come, Kate," cried Johnny, "let's go see about the baskets for to-morrow." 
"I'm with you, my boy."

She was, evidently. With a jolly uproar the two disappeared towards the kitchen.

"What do you think of this, mother?" said Mr. Wellson. "Will they not tire of the experiment in a few days?"

"I think well of it. It will give them something to think about, and a sense of independence and helpfulness, I approve of the whole thing. As for becoming tired, I fear you do not know Kate. If she makes up her mind to do anything it will be done, if possible. As for Johnny, wild boy that he appears, - he is persistency itself."

"I am sure I am very glad to hear it, and hope pride will not lead them to hide their doings."

To Mary this seemed a direct shot at hexself. but sbo wisely said nothing. 


\section{CHAPTER V.}

CONCRINING MRs. GRUNDY - WIDOW.

We must condense. The go-ahead Johnny and the lively Kate took their new work in hand, and, in spite of many troubles, vexations, and disappointments, pushed things with vigor and success.

To be sure, they found it rather hard to be obliged to go to work picking strawberries as soon as they returned from school, and getting up so very early in the morning and carrying the berries through the streets was not equal to base-ball - as an amusement.

Still they toiled on, cheered by the slowly increasing pile of scrip. About the fourth day of their experience a fresh trouble appeared, - an unlooked-for embarrassment of riches. There were more berries than they could pick unless assistance was procured.

Their operations had fortunately begun at the very opening of the season. The warm and sheltered situation of their garden had favored them greatly. Their fruit was ripe several days earlier than that on the neighboring farms. This was the cause of the high price they obtained by their first sales. As soon as the berries began to come in from the surrounding country, down went the price. 
When, on the fourth day, Johnny returned with less money for his ten baskets than he had received before, Kate was discouraged.

"It's too bad, Johnny. Only a shilling a quart, after we took so much pains with them."

"Yes," said Johnny, hopefully; "but look at the garden. Who is to pick 'em all? We can't. They are too thick for us. If the price has gone down we'll make it up by selling a heap more."

"Let's go look at them."

"Let's - , but wait a bit. Hadn't we better call Mary? She hasn't helped us much so far."

"She can't. She has to help at the mending, and you know how hard you are on your stockings."

Reaching the strawberry-bed, both were surprised to see how abundant the crop was.

"Can't help it, Kate. Mary'll have to help us. It will take all my time to sell such a lot of them."

"So I will;" said a voice near by.

"There's Mary, now," cried Kate. "What can she be doing over in the field?"

Johnny didn't know, but guessed 'she would have a hard time climbing over the stone wall. On the contrary, she found, an easy place, and stepped from stone to stone as easily as if she had done it many times before. Perhaps she had.

"There are a good many," said Mary, approaching the 
strawberry-plantation. "We must lose no time. Run, both of you, and bring as many baskets as you can carry." Little thinking how nicely they were sent away, Kate and her brother disappeared towards the house.

"Now if he should come. No, he will not. It is too early. The clock -"

She paused abruptly. The sound of voices from over the high fence startled her. The air was still, and the approaching twilight served to heighten the effect of sound, and sharpened Mary's unwilling ears. Two shrill female voices, talking in gossipy strain:-

"It's the town talk."

"Who'd a thought it of them? I would not, and yet Miss Squoggins was a-telling me how her brother bought 'em of the boy. Says he, 'They were fine berries, - best in the market.' .

"Sho! Well, I thought they'd have to come down. They was alwers a stuck-up set, - specially that Mary. She's a-setting her cap for the squire's son. Guess he wouldn't go that way much, if he knowed it."

Here another and less harsh voice broke in: "I don't believe a word of it. And what if they does? Don't the squire's folks send a can of their extra milk over to the doctor's every morning, and do you think the squire's the man to give his Jersey cream away? Not he. He has a a price, and gets it, or my name isn't Polly Scrabhins. I 
mean to call on Mrs. Wellson and, if I stay to tea, I can tell whether they sell their berries or not."

"You're a sharp un, widder Scrabbins. You're thinking of your own darter, aint yer? She's a-dying for the squire's son, herself."

"La - oh!" -

Just here the noisy Johnny appeared with much clatter of empty baskets.

"Say, Mary, have you been waiting here all the time?"

"Yes," said she, speaking very loud, "I have."

Voices: "Whist! She was a-listening, the minx!"

Mary's face was white, and her eyes fairly blazed. "Give me a basket, Johnny; we shall not get a full crop unless we hurry."

Johnny stared. What a voice his sister displayed !

The three children worked hard till dark, and then with the piled-up baskets returned to the house. As quickly as possible Mary prepared herself for supper, and went to the parlor. As she entered the room she met a faded, thinfaced woman, in dingy weeds, going out.

"The intolerable creature has effrontery enough for a whole sewing circle."

This to herself; for the visitor, only smiles, good-humor, and overwhelming politeness and attention.

"O Mrs. Scrabbins! How do you do? Not going, are you? Won't you stay to tea?" 
"Oh, dear, no, thank you. I must hurry home."

"We can't think of it. You must stay to tea. Come, let me help you take off your things. We shall be delighted to see more of you. You can tell us all the news. We are very quiet here, and seldom know what is going on in the world."

In spite of her protestations the little widow found herself gently taken in hand, and treated to a most splendid strawberry supper. She had never eaten so many nor such luscious berries in her life. With most charming persistence Mrs. Wellson and her daughters plied her with good things, till she was forced to cry, "Enough!"

When the family rose from the table, there was still a heaped-up plate of berries remaining.

The surfeited widow departed, and the careful Kate turned the surplus berries into a basket, saying gravely to herself :

"I suppose our looking at 'em on the table won't hurt the sale."

The days flew by, and the strawberry speculation prospered. Everybody in the house took hold with a will, and not a berry was lost.

The season was drawing to a close, and the fruit grew scarce. In a fer days it would be gone. One morning, as Johnny was trotting gayly home with his empty baskets and singing his favorite melody, "Captain Jinks," he met a young man walking leisurely along the village street. 
The thoughtless boy rattled his baskets in time with his song, and behaved in a generally jolly and uproarious manner.

The young man - a person evidently possessed of some brains and a fair education - glanced keenly at the boy, and then passed on. Turning a corner, he paused beneath a tree, and involuntarily began to stir the gravel on the walk with his heel. Lost in thought, he seemed to be undecided as to what to do next.

"It is unworthy of her. I can hardly believe it. Yet here is her brother, plainly exposing the matter to all the village. Pshaw! It is unworthy of me to think ill of her, or to care if these things are partly true."

Grinding his heel into the gravel he turned and went the other way. 


\section{CHAPṬER VI.}

GOING INTO THE FRUIT TRADE.

Finally the last berry was picked. The trade came to a stand-still, and the new income ceased. Unfortunately the Wellson expenses were increased at the same time for sundry causes : summer dresses, etc.

Mr. Wellson came home one evening, looking tired and dispirited. Not even the helpful wife, nor cheerful children, could drive away the cloud that settled upon their bread-winner's face.

The supper-table, usually a scene of mirth, was sombre enough. Even Mother Wellson's tea, a luxury in itself, was bitter, and the dip-toast unattractive.

"What is the trouble?" said Mrs. Wellson.

"The city thinks it must economize, and has taken away my assistant, without adding to my pay. The times are bad with me."

"Perhaps they will mend soon. Things can't be dull forever."

"I hope not, I'm sure."

Mary searched for something in her teacup, with heavy eyes.

"Will troubles never end?" 
Kate ate her toast in silence and bitterness.

"One must eat, whatever happens."

As for Johnny, he finished his meal and then went to his room. In a moment he returned, bringing an old collar-box, which he gave to his father with a slip of paper.

"There, dad, I hope that will help you. This paper gives the list of the sales, and in the box is the money."

Everybody brightened up. Mr. Wellson took the paper, glanced at it, and with a smile gave it to his wife.

"Really, Johnny, have you made no mistakes? Can it be possible our little strawberry garden yielded so much?"

"Don't think I did, sir. Count the money and see."

The box was opened, and the contents turned out upon the table. Such a heap of scrip and bills! Positively, it looked cheerful, in spite of its unattractive appearance.

"Lend us a hand, girls. Here's wealth for the counting."

Hastily clearing away the tea-things, Kate and Mary busily turned the heap of money over, spreading each denomination by itself, and then carefully adding them up. Johnny stood by, an interested spectator, till the final grand total was announced.

"Two hundred and two quarts sold. Cash: Forty dollars and forty cents. That's about twenty cents each," said Mr. Wellson.

Mary turned away, sick at heart. "Then we must move. 
Only forty dollars! A long way from the necessary hundred." This, meditatively, after her usual fashion.

"I really do not understand it," said Mrs. Wellson. "There is Farmer Gooding, selling strawberries by the hundred boxes a day, and yet he says he never gets more than eighteen cents, on an average."

"I can understand that. Our fruit was more carefully picked, was fresh, and not injured by having the hulls torn off. It had not travelled all night in a wagon, nor lain in a warm store half a day. Nor was it packed in tight wooden boxes, to ruin the flavor."

"And Johnny got fancy prices at first, as there were no native berries in the market," said Kate.

"Yes," added he, "the market men said they were prime berries. So they were. We took pains with them, I'm sure. Didn't we, Kate?"

"Guess we did, my boy."

More discussion was had over the matter, and also concerning the further troubles that had fallen upon the family. A sorrowful, dull, prosy matter, that we will skip entirely. The final result may be of interest.

"We may as well put our pride in our pockets, and do the best we can. Your mother and I have canvassed this matter, and find that we cannot better ourselves by moving; therefore we will remain where we are-but we must reduce our expenses."

"How?" said Mary, brightening up. 
"Keep no servant, and live in a more simple - "

"And raise strawberries," exclaimed Johnny. "Hi! won't it be fun? We can plant the whole place to srawberries."

At this startling announcement the company were completely demoralized.

The lively Kate thought it would be perfectly jolly, and she and her brother at once began to lay plans for the proposed strawberry garden. Even Mary thought that would be better than moving away. So greatly excited did the young people become over this project, that it was nearly eleven o'clock before they sought their respective "downies" for the night.

Mr. Wellson, far from discouraging this idea, gave it his cordial support, and said to his wife, as they were shutting up the house:-

"I shall be glad to have them try it, even if they make nothing by it. It will take them out of doors, give them a healthful employment, and teach them, not only to work, but much useful and valuable knowledge."

The next morning the entire family went out to inspect their garden, and to decide what should be done first.

To understand all their doings, we must take a slight glance into the history of the place.

The estate had been in their hands about four years, and represented the small legacy from the Wellson family property. As has already been described, the garden lay on the south 
side of the house, and was closed in on the east and west by high buildings. The south and only open side admitted sunlight and warmth. A better aspect for a garàen could not be devised. In area, the space, free from trees, measured something more than thirty thousand feet. A row of pear-trees extended across the northern end, and divided the small grass-spot next the house from the garden proper. The omission of two trees in the centre allowed a path to extend straight down through the centre of the estate, and gave a chance for a pretty view from the dining-room windows. At the lower or southern end of the garden the gravelled walk ended abruptly at the stone wall.

For the last four years the place had been used for a kitchen-garden. During the first three years, a gardener, who had planted and tended the crops each season had been employed. The previous summer the entire garden had been planted with strawberries. This season the gardener had not been employed, and the place had run wild with weeds, and presented a forlorn and neglected appearance.

"A sorry-looking place," said Mr. Wellson, when they had all assembled on the path. "The principal crop seems to be weeds."

"Never mind," said his wife, cheerfully; "Johnny is equal to them."

"Guess I am," said he, stooping down and grasping a 
huge dandelion with both hands. "Come up out of this, Mr. Lion's tooth."

It was a double-fanged molar, and refused to stir

"Pull away, my boy, - he's coming!" cried Kate. Johnny struggled bravely. Suddenly up came the weed, and down went Johnny with heels in air, accompanied by a triumphal fountain of dust, to celebrate the hero's prowess.

"You troublesome boy!" exclaimed Mary, brushing the dust from her dress.

"Ha! ha!" cried Kate. "What a pyrotechnical weedpuller you are!"

Johnny scrambled to his feet amid the laughter of the company, and, having shaken himself, displayed the weed, saying:-

"Well, it's up, any way."

"At that rate," said his father, "you will be a long time clearing the place."

"Nevier mind, Johnny. You shall have proper tools, and be saved any further ground and lofty tumblings."

The subject of tools opened considerable discussion, which resulted in a resolve that a part of the forty dollars should be used to purchase a digging-fork, to enable Johnny to clear the place of weeds. While they confessed that they knew little or nothing of strawberry culture, yet this much they did know, - first, clear the land of weeds and stones, of which latter there was a liberal supply.

Immediately after dinner, with a bran-new five-pronged 
digging-fork, light and easy to handle, Johnny began the culture of strawberries. The admiring Kate sat in the little wheelbarrow on the walk, and looked proudly on. As soon as a small space was clear, she procured from the wood-shed an iron rake, and began to gather the débris into heaps. With many struggles, much sweat, and, as Johnny said, "a pretty large tired," the place was partially cleared of weeds. It looked pretty rough and irregular, but was clean.

By the time supper was ready they both found themselves ready to, as Kate said, "slay any amount of bread and butter." The wheelbarrow, which they had not found time to use, was returned to the shed, and the tools put away for the night. Thus ended the first day.

As they entered the house the cheerful fragrance of supper greeted their sharp young noses.

"I'm going down to see what Helen has nice for supper," said Kate.

On entering the kitchen she was surprised to find Helen - the one servant - gone. At the stove stood her sister, looking "good enough to eat," in her nice.white apron and simple dress.
"Hallo, Polly! Playing cook?"
"Yes, in dead earnest."
"Wherefore? Where's Helen?"
"Gone, - for good."
"O Polly!" cried Kate, flinging her liberal arms 
round her pretty sister. "You are a darling - duck of a dear - There's a kiss for you."

"Goodness, child! See what you have done."

"What, dearie?"

"Upset the teapot - and made me burn the toast." 


\section{CHAPTER VII.}

CRLEPING BEFORE WALKING.

THE following day the weeds were all forked out, and lay in heaps about the place.

The next day it rained till quite late in the afternoon. About five it cleared away, and the impatient Johnny trundled his wheelbarrow down the walk, to remove the heaps of weeds scattered round. As he took up the first pile he made a discovery.

"That's queer! Took root again and started to grow in one night. Lucky I began to remove them. Another day and the work would have to be done again.

So it was that our hero began to gather from nature facts both useful and interesting. Of course he never forgot them so long as he lived.

By sundown the weeds were carefully piled up in a heap in an out-of-the-way corner, preparatory to turning them into compost. This, his father had instructed him to do. The latter had obtained the idea from an agricultural paper, all of which goes to prove that he was a sensible man. In the same dark corner, at the end of the row of pear-trees, stood, partly out of sight, a 
common chain pump; beside it, along the fence, lay several long wooden spouts. The use of these will be made plain in due time.

The stones that lay scattered over the ground were also taken up and deposited in a heap by the wall, whero a cart could at some future time call and take them away.

We may here state that the dwelling-house occupied the northern half of the Wellson estate, and that they had no other buildings of any kind, - simply a square two-story house, with an $\mathrm{L}$ attached, such as can be seen by the score in any modern New England village.

Before the house, and extending to the street, was a bit of lawn with a few shrubs. The trees on the sidewalk furnished a slight screen from the gaze of passers in carriages, and a pretty wooden fence shut out pedestrians. Altogether it was a simple yet comfortable home. Home, - that's it. It was home; a place endeared to them all, and we cannot wonder at the Wellson aversion to leaving it. As Johnny went in to supper that night, he found Kate busily examining a pile of books.

"I'm digging into the books, my boy. Learned a heap of things already. Father brought these two from Loring's, and I got another from the Public Library."

"Good for you, Kate! We'll attack 'em after supper."

So they did. Tea being over, the household assembled round the evening lamp, and every one became interested in 
the new project. The three books each had a reader, and the others discussed matters as best they might.

After a while they came to this conclusion: Whatever was to be done must be done at once. The garden was already planted; that had been done the previous season. But what was to be done now? To let it alone they knew was not the thing. Those queer, straggling runners the strawberry will persist in sending out were starting, and no doubt they needed attention. But how to give it?

"I hardly know. You must ask Farmer Gooding, or go out to Mattapanset and see Mr. Harker," said Mr. Wellson.

"That would be fun," said Johnny. "Would you like to go too, Kate? School does not keep to-morrow."

"Yes, I should. I was reading about Mr. Harker's strawberries in the 'Transcript' the other evening. He sells hundreds of boxes a day to the rich folks who drive past his place, and I'd like to see how it looks."

"And if you are bright," said Mary, "you will keep your eyes open, and see how they carry things on there. You may learn something useful. To tell the truth, we none of us know much concerning this matter, and must learn all we can by observation."

"You may trust Kate for that," said Mrs. Wellson. "If there is anything to be seen she will both see and remember it."

Kate's eyes shone, and Johnny patted her on the back, 
saying, "You are a dreadful good girl, Kate, and you shall go with me."

"It's quite proper I should," she replied, in a patronizing manner. "You need some one to matronize you."

Accordingly, to the city, and from thence by horse-cars to Mattapanset, went, the next day, the lively Kate and her wide-awake brother.

The horse-car passed within a few steps of the place. They both got out and walked down a broad street, having an old, dismantled hotel, with its great courts and broad avenues, on one side, and a low stone wall, with market gardens beyond, on the other.

A quiet, sleepy place, having an air of age and decay not often seen in New England towns. There were no manufactories, or even new hous?s about; nothing but the dull and stately residences of retired merchants, gardens, and peaceful farm-houses.

Our two young people walked in silence under the tall trees that lined the way, till they came to a side street turning to the right and leading towards a small, unpretending house standing alone on a grassy hill-side.

Not a person was in sight, and they began to be alarmed, fearing the whole place had gone to sleep, or was away on a visit.

"Dear me!" exclaimed Kate. "I should not care to live here. It's so lonely and dull. Every house in 
sight looks as if it were fast asleep. Mr. Harker's is, at any rate, for it has shut its eyes."

"Nonsense, Kate! There must be somebody about."

"Perhaps so; but the house is asleep. Don't you see all the blinds are shut? I'm almost afraid to ring the bell, for fear it would gape and open its eyes suddenly."

Timidly walking up the broad, smooth drive, they approached the house and looked about them. Just beyond the house stood a neat barn and shed. Everything was clean, prim, and sober. The lawns on either side were smooth, and even the wide-spreading strawberry beds that crowned the hill, were as straight and regular as if prepared for the most precise private grounds. No appearance of business or farm life was to be seen. All was finished and elegant.

"We ought to have wiped our feet on a mat before we entered the drive-way," said Kate. "The road is as nice as a kitchen floor, and the grass is like a parlor carpet. But, dear me, how sleepy it is! Now I suppose we must ring, whatever happens."

Johnny was on the point of ringing the bell, when they saw a man leisurely walking over the grass towards them.

"Mr. Harker," said Kate. "Don't ring, Johnny." The man saw and advanced towards them: a stout, wellbuilt person, with a sun-bronzed face that at once indicated strength and brains, - a gentleman and a farmer. Higher 
praise cannot be given. His eyes were blue, and full of good nature and kindness.

The usual greetings were exchanged, and Kate having briefly stated their mission, the three crossed the smooth grass towards the strawberry beds that spread out fair and wide over the hill-side. They were several acres in extent, and all in one continuous piece. One portion appeared to be new, as if but recently planted, while the other part was thickly matted with vines, having narrow paths at equal distances cut through it. All around in a wide border stretched the-green and level grass. This gave to the strawberry plantation an air of finish and elegance, while it took away all appearance of business; yet the whole thing meant business, and nothing else. It was cultivated for profit, and for that alone. The combination of the sweeping lawns and regular strawberry beds was artistic, and according to the best rules of landscape gardening. It accorded with the surrounding estates, and served to show that gardening need not of itself be altogether unlovely and rude.

"Now, Mr. Harker, tell us all about it. We have come to learn, and want to see everything that will be of use to us."

"To see all, Miss Kate, would take a year. We can only examine those operations now going on. The rest $I$ must tell you as best I can."

"That's very kind in you, I'm sure. To begin, why 
are these planted so wide apart? The space between the rows in our garden is not half so great."

That part of the plantation they had now reached was set with young strawberry plants standing in long rows. Each row was six feet apart, and the plants twelve inches apart in the rows. The space between was bare, and had apparently been recently cultivated.

"Here," said Mr. Harker, "you see the first step in the business; say, rather, the second step. The first consisted in preparing the ground, by ploughing in a liberal supply of decayed stable manure, and then reducing the ground to a fine surface by repeated harrowings. Then in the damp, cool weather of early May the plants were set out as you see. Since then the horse-cultivator has traversed the ground occasionally, to keep it mellow and clean. Do you understand it all?"

"Nearly, sir," said Kate. "I do not know how you set out the plants. Our gardener did that for us last August, and at that time I cared nothing about it, and did not even take the trouble to see him do it."

"The mere setting of the plants is very simple. Having procured the plants, and cut or torn away the old runners or leaves that may cling to them, set them in the ground in any way your ingenuity may suggest. The whole affair is so simple any bright boy or girl could do it at once, provided they understood this one principle, - to have the roots placed in a hole sufficiently large to receive 
them without crowding or bending them out of their natural shape. The size and depth of the hole will be decided by the size and length of the roots. For tools use your hands, or a trowel. The soil ought to be deep and mellow, and if it is so, plunging the hand into it, and setting the plant firm and upright, will be neither difficult nor disagreeable."

"I should think it would be fun," said Johnny.

"It is certainly not hard. Boys, or women, do it quite as well as the best of men. The German women I employ do nearly all the work, except holding the plough or spreading manure. That is beyond their strength. There are several ways of making the hole into which the young strawberry plant is set. One is to punch a hole with a blunt-pointed instrument called a "dibble" or "dibber." It is nothing more than the handle of an abandoned spade cut off and sharpened to a point. With it, plants may be set out at the rate of two a minute. I do not think it the best way, though it is much used by foreign gardeners. It crowds the roots into too small a space, and does not leave the ground smooth. Another way is to scratch out with a hoe a rude trench, into which the plants are dropped, and then the hoe is used to cover them. This might be called the lazy man's method, and, though often successful, I cannot recommend it."

"Then our gardener must have used a hoe, for here and there a plant is missing, and the rows are broken." 
"They were set in August, you said?"

"Yes, sir. It was very warm weather, and I remember he had to water them often, to keep them from dying."

"That was the cause of the failure. There is but one time in the year to plant strawberries, and that is the spring. Many people think differently, but my experience leads me to plant only in May. So strongly am I impressed with this, that I now refuse to sell plants in the fall, as I know the result will only be a loss of both plants, labor, and temper. Fall planting is possible, but spring planting so superior, that I sometimes wonder any one ever attempts any other. Then the fact that the plants are only saved, when planted in the fall, by liberal waterings, is an objection. If a plant will not flourish of its own unaided strength, it had better die. It is a poor thing, not worth the keeping. In May, watering is not required." -

"Now," said Kate, "you have reached our case. Our plants are set out, and they look precisely like these. Long rows of plants just sending out runners."

"Except, Kate," said Johnny, "that our rows are twice as thick."

"Then you had better pull up every alternate row, so that there will be a space of six feet between them."

"Will they ever cover such a wide space, Mr. Harker ?"

"No; you must leave a path in the middle, three feet wide and quite bare. This may seem extravagant of space; but, in my experience, the plants become so large, and hang 
over the path so much, that the pickers tread upon and destroy more berries than the space is worth. I began with narrow paths, only to extend them a little each year, till now they are, as you see, three feet wide."

Just at this point a man appeared, leading a horse harnessed to a narrow stone roller. Behind came a couple of bronze-faced German women.

"Now," said Mr. Harker to the children, "you can see the next operation. You will notice that the entire six feet of space is bare, and that the runners are crowded up against the plants. That was caused by the cultivator. As it passed over the ground, it swept the runners one side, and they clustered about the plants unharmed. The next thing is to mark off a space three feet wide in the centre. This is done by the roller. It is just three feet wide, and, as it is dragged along, it rolls the ground down smooth for the path, and marks the place where the new plants are to be set. This having been done, the women come after, and, selecting a strong runner, pin it down to the soil with a small stone, so that the new plant, when it takes root, will stand opposite, and just eighteen inches from the old plant."

The horse stepped into the ploughed land, and the roller went trundling down the hill, leaving its smooth track behind. Then the women placed quickly and accurately a runner at the edge of the path, and opposite each old plant. A little arithmetic will show that the edge of the walk would be just eighteen inches from the rows of plants, so 
that it was an accurate and easily made guide to the workers.

"What will you do with all the other runners?" said Kate.

"Cut them off. As you see, each woman has a pair of small scissors, and snips off all the runners except the two that are to be spread out on either side."

Johnny gazed earnestly at these things for some time, and then said : -

"I see what it is. This is hill culture. One plant standing alone and all the runners removed, - and - but no, - it is not quite that, after all, for you do take two runners."

"I don't wonder you are perplexed," said Mr. Harker. "This is a combination of the two plans, - hill and field culture. Hill culture means, as you say, that each plant stands alone, and is deprived of all its runners. The people who practise it claim that the strength of the plant, instead of being wasted in bearing young plants, is saved, greatly to the advantage of the expected crops. In using this method, they usually set each plant out by itself just where it is to stand.

"In theory they are right. Cut off the runners, and the crop is larger and finer. I practise hill culture, with this slight difference, $-I$ do not set out all the plants at once. I set but one in three, and take from the one the tiro that are to follow. This is not enough to hurt the plant, 
and the two new ones find a mellow, warm soil to root in. The advantage of free horse culture more than offsets the extra labor of pinning down the new plants. As for removing the other runners, that would have to be done in any case."

Kate and Johnny felt sure that they now understood the matter, and were prepared to practise it on their own account. They stood for a while watching the two women deftly setting the expected plants, and then passed on over the hill to where further operations were being carried on. Coming to a place where a man was at work, they were surprised to find him planting turnips, right in the middle of the paths cut through the strawberry beds. The plants in these beds had just produced their second crop, and were thickly matted together; the great broad leaves covering all the space between the plants, and even encroaching on the wide path.

"There," said Mr. Harker, "is a number of beds that have produced fruit twice, and are too much exhausted to be worth further culture. I now have the centre of each path planted with turnips, or some other crop, and when the time comes to cultivate it, I put in a light plough, and turn the strawberry plants and all right under. The plants decay, and by fall the ground is ploughed over, and all is smooth and clear, and ready for next spring's crop, whatever it may be. I can again plant strawberries, sow it down to grass, or plant root crops. To set it again with strawbcrries would be 
the least profitable way, as a change in the crop is best for the land."

"Were you to use strawberries the next year, you would get no return for your land?"

"No. It produces nothing, while the plants are growing. To offset that, I get three crops the two next seasons, - two of berries, and one of turnips, or something else."

These, and many other matters, the children examined with interest. To tell of all they saw and heard would involve more time than we have at command. Their after experience in the care of their own strawberry garden must explain so much as concerns us. They spent several hours with Mr. Harker, visiting his splendid great barn, on another part of the estate, the pear orchard, and vegetable gardens. Everywhere they went, neatness, order, and thrift greeted them. The plants and trees were models of their kind, and, as for weeds, they were not sure that they saw even one. Like good children they went home early, and reported to the assembled supper-table all of their doings and hearings at Mr. Harker's, in the sleepy old town of Mattapanset. [See Appendix A.] 


\section{CHAPTER VIII.}

HELP WROM A NEW QUARTER.

The next day, 11 A.m. Kate and Johnny in earnest consultation in the strawberry garden. Every alternate row of strawberry plants had been pulled out, and there now remained thirty-six rows, each about two hundred feet long; the space occupied by the garden being about thirty thousand feet. The removal of the extra rows was a trifling matter, and quickly accomplished. The remaining ones were more or less damaged, - a plant here and there missing. To extend the runners, now quite long, on either side was easy enough, but to repair the breaks puzzled them.

"I'm sure I can't fix 'em," said Johnny. "There are six plants gone in one row."

Kate replied that it was beyond her.

"We might pull a runner round sideways at each end of the gap; even then there would be four plants still wanting."

Just at this point who should appear but Farmer Gooding, a "truck farmer" living about a mile up the road. He was dressed in his common blue frock, and came striding down the walk, whip in hand, in his usual energetic manner. 
"Good-mornin', children. What ye 'bout?"

"Good-morning, Mr. Gooding," said Kate. "What can we do for you?"

"Oh, nuthing, nuthing, thank ye. I was at the house and saw ye at work and came to see ye. What ye doing?"

"Setting the runners on the strawberry plants."

"Law! bless ye! Do ye take all that trouble? Mine have to set themselves. 'Twould take more than a month to set mine. They are too thick. I let 'em run where they will."

"Do you think it is the best way?" said Johnny.

"Well, yes - ginerally. I s'pect they do bear more by cutting the runners; but I never could come down to such fine knitting-work. It don't pay."

"Mr. Harker thinks it does," ventured Kate.

"Mebbe so. Folks is different."

With many comments on what the children were doing, the stout, burly man strode about the ground, examining closely all that was going on.

Seeing one of the sad gaps in the rows, he said:-

"You can mend that in the fall. Let a few plants run, and then pick 'em up and set'em in these spaces some rainy day in September. Fall planting is ginerally no use, 'cept ye take all the pains in the world. Hallo! Grapes need pinching, bad."

By this time he had reached the fence where the grape- 
vines were hanging luxuriously from the trellises. The young fruit was just forming and the green and vigorous shoots hung thick and tangled, or waved freely in the wind. At the top of the trellis the vines were boldly climbing the fence, and threatened to invade the neighboring gardens.

"This won't do," said the farmer.

"What?" said Kate.

"Ye must pinch 'em. Ought to have been done before. See - "

So saying, he with his fingers broke off a green shoot about a foot long.

"There. Ye must break, not cut, away the ends of the shoots that have fruit on 'em, at the second leaf beyond the last bunch. It keeps the vine from wasting its strength on the wood instead of the fruit."

The children did not quite understand it all, and their instructor pointed out to them that the fruit was hanging on green shoots that had grown out of the old stalk, or cane. The two or three bunches hung close to the main cane, and beyona them the shoot extended for a foot or more. Were it suffered to grow as it pleased, the shoot would extend to an inordinate length at the expense of the crop. To prevent this waste of strength it was "pinched off" at the second leaf beyond the last or outermost bunch, and all further extension prevented. Growth would not cease, and, instead of a long, thin, valueless shoot, they 
would have larger and better fruit growing upon a stouter cane. Every way a better arrangement.

Kate and Johnny were at first surprised at the audacity of this proceeding, and positively alarmed when Farmer Gooding advised them to go over the whole trellis and serve every bearing shoot and all the top or end shoots in the same way.

"It's the only way. Ought to been done a month back. There'll be a decent crop there, if ye 'tend to 'em."

Kate and Johnny declared they certainly would do so, and soon after, their new instructor went away, careless that he had sown good seed in ready ground.

"So queer!" said Kate. "He does not like knittingwork, and yet he pinches his grapes."

To give the details of all the horticultural doings and sayings of the Wellsons' would involve more time than we have at command. In brief, they went over their little plantation, and with infinite pains did all they could to carry out the directions they had received. Johnny plied his hoe vigorously, while Kate and Mary assisted, with an old pair of scissors, in cutting away the extra runners, and blunted their pretty fingers in "pinching" the grapes.

Did they not find it hard work? Oh! of course. That was the very thing best for them and what they wanted. Good, healthy out-of-door work, if not in excess, is the best thing ever given to three such sensible young folks as these same Wellsons. 


\section{CHAPTER IX.}

\section{HYDRAULICS.}

IT was a cool, bright day, with flying clouds and a fresh breeze. Nothing had been done that day in the Wellson strawberry plantation and all was quiet.

The young plants stood fresh and stiff in their thin rows, and the horticultural prospect was smiling.

About four o'clock John, Jr., appeared upon the scene. Gravely walking up and down the gravelled path he studied the plants, the sky, and the white masses of clouds piled up in the west and north-west. After a while he said : -

"Going to rain 'fore night. Shouldn't wonder if we had a thunder-storm. Wind's north. Couldn't find a better time if I tried."

Walking around the house, he went out upon the village sidewalk. Here he had a better view of the northern sky.

"It's coming, sure. Guess I'll begin."

Without further thought he went to the chain-pump that stood in the corner of the garden by the fence. Here, from the ground beside the fence, he took a long wooden spout, made of two boards nailed together $V$ fashion. Placing one 
under the spout of the pump, he laid the other down between the rows of strawberries. Then to the pump. Grasping the handle he began to turn it rapidly. A thick, inky current of water flowed forth and rushed in a muddy stream through the spout, and then spread itself slowly down the slope of the garden, among the plants. A strong odor arose, but as the north wind blew fresh past the house and out over the empty fields, no inconvenience resulted to anybody.

As the black stream spread over the garden, it rolled sluggishly down the slope and finally reached the end of the place. Seeing this, Johnny ceased his efforts, and, procuring a hoe, quickly made a little dam in the stream, and by a bit of hydraulic engineering turned the course of the black river to the next row of plants.

Again the crank was turned, and the turbid water gushed forth and flooded still more of the plantation.

So it went on. Each time the stream reached the foot of the slope a new channel was formed, and the flood directed elsewhere. As can be easily seen, this operation was a species of irrigation, only, instead of pure river or spring water, he used a richly ladened stream full of plant food of the most valuable kinds.

One side of the garden having been thus freely flooded, more spouts were procured, and joined one to another they carried the life-giving current across the path and on to the other bed. 
Just as it began to flow in the new direction, the clouds threatened rain in real earnest; the thunder muttered.

"Good!" cried John, Jr. "It's coming. Providence is on my side this time. The rain will wash it in finely."

The thunder pealed louder, and a few big drops pattered down. The crank flew round, and the black river spread in widening floods over the ground. The lightning flashed and the thunder pealed at the same instant. The storm was at hand. Still the sturdy John, Jr., maintained his post. When the current was to be turned, he plied his hoe with speed and dexterity; he also turned the crank swiftly, and pushed his hydraulics with vigor and success. Just as the stream flowed down the last strawberry row, the storm burst upon him. The dust from the road swept like a whirlwind down the place, the pear-trees bent before the blast, and the rain came down in a flood. John, Jr., made a vigorous push for the paternal mansion, and just escaped a plentiful ducking.

In - a short time the shower passed over, and he went out to see what was the result of the combined artificial and natural hydraulics.

All traces of the irrigation were gone, - swept away by the rain; yet the desired result had been obtained, - the plants had been fed.

The next day the ground was lightly stirred with a hoe, and everything made smooth and sweet again. For that matter, no unpleasantness could be discovered by the time 
the shower had passed. The soil acted as a disinfectant, and absorbed both the water and odor.

The cistern built to catch all the wastage of every kind from the house and the pump, to spread in a harmless and perfectly proper manner over the land, made the secret of the Wellson success. Without this weekly application to the plants, such a garden, and bearing such crops, would have been nearly impossible. To the chain-pump they owed everything. The great principle, "Waste not anything," as here applied, is the one secret of all successful horticulture. If all the refuse of each dwelling in the land were as carefully saved and returned to the soil, the barren hills of New England would vie with the prairies in fertility, and millions upon millions of money, that now flows into our seaports and rivers, would reward the toiling farmer, or gladden the patient gardener.

As it now is, we waste and abandon each year more than enough to support every living creature for life, were it all returned to its proper place, - the soil.

One of the chief objects in writing this book is to illustrate the value of this much-neglected principle, - "Waste not anything," - and to show a way of preventing it. [See Appendix B.] 


\section{CHAPTER $\mathrm{X}$.}

UPS ANDD DOWNS.

THE weeks flew away, and September arrived. The green grapes turned purple on the vines, and the strawberry plants grew apace. Frosty nights threatened to cut off the grape crop; but happily it escaped. The warm, sheltered situation caused the berries to show color several days earlier than in the surrounding country, and the first ripe bunch was gathered one Saturday noon by the impatient Johnny, as soon as he returned from school. It was a fine large cluster, and beautifully covered with bloom. Taking it to the house, he showed it in triumph to his sisters. Mary merely glanced at it, and then went on with her sewing. She was dull and listless then, and did not seem to care for anything in particular. The garden was a sorrow and trial to her. The less she heard of it, the better. Had it not ruined her every prospect? Ten days had slipped away since she had seen him, and no word or sign had she received in all that time. It must be that he had been driven away by seeing her at work in the garden with her brother and sister.

Not so with the lively Kate. 
"You don't mean it, my boy! Ripe already! What are you going to do with it?"

"Use it for a sample. Take it round and show it to the dealers as a specimen of our crop."

"So I would. I'd go this afternoon. You can have my lunch-basket to carry it in, and I'll line it with soft white paper, so that it will look extra fine."

"Good for you, Kate! I'll start right after dinner."

He did so. Trotting gayly along with his basket he little hoeded the passers, or what they might think of him. Entering the first provision store he came to, he displayed his sample bunch of grapes, and offered his crop at market rates, whatever they might be. The man in the store questioned him concerning his fruit, and told him to bring a bushel of them as soon as they were ready.

"What do you mean to pay for them?"

"Can't tell. See how they look, and how the market stands. Western grapes will be here soon, and then they will be cheap enough."

Johnny mentally hoped that the western grapes would stay away a few days. On entering another store, he met with nearly the same experience. They would buy them if as good as the sample. Feeling highly elated at the prospect of the market, he thought he would treat himself. He had worked hard all summer, and virtue should be rewarded. He would indulge in a few peanuts.

An ancient female, of Irish descent, commonly sat at the 
foot of a certain tree, knitting a stocking, and tending her little fruit-stand. To her he turned his steps. Arrived there he was surprised to find quite a number of people collected around the spot. Pushing through the crowd, he discovered the peanut stand gone, and in its place a huge hamper piled high with fresh grapes. The old woman, usually so quiet, was all activity, weighing and selling her fruit to an eager company of purchasers. In a moment or two all were supplied, and there was a lull in the trade. The western grapes had come.

"Say, granny, where are your peanuts?"

"Peanuts! Why would I have peanuts when the grapes is come?"

Johnny was struck with a new idea, and the saleswoman turned to another customer. This was a young man, who, as soon as his purchase was made, turned to go away. As he did so he caught sight of Johnny. He paused and then said :

"Is your name Wellson?"

"Yes, sir. John Wellson, Jr. What's yours?"

The young man did not reply, but fumbled in his pocket for something.

"Could you do me a favor?"

"Guess I could, if it is not holding horses or running errands. Don't like to go errands."

"It's nothing very severe; merely to give this note to Miss Wellson." 
Johnny took the delicately scented little note held out to him and turned it over gingerly.

"Oh! it's for sister, is it? I'll give it to her. I'll put it in the bottom of my basket."

So saying, he opened his basket and displayed his one bunch of grapes.

"Them's foine grapes, honey. Do you want to sell sich?"

"Yes," said Johnny, bravely. "I've got a big crop. They will be ripe soon."

"I'll give ye tin cents a pound for 'em, honey."

The young man stared at the two, and then turned away.

"So it is all true. Here is the boy exposing his doings without a blush. If so much is true, it may be all true."

Speaking out suddenly: "Here! young Wellson, let me see that note again."

But Johnny had gone. Delighted to find still further market for his fruit, he had gone home, swinging his basket as he went.

Arrived there he went to his sister's room. She was not there.

"Gone out," said Kate.

Johnny dived into his basket for the note. Alas! it was not there, - lost! 
Johnny's mental atmosphere was depressed. Had we been able to put a barometer into his mind we should have found that it sank rapidly, and finally stood very low. 


\section{CHAPTER XI.}

WTNTER - HORTICULTURALLY AND SENTIMENTALLY CONSIDIRED.

To be brief, our Johnny, with Kate's assistance, gathered and sold their crop of grapes. The hydraulics indulged in during the summer had greatly stimulated the vines, and the warm and sheltered situation ripened the fruit quickly and thoroughly. There were about forty vines in all, and, fortunately for Johnny, the gardener formerly employed had taken good care of them and they were in fine condition. They covered the fence on both sides of the garden, and hung heavy with fruit.

Our hero was much perplexed to decide between the various stores that were ready to take the grapes. Some would pay one price, some another. One man only wanted a few pounds a dar, and another the whole crop, provided it was low-priced. Even the peanut woman wanted a few pounds.

The whole family sat in council upon the subject, and it was decided that, as the children had but little time to spare from school, it was best to get rid of the fruit in the quickest and easiest way possible. To be sure, by running about a little, better figures could be obtained, yet time was worth something. 
So the market-man who took the strawberries had the entire crop, sending a team to take it away, and paying ten cents a pound for the lot.

It amounted to four hundred and fifty-two pounds, which, at ten cents, would be forty-five dollars and twenty cents. This, if we consider the matter, was not a very large result; there being forty vines it averaged only a little over ten pounds to a vine. A fair produce, and no more. Another year's growth, and still greater care in culture, might produce something better.

However this may be the proud John, Jr., was content. The desired hundred dollars had been nearly touched. Upon a sheet of note-paper he made out a statement of the summer's work and the grand result.

Here it is:-

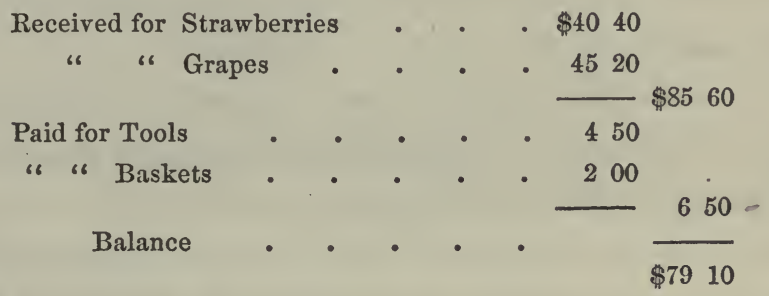

In view of this result the Wellson family resolved to stay where they were. The deficit had been made up. The lessened expense, brought about by dispensing during the summer with Helen, the maid-of-all-work, and the fruit crop, tided them over this shallow place in their lives and 
all went smooth again. Not all serene, however. Mary was ill. As the fall burned away into the winter, and the trees exchanged their green and gold for sombre gray, she, too, seemed to droop and fade. Helen was taken back again, and the family doctor privately asked to give his opinion. He was puzzled at first. Then he said, "Her digestion is good and her pulse quiet. She is well physically; how she is mentally, could not say. Should jadge something disturbed her peace of mind."

Something did decidedly. The note lost by the careless Johnny, and the sudden discovery of a certain trunk marked for foreign parts at the door of the express office, as she passed one day, combined with a mysterious silence on the part of some one, and a more mysterious and indefinite something in the social atmosphere about her, drove her in upon herself, and she became possessed of a spirit of unrest and melancholy.

November arrived, with frosty nights and dull, cold days. The leaves fell from the grape-vines, and the strawberry-vines turned dark and dry.

The first most important thing in the horticultural programme for the season was to prune the grape-vines and lay them down for the winter.

"I'm sure I don't know how to do it," said Johnny, as he contemplated the tangled mass of vines scrambling over the fence. 
Kate was there, and, girl-like, said, "Ask somebody. There must be a way, somehow."

"No doubt. Lots of ways. 'Cording to the books. there's a dozen."

"Let's take the easiest. Let me get the book, and perhaps we can make it out by comparing it with the vines."

Kate procured from the house a work on the culture of the grape, and began to study it carefully.

"Bless me! I can't make anything of it. There are all sorts of directions about cane-pruning, fan-pruning, and a dozen other distracting things."

"Let me see," said Johnny. "Are there not some pictures? They will help us more than any amount of reading matter."

"So they will. See!"

Opening the book, Kate displayed two simple cuts. One marked "fan-pruning," and one "spur-pruning."

"That's him! Fan-pruning!" cried Kate. "Don't you see that is the way the gardener did it last year? See, there are the three sticks, - these." And she pointed to three, stout, radical arms, reaching from a common root, and spreading in a fan-shape over the trellis that was fastened to the fence.

"I don't see 'em, Kate. The thing is one grand snarl and jumble of crossing vines."

"Yes. There they are: Don't you see they are bigger 
than the others? And - " she paused to examine the vine closely.

"And there are the little stumps on them as in the pictures. See, the small shoots grow right out of them each time. Give me the knife. I know how to do it."

Johnny stood lost in wonder, while the bright Kate slashed away in her impulsive style at the vine. The long stems fell about her, and in a moment the tangled mass of twisted vine was reduced to three simple stalks, or canes, about five feet long. Up and down each one she allowed the stumps of the side shoots to remain. Upon each was one or more plump buds. She did not notice them, and though the method she had pursued was a correct one, yet she had chanced upon it almost by accident. The picture had given her the idea in part, and a shrewd guess did the rest.

Johnny gazed at the denuded vine, and then at the book. "Hooray! Kate. You've hit it! Now let us see you do it again."

"Come on, my boy."

Proudly swinging her knife, she advanced to the next vine. Here was a superb tangle. A perfect thicket of interlacing shoots struggled about the trellis.

Kate paused, appalled at the prospect.

"This is a tough one, Johnny."

"Thought you'd be puzzled. I can't see how they do it, for the life of me." 
"Can't see what?" said a voice near by. Tuming round they beheld their sister.

"This plaguy pruning. The book says it must be done in the fall. It's time now, and I can't make anything of it."

"Let me see the book."

Johnny handed the open book to Mary, and she began to study it intently.

"It is rather obscure. The writer seems to think we know all about it; whereas, we know nothing."

"Any way," said Kate, "I did it once, and made it look just like the picture."

"So you did; but still I don't understand it. Let us read more. We may find something yet. Here's a chapter on pruning. Let me study it."

So she did, and all to no purpose.

Johnny and Kate stood idle for a while, and then Mary said slowly, "I think I see through it."

Reading, - "The grape produces its fruit upon the wood of the current year. This grows upon the wood of the previous year. Therefore, in pruning, cut back to a good bud near the old wood. That is say, I suppose, the bunches hang on wood of the current year, whatever that may mean."

"That's simple as pie-crust," said Kate. "See, there is a bad bunch still hanging on the vine. The shoot it grows upon must be what they call the current year's wood." 
"I don't see what currants have to do with it."

Kate laughed. "You are a little goose, Johnny Wellson. Current year means this year."

"Oh!"

"And if I remember," said Mary, "when we were pinching the shoots last summer, I noticed that the bunches were hanging on the green and tender shoots that grew this season."

"That's it! That's it!" said Johnny. "They are brown and stiff now, and all look alike. No wonder we could not tell 'em apart."

"You are right. Now to work. The book says: 'Cut back to a good bud near the wood of the previous year.' In this fashion, I suppose."

So saying, Mary took the knife and lopped off the shoot upon which the yilted bunch was hanging.

"You've done it," cried Johnny. "See! there is the little stump as it is in the picture."

The three crowded round, and discovered that, in cutting the shoot, about three inches remained growing on the stout stem from which it had started.

"Wouldn't it look better if it were cut off close up to the old wood?"

"Why, no, you would cut away the bud out of which the shoot that is to bear next year. is to come. Now, according to my idea of it, all we have to do is to keep cut- 
ting away the shoots till we have only the thick canes or stems that grew last year, or the year before."

Without further parley, Mary plied her knife quickly, and soon displayed before their astonished eyes, not a fanshaped vine, but one having a single stalk dotted up and down the sides with little projecting spurs, or woody points. Each spur had a cluster of buds about it, giving assurance of a bountiful supply of bearing shoots for the next season.

"Why!" exclaimed Kate. "I don't see what that was for. Why did not the gardener train them all fan-fashion?"

"I'm sure I don't know; but it is plain he did not, for you can see that but one shoot grows from the root."

The next vine was attacked, and proved that it, too, was only a single cane.

"It seems the gardener trained our vines in two different ways. I can't imagine why."

"Was it not to gain room? These two are planted close together at the end of the fence. Perhaps there was not room for a fan-shaped one."

"You are right, Kate. That solves it. But come, it is getting dark. We can do no more to-day."

Mary led the way, and Kate and Johnny followed after.

Kate to her brother in a whisper: "Polly feels better to-day."

"Course she does. Went out and did something. Nothing like working round out-of-doors for some folks."

Johnny was a philosopher. There is nothing like healthy 
labor for minds disturbed by much brooding over disappointment.

The next afternoon Kate and Johnny trimmed all the vines, and untying them from the trellis, allowed them to fall to the ground. (This trellis was attached to the fence to keep the vines away from the wood-work.) Then, copying the directions in the book, they fastened them flat to the soil, with pointed sticks driven down in this fashion - $X$

Here they would be secure from the wind, and buried safe under the snow when it came. Nothing more to be done to them till April.

The writer sincerely hopes that in describing this pruning experience he has made the matter plain. There are many other ways of training and pruning the grape; but these he considers the most simple, and, for general use, the best. Should the reader prefer to grow his grapes to poles, instead of against a wall or fence, the single-cane plan will be found the easiest and best. If the vines are scarce, and fence-room plenty, the fan-shape would be preferable.

Should the reader reply that he has no grape-vine of any kind, we can only say, get one. If you have no spot of ground to grow it in, cut an oil-cask in two, bore some holes in the bottom, and, procuring some soil from the nearest florist, grow it in that. Whatever you do, plant a vine.

With the arrival of cold weather the ground froze up tight, and the season's work seemed finished. Yet one 
thing more remained to be done. Hiring a horse and hayrigging, Johnny drove to the woods to gather leaves. He hired a boy to help him, and in the course of a day they procured dry leaves enough to cover the entire plantation. A load of loose brush was added, and the next day the plants were covered from sight, and the brush spread over all, to keep everything safe from the wind.

The entire expense of this operation was just six dollars.

The intelligent reader here wonders why this covering was delayed till the ground was frozen. If the leaves were to serve as a blanket to keep the plants warm, why was it not spread before cold weather?

Simply because it was not to keep them warm, but cold. The shelter was not used to ward off the cold, but the heat. Having become well frozen the leaves were used to keep them so. It is not the extreme cold that injures, but the varying heat and cold of our uncertain climate, the bright sun thawing out the soil one day, and the biting north wind freezing it the next; this alternate expansion by heat and contraction by cold is the cause of all the mischief. Better let them freeze hard, and then stay so till the warm weather really returns.

A few days after these things the snow flew and winter began without.

Within too. Our Mary did not seem to improve. She 
kept her room persistently; and refused every social invitation.

"Ah! that careless, careless Johnny, to lose that precious note!" was her constant burden. But what mattered it? He, the absent one, wandered in unknown parts, and no sign or word had she received explaining his abrupt and mysterious departure, or even telling where he lingered. The garden had proved efficient in assisting them to maintain their position in society; but, alas! at what a heavy cost had it been accomplished.

The snow lay thick and cold. December days were. dull and dark. It was cloudy within and cloudy without. 


\section{CHAPTER XII.}

THINGS WAKE UP GENERALLY.

The winter slipped away and spring advanced. The Wellson prospects improved slowly, and things looked brighter. The returning sun seemed to revive all nature, and men became more hopeful and cheerful as the earth laid aside its snowy raiment and made up its face for a smile. Warmer airs from the far south stirred the snowdrops into life, and brought to Mary vague hints of coming joy. A bird sang in the pear-tree by her window. Perhaps it was a messenger from him who wandered. She flung up the sash to hear the new "spring song without words." Down in the garden she could hear the active Johnny at work in his strawberry plantation. She would go down and get a breath of the sweet air, and see what her brother was about.

When she reached the garden she found Kate there also. Not an idler in the land either. She, stout and rosy girl that she was, illustrated the advantage of an out-of-door life, both in person and cheery good nature.

"O Polly! have you seen 'em? Such splendid green shoots bursting through the ground. I can almost see the young blossoms. Look!" 
Throwing down the armful of sticks she held, she brushed away the leaves, and displayed one of the brown clusters of leaves where a strawberry plant had stood. From the centre a tiny green point thrust its head through the soil.

"Very good, though I don't see the blossoms."

"I did, I'm sure. I saw a plant that had one. Oh! they are coming, I know, and we shall have a mighty big crop."

"What language, Kate! How can you?"

Kate never replied, but gathering her bundle of brush together marched away toward the house, talking the while.

"Oh! I know we'll do it this time. We will get our hundred dollars sure - and the grapes - and the pears; perhaps they will bear this year, and then - then we shall not have to move this year. Aren't you glad, Polly? I am."

"Yes," said Mary, listlessly. "It will be well, I suppose."

"You don't seem to care much."

"No, I do not."

Kate disappeared with her load, and Mary turned to Johnny.

"What are you doing?"

"Gretting ready for the spring. Aren't you glad it's come, Polly?" 
"Yes," faintly.

"I am. It's awful jolly to have the snow go. The strawberries will be here soon; besides, its good weather for base-ball."

Johnny went on gathering up the leaves with his hands and crowding them into a basket. They were wet, heavy, and far from easy to handle.

"Why do you do that? I should imagine they would serve as a mulch."

"Mulch! What's that?" said Kate, just returning.

"Anything placed on the ground around or over plants. The leaves were a.mulch. When the berries ripen you will have to spread a mulch over the soil to keep them clean. That's why they are called strawberries,berries that grow among straw, as straw was first used as a mulch."

- "Hear the girl!" cried Johnny. "One would think she had eaten two whole books on strawberry culture. Why did you not give us the benefit of your learning before?"

Mary confessed that she had only read that much quite lately.

More discussion ensued, and they decided to let the leaves remain where they were.

Johnny went carefully over the bed and brushed away the thickest of the leaves around the plants, to give them a better chance to push through. The surplus was spread 
in the paths, to keep the berries clean. The rains of winter had beaten the leaves down flat, and they made a smooth, clean carpet over all. This prevented any cultivation of the soil; but the advantage gained by keeping the weeds away and the soil moist, more than restored the balance.

Insensibly, the fresh air and new objects and interests had their effect upon our Mary, and she became brighter and better.

The spring advanced rapidly, and every plant started into new and active life. As soon as they were fairly started, and about the time the forest trees put forth their leaves, the hydraulics were resorted to frequently with most astonishing results. How the things did grow, to be sure! Such splendid leaves and sturdy clusters of buds! Really, the prospect was very encouraging.

The grapes, too, came in for a share of the attentions of our trio. At the suggestion of Mary, they removed the stakes, and fastened the long base shoots once more to the trellis. It was quite an undertaking, but time and patience are equal to anything.

The routine of the garden for this spring was very simple. The planting was all done, and, as the strawberries occupied every available foot of ground, the young folks were relieved from all further trouble, and the actual amount of work to be done was extremely small. The mulch kept down the weeds, and beyond this, till the time 
came for gathering the new crop, there was little else to be done.

As the blossom buds pushed out and lay thick and suggestive among the plants, the Wellson spirits rose. Even the toiler of the family was cheered at the sight of the expected crop, and still more at the bright and happy looks of the young people. The out-of-door life, and the interest excited, by having something to show for the labor of his hands, stirred to more active and uproariously jolly life, the sturdy young John, Jr. As for Kate, she was just merging into young womanhood, and perhaps her spirits were toned down slightly, yet the brilliant color and clear, healthy glow on her face showed that the outof-door life was of benefit. Yes, - that's it: Work, outof-doors; something to do in the real tangible world of nature, - that is the cure for many an ail and ill both .mental and bodily. Her loveliness, Mary, seemed to think so. Her color returned, and though there was sometimes a shade of sadness in her eyes, she was generally her old serene and delightful self.

So much for the strawberry garden as a medical prescription. The family doctor nodded his head, saying with a smile, "Nothing like a little out-of-door employment, Mrs. Wellson. Nothing like healthful work." $\quad$ [See Appendix C.] 


\section{CHAPTER XIII.}

THE STRAWBERRY SHOW AND WHAT CAME OF IT.

The Wellson kitchen. Mrs. Wellson, Johnny, and Mary, busily sorting and arranging heaps of ripe strawberries. The table is piled high with fruit, and a huge hamper stands loaded by the door. All is activity and bustle. A most tremendous crop of fruit, and the entire village wild to purchase it. Out in the garden two young girls, hired by the day, are picking as fast as their fingers can fly. In the village street are four private carriages drawn up in line, and just outside the back door, in the yard, is a broad table, made of boards supported on barrels. A white cloth is spread over it, and everything is as nice as a new pin. The blooming Kate, activity itself, is waiting upon half-a-dozen impatient people, who present baskets and tin kettles to be filled with the luscious fruit. Kate measures it out, a piled-up quart, at a time, and gives it to the various purchasers. Soon all the fruit on the table is gone and she runs to the house for more. Bursting into the room, she extends her hands stuffed with scrip. "Give me your money-box. Sold out. Some more berries, Johnny. They are going like hot cakes." 
"Hooray, Kate! Give it to" em! More berries. Fly round, Mary! There's lots of folks coming."

More people crowded into the little yard, and Kate grasped the huge hamper and went forth to meet the new demand. As she placed her load on the little counter, she glanced at the people. There were two elderly gentlemen, a young girl, and a young gentleman with only one arm. Kate did not recognize him at first, but as he drew near she saw who it was, and dropped her tin measure in a little fright.

One of the elderly gentlemen offered a basket.

"Give me four quarts, miss.".

Kate, with trembling fingers, and her thoughts in a perfect whirl, mechanically handed out two quarts, and said briefly:-

"Sixty cents, sir. Thirty cents a quart."

"I said four quarts, if you please."

"Oh! excuse me. I didn't think."

While she measured out the rest, the two gentlemen fell to talking:-

"Wellson hit the nail on the head this time."

"Yes. They are the best berries I ever bought. I'm glad enough to pay the price. They are sure to be fresh and clean."

"That is true, and our young lady gives us good measure. The idea of selling their surplus berries in this way 
is certainly a new one. I suppose Wellson makes a good thing of it. How much do you sell in a day, miss?"

"About twenty-five dollars' worth. We could do better if we only had more land."

"Don't think it, my dear. That never follows. It is the high culture of the small farm that is best. Had you more land, you would not cultivate it so thoroughly. Here is your money."

Kate took the change, and then turned to her next customer. While she was serving him, the young gentleman stood aloof, looking gravely on.

"What folly in me!" said he to himself. "Why should not they, or any one, do this? I fancy that nonsense is well knocked out of me, now that it is too late. My insane and foolish pride has done, it all, and - well - I might try, at any rate. I'll do it."

The other people were now served, and went away. Kate was in a perfect tremor of excitement. She managed to stammer out:-

"Will you have any fruit, sir?"

"Yes - no - why, yes, - I will, only I have nothing to take it in."

"Let me get you a basket," said Kate. Away she flew towards the house. As she pushed into the kitchen she cried, "O Mary! Mary!"

She paused abruptly. Mary was not there. 
"Mary has gone to dress for the Strawberry Show. What do you want?"

"Nothing, - only a basket."

When she returned, she was surprised to find her father talking pleasantly with the joung man.

"When did you return?"

"Only this morning."

" $\mathrm{Ah}$ ! your departure was sudden, and your return a surprise, - and a pleasure, I'm sure. We shall be glad to have you call."

The young man looked as if he would be glad too, very.

"Here's Kate," said her father, laying his hand on her fly-away hair, and smiling at her rosy face and bright eyes. "She is our gardener and saleswoman. Our wonderful success in our little garden is mainly owing to her efforts. She and Johnny have run the whole establishment."

"Say Mary, too, father; she helped us whenever we had a hard place. Besides, it was her idea that we sell the berries in - "

Suddenly she thought of something, and blushed scarlet. Her father looked amused, and the young man studied his boots intently.

Just at this point Johnny appeared with another hamper of fruit. More people crowded into the yard, and in the new demand Kate forgot both her father and the young man.

Five minutes after saw the berries all gone, and more 
customers waiting to be served. Kate turned the basket upside down and said :-

"Sold out. All gone. More to-morrow." Still the car- " riages drew up at the gate, and the people streamed into the yard, asking for those extra fine, extra large, and every way extra, Wellson strawberries. There were no such berries in the market, and they were certainly worth double the price asked.

But it could not be helped.

"We have sold out," said Kate. "Glad to take your orders for to-morrow."

Many left their orders, and at last they all departed. Kate, singing merrily to herself, began to fold up the cloth on her counter. Looking up, she beheld the young man writing a little note, with his left hand upon his knee. Soon it was done, and, folding the paper as best he could, he gave it to Kate, saying:-

"Would you be so kind as to hand that to your sister, Miss Wellson?"

"Oh, with pleasure," said Kate, blushing, and beaming radiantly upon him.

She took the note and thrust it into her pocket. Just then more impatient people came for the wonderful Wellson strawberries.

"All gone," said Kate.

The people grumbled mildly, and then departed. Look- 
ing about for the young man, she found that he had disappeared.

Kate seized her roll of cloth, made a grand flourish with it in the air, and said, "Hooray for the strawberry-bed! as Johnny says. It brings the money, - and - Oh! I am so glad. Where can that blessed Mary be? I must find her this minute, and give her this precious note. I suppose she has gone to the Strawberry Show. I'll go too."

The Wellson dining-room. Father and Mother Wellson studying a small account-book. No sorrowful looks now. The balance is on the other side; the result - happiness.

"And it is our children who have done this."

"Yes, the best of the whole affair is in our children. The money is well; but it is not all. Oh, not all. Think of our splendid boy, and Kate, too, the healthy and happy! And Mary. Happiness has come to her, too, I hope."

"What do you mean, wife?"

"Are you so blind? Have you not seen it?"

"Really, no. It must be that I was much taken with my glorious Kate. Isn't she a treasure?"

"Not one, my love, all are treasures; and to think how what seemed a sorrow has turned to joy. Oh, that every one would lead their children to see the blessedness of honest work! But come, it is time to go, if we care to see the prizes given out."

It was in the Town Hall. The whole village and his wife were in their Sunday best, and on its way to the Show. 
The local Horticultural Society had offered a tempting array of prizes for the best berries, and everybody was eager to see who had won them. Strawberry culture was practised quite generally in the country thereabout. Mary, with her father and mother, had gone before, and Kate, escorted - by her brother, followed after.

When they reached the door, they paused to read a flaming placard announcing the list of prizes.

"Twenty dollars for the best basket of one variety. Ten dollars for the second best, - and, O Kate, they are going to give a silver cup for the three best baskets of any varieties. If we should get that, wouldn't it be fine?"

"Yes," replied Kate, scornfully. "Some little child's plated cup. Who cares for that? I'd rather have the twenty dollars, any day."

"Perhaps we may get it. Who knows? Our baskets were pretty fine, I can tell you. There were not many as good."

With a good deal of excitement, and curious to see how things would turn out, they paid for their tickets and entered the hall. It was very warm and close. The people crowded round, and the village brass played in the most approved manner. Everybody talked as loud as they could, and altogether it was a very great occasion. Johnny pushed through the crowd, and dragged his sister after, as best he might. As for seeing anything, it was next to impossible. 
"Let's get up on the platform, Johnny. We can't see a thing here."

"Come on, then."

Suddenly the brass uproar ceased, and the vocal uproar, finding itself alone, dropped down also.

Then there was a movement among the people, and our young folks found themselves pushed along towards the wall. The people about them were extra tall folks, and they could not see.

"This is not lovely," said Kate. "Let us get up on this seat."

With an effort Johnny climbed upon a settee standing against the wall, and then assisted Kate to mount beside him.

"This is just gay," said Johnny. "We can see everybody."

"Yes, and be seen. It's rather conspicuous. What would mother say, if she were to see us perched up here?"

Johnny would have replied, but just then a big, burly man, with a rough, roaring voice, mounted the platform, and, gazing over the sea of heads, called the company to order.

"They are going to give out the prizes. We shall have a splendid chance to see who gets 'em."

The crowd became reasonably quiet, except around the edges, where certain boys in the veal period, and sundry juvenile couples, would persist in whispering. 
Then the president made the usual horticultural showspeech, which we will not report, as it was just like a dozen others you have no doubt heard or read.

Then came the list of prizes to be awarded by the committee on fruit. The honorable officers on the stage, and the band listened with exemplary patience. Curiously enough, the list began at the little end, and the lucky person was requested to step up and receive from the president the prize. The small prizes were announced first, and.as the list went on, our young people listened, in a flutter of excitement. If their baskets of fruit should draw a prize, how very splendid it would be!

Nearer and nearer to the end came the list. As the five and ten dollar prizes were announced, a breeze of excitement swept over the assembly. Each one, as his name was announced, was congratulated by his neighbors, and a little buzz of talk spread through the company. The president paused The last and highest prizes were reached.

"For the best single basket, twenty dollars. To Master John Wellson, Jr."

Kate gave a little scream, and then put her hand over her mouth. Instantly she dropped from her perch to the floor. She struck her knee on the seat, and the pain was sharp, but that was nothing. Only let her get down out of sight of all these people. How they did stare, to be sure! John, Jr., was bolder; and kept his place in spite of 
the five hundred pair of eyes levelled at him. How quickly everybody found him out!

"Make way for the boy," said a burly man near by.

"Come, sonny. Go get your prize. You won it fairly. I've seen you at work, and you deserve it, because you did not mind the talk they made about you."

Johnny climbed down, and, the crowd making a lane for him, he started to get his prize. Kate mustered courage to follow him. As she went along all sorts of remarks fell on her ear :-

"Good for them! They done it theirselves. So much for not being afraid of work, nor of the mean talk."

When they reached the front of the stage, Kate was surprised to see the faded little Widow Scrabbins and her gossipy friends; Farmer Gooding and his blooming daughters ; a certain one-armed young man; and she even thought she saw her father and mother, both looking very radiant.

The president leaned forward and said to Johnny :-

"Is your name Wellson?"

"Yes, sir. -John Wellson, Jr. I will take the prize."

- Kate pinched his arm, and the president laughed goodnaturedly.

"With pleasure. You have fairly won the prize. Such an industrious worker deserves this, and more."

A new twenty-dollar bill was placed in his hands, and the people crowded round to congratulate him. 
"Let us go home, Kate. Come."

Kate, beaming with happiness, and flushed with success, prepared to follow him. For a moment thoughts of the petty gossips and their doings flashed through her mind.

"Where now are the folks that said such horrid things about us? They'd like the prize themselves, I suppose. But we'll forgive them. I'd forgive anybody, I feel so happy."

Congratulations poured in upon them from every side. All thoughts of ill-will, towards even the Widow Scrabbins, fled before her present joy.

The president called the people to order :-

"Will the audience please gire attention? There is one more prize. For the three best baskets of any kind, - a silver goblet, to Miss Kate Wellson."

Every spark of color left her face. She was panicstricken and wanted to fly, but could not. The crowd pressed closer round her, and a murmur of applause spread through the company.

"Go get it, miss," said some one beside her. "Gro get it."

She tried to run away, and looked to Johnny for assistance. He was gone, - lost in the crowd.

"Walk right up, miss, and take your prize," said several about her.

"Take my arm. Miss Wellson. I will escort you." 
She looked up timidly, and saw beside her a certain young gentleman, with but one arm.

She blushed scarlęt. "Oh ! that note. She had not delivered it yet."

"Thank you, sir," she modestly said, took his proffered arm, and marched up to the platform in the company of the just returned squire's son.

The people made way for them, and the beautiful silver cup was placed in her hands.

"How lovely! Isn't it beautiful? Won't Mary be glad to see it?"

The arm on which she leaned trembled slightly, and her cavalier turned his face away. Full of her wonderful experience, she went on talking gayly.

"Oh, how perfectly splendid! The very thing sister was wanting for a spoon-holder."

The young man looked at her curiously.

"Is your sister going to begin house-keeping?"

"Oh, dear! no. Ah! there she is!"

"Where?" said the young man.

"Just by the door. Oh, she has gone, the little goosie! She has run away. Come, wouldn't you like to help me find her?"

"With pleasure. May I not escort you from the hall?" "Oh, yes, all the way home if you like," said the happy Kate. 'To be escorted through the company by the squire's son, and to allow all to see the prize cup, was certainly the 
happiest event in her life. She was quite upset, and was not sure what she did say.

Her good-nature fairly bubbled oyer, and with hearty gayety she beguiled the way, leading the young man,to happiness - or sorrow - which ?

As they drew near home, Kate suddenly remembered the note in her pocket.

"Oh! what shall I do? I don't know that you will forgive me."

"Why not? What for?"

"The note. You see I have not been able to see her yet; and then there were so many things going on, really, I quite forgot all about it."

"Don't trouble yourself, Miss Wellson. No doubt you would have delivered it if you had seen her. Yet, now I think, you may give it to me, and I'll see her myself."

"Oh, no, I can't really. We - that is, Johnny - lost a note once that some one gave him for Mary, and she was dreadfully sorry about it for a long time."

"Was she, indeed?"

Just at this point they reached the Wellson gate. Kate, all eagerness to show her prize, was on the point of rushing into the house in her usual impetuous manner.

"You will not forget the note," said the young man.

"Oh, no indeed; but aren't you coming in? Mary will be so gla-"

She put her hand over her mouth suddenly, looked hard 
at the silver goblet for a moment, and then with ready wit held open the gate. With a smile she said :-

"Come in."

At this moment the uproarious Johnny appeared, accom- . panied by the man who kept the village hotel.

"Yes, sir," said Johnny, "you may have 'em and welcome. The folks in the hall will give'em to you, if you send the baskets home."

The man took out his purse, and gave Johnny a fivedollar bill, and then went away.

The excitable boy, without noticing the arrival, flung his hat in the air, and cried out, "Three cheers for the strawberry garden!"

"Hooray!" cried Johnny.

"Hurrah!" cried the young man, waving his cap.

"Hurrah, boys!" said Kate, displaying the glittering prize.

Some one in the house, hearing the noise, drew up a curtain and looked out. Johnny caught sight of the goblet, and was transfixed in astonishment. Somebody else saw something, and - four people, "lost in wonder, love, and praise." Tableau.

Two hours later. The twilight was fading, and over the tall house-tops rose the summer moon. Two young people walking down the narrow garden-path among the strawberries. How very slow they did walk, to be sure! They had so much to say to each other. 
"And you will forgive me?"

"O Edward, you know I will. I never doubted you an instant."

"What you say makes me the more sad. I doubted myself. Remember iny mother, and her wretched teachings. She it was, who, hearing the distorted stories of your doings, made me believe it were dishonorable to work with one's hands. In my vanity, I associated debasement and loss of all that is best in a young lady, with the idea of her being at work like a common laborer."

"And you failed to see that -

" "Where love's the cause,

'The meanest work's divine." "

"I did, and cannot cease to blame myself."

She placed her hand on his mouth, and said : -

"It is more blessed to forgive than be forgiven. Now tell me how it happened that you ran away, and never sent me a single line for all those long months, and then let me tell you a fable."

"I was called away to New York, then sailed for South America very suddenly on business. I did write to you, and gave the note to your brother. As for further correspondence, another time I will tell the long and dreary story. The accident which cost me my arm, and the two occasions when I was ill, explain in part. The rest another time. The fable, please." 
"Once upon a time, a man met with some injury, and his neighbors reported that he had been attacked in the woods by twenty black crows and nearly beaten to death by their strong and ragged wings. How the little black spot on his forehead grew to cover his whole face; how he looked as black as a crow; how a crow chased him; how two crows had pursued him; how the two crows became twenty, and how, what was a mere scratch because it was black, grew to this formidable history, would make a queer study for a student of human nature. Such is gossip."

"Wisdom itself. Come, my dear, let us cross the garden wall, and wander together in the open fields for a few moments. The night is fine and the moon is bright."

They wandered - for a lifetime.

Six months later. A very strong fragrance as of tubo roses and orange-blossoms pervades the Wellson mansion.

The horticultural season is over, and Johnny is counting his gains in his own room. Here is the account for the season :-

Received last year,

. $\$ 7910$

Received for 2,082 qts. of strawberries, at 30 cents, . . 62460

" " $400 \mathrm{lbs}$. of grapes, at $10 \mathrm{cents,} \mathrm{.} \mathrm{.} \mathrm{.} 4000$

" " " lot of pears, . . . . . . 1500

" " sale of prize fruit, . . . . . 500

Prize, • • • • • • • • • • 2000

$\$ 78370$ 
Cost of original planting, including labor and plants : -

Labor of man one week, $\$ 1200$; plants, $\$ 3000$; mulch, $\$ 600,4800$ Interest on 30,000 feet of land, at 6 cents a foot, for two years, 10820 Cost of culture and use of fixtures, . . . . . 1290 Cost of vines and culture, . . . . . . 6000 $\$ 22910$

Grand total result,

As the account is finished, Johnny jumps up and cries, "Hooray! Hooray! We have done it this time, sure."

The door opens suddenly, and a vision of feminine loveliness, arrayed in gorgeous apparel, as for some festive occasion, enters.

"Look at that, Kate. Look at that."

Kate took the proffered sheet gingerly in her kid-gloved hands. "Yes, yes, Johnny, I see. It's perfectly splendid, but, oh, dear, aren't you dressed for church yet? The carriages will be here in half an hour."

"I know it. I'll be ready. But just think of the strawberry-garden! Isn't it jolly?"

"Yes, I see; but you must hurry. Indeed, you must. There's mother calling. I must run."

And she ran away, leaving the door open behind her. A delicious odor of mingled flowers, cake and coffee floated into the room.

"Hi!" said the boy, a boy still; "that smells good. What a stunning wedding sister Mary is going to have, to be sure! Now John Wellson, Jr., get into your new coat with tails, and prepare for a very grand occasion." 


\section{A P P E N D X.}

\section{APPÉNDIX A.}

IT may be well to state that the kinds of strawberries used by Mr. Harker were the Brighton Pine and the Lady of the Lake, two varieties originating in his own State, Mass.

They are not offered as the best, but as illustrating the only principle that should guide the grower in selecting the kinds most suitable for him. Grow those kinds known to succeed best in your own neighborhood.

\section{APPENDIX $B$.}

Domestic waste. By this is meant all the liquid refuse of every kind from the house. On the Wellson estate every drop of water from the sink, the bath-room, and water-closet was collected in a large cistern sunk in the ground at a short distance from the house. This mixture was used as described, and proved efficient in keeping the land up to a highly fertile point. The pump was used regularly summer and winter, and no inconvenience resulted to anybody. In winter it ran away under the snow, and, in summer, advantage was taken of a fall of rain, to wash it into the soil.

Very' few people are aware of the great waste in our 
households. Were it all saved, the result in abundant crops would astonish even practical gardeners. This plan is in operation at the Horticultural School with which the writer is connected, though in a somewhat different way; Instead of using the material in a liquid form, absorbents are used, and the result is an abundant supply of fertilizers for garden purposes at a very low cost.

The writer himself uses a chain-pump, as described in this chapter, in the business operations of the gardening firm, to which he belongs, at West Newton, Mass.

\section{APPENDIX $C$.}

The after culture of the strawberry plantation was this : The leaves that lay thickly scattered over the soil decayed, and as soon as the crop was gone they were lightly forked - into the ground. Through the summer and fall frequent stirrings of the ground and the persistent cutting away of all the runners made the most of the work. The rest was merely to keep things clean and nice.

The work for the next season was but a repetition of this, with one exception, - when the crop was picked, the whole affair was ploughed up, and the land given over to some other crop. Whether the land was ever planted with strawberries again is more than can be said, as the writer has not visited the Wellson family since. 


\section{VEGET A B L E S. "GARDEN SASS."}

\section{FARMING BY INCHES; OR, "WITH BRAINS, SIR."}

MR. AND MRS. ROBERT NELLSON'S SUCCESSFUL EXPERIMENT. 



\section{FARMING BY INCHES;}

\section{OR, WITH BRAINS, SIR.}

\section{CHAPTER I.}

THE DREAM REALIZED.

"WeLL, doctor, what is it?"

"Oh, nothing serious as yet. He seems very weak, but I cannot discover symptoms of any definite disease. I think his illness is more the result of overwork than of anything else. $\mathrm{He}$ is asleep now, and had best not be awakened." So saying he opened the front door and departed into the gas-lighted street.

Locking the door, I went upstairs, turned down the gas in my husband's sick room, and, wrapping a shawl about me sat down by the fire in the next room to watch and to think.

My husband, the head book-keeper in a down-town commission-house, had been brought home in a carriage that morning quite ill. He had not been well for some time, but, not thinking it anything serious, had continued his daily labor at his desk. At night he had seemed worse; so I called the doctor. You have just heard what he said as he 
went away a few moments since. We have been married about a year. This house, No. 95 Columbia Avenue, is cur home. We are both orphans, and have no relations of any kind, save an uncle of my husband's living in Arenac, some fifty miles from the city. So far our married life has been very happy. Our income was sufficient to give us a home, comfortable, if not luxurious. But now a cloud had risen. My husband and bread-winner was sick, and that meant poverty. If he could not toil at his desk, our income was at an end, and with all our economy we had laid aside but a trifling sum for such a contingency as had now overtaken us. Should he remain ill for many weeks, our case would be desperate. Slowly turning over these things in my mind, I sat gazing at the fire, and trying to build up in the glowing coals some vision of the future. After a while, weary with watching, I fell asleep in my chair. Suddenly I seemed transported to some distant spot. I thought I was in a quiet room somewhere in the country. The window where I sat looked out upon meadows green, fair with flowers. Graceful vines trailed over the casement and cast a checkered shade on the floor. The sun was shining brightly, and a gentle breeze just stirred the leaves upon the tall trees that grew beside the house. Presently the door opened, and Robert, my husband, entered, and, oh, how changed! He seemed ten years younger. Perfect 
health flushed his cheek and sparkled in his eyes. His voice, usually so weak and thin, greeted me with loud and hearty welcome. Overcome with joy, I went to meet him - and woke up to find the fire out and the cold, gray light of a winter's morning streaming in at the window. Peering out through the frosted panes, I saw a heavily laden horse-car painfully toiling through the snowy street. A few pedestrians, well wrapped up, were hurrying along the sidewalk, trying to keep warm. The sky was the color of lead, and the air was full of falling snow. Altogether, it was a dreary scene. Going to my husband, I found him still asleep. As I stood looking at him, I was struck by the pinched and haggard expression of his face. It was the face of a man starved for the want of fresh air and sunshine. Presently he opened his eyes and smiled on me; but it only made me heart-sick to see it. It was a sad and weary smile.

But why prolong the story? For six long weeks I hardly left him for a moment. The doctor came nearly every day. My husband's employers called several times, offered every kindness, and, in the spirit of true and honorable merchants, continued his salary during his illness. Àt last he was able to sit up, and could even sit by the window for an hour or so, and amuse himself by looking on the busy street. Yet he seemed very weary and listless all the 
time. I tried hard, but failed, to interest him in anything. One day, to entertain him, I told him my dream.

"Yes, Harriet, but it was only a dream. Such a pleasant home is never destined to be ours."

Then he leaned back in his chair, and seemed lost in thought, while I went on with my sewing. In a moment or two a smile flitted over his face, and he stared very hard out of the window as if he saw something vastly amusing in the street. But this did not last long; he soon turned away, and the same old look of weariness returned.

"A penny for your thoughts, my dear," said I. "If they are pleasant ones, give me my share; if they are sad ones, let me divide the burden with you."

"I was thinking of your dream, and wishing we could make it come true. These brick walls and Farwell \& Co.'s sunless cistern of a counting-room are slowly killing me. But it is of no use. I could not earn my salt in the country."

Farther conversation was then silenced by the entrance of the doctor. To tell the truth, I was not glad to see him. His bill was already large enough, and we should have a sorrowful time in paying it off, and to see it increased by another visit was not pleasing. Yet I was mistaken in the man. He had come to do us a real kindness. Going up to Robert, he took his hand and said, "This will be my last 
visit at present, Mr. Nelson. In a few days, I think you may venture out for a walk in the middle of the day. You must not think of returning to your desk for some time. To tell the truth, I have come this afternoon to say that in my opinion you had better never return to your countingroom at all. Nature has now given you one fair warning. This illness, if you read it rightly, is sent to inform you that she objects to your occupation. You must heed her, and give it up."

"Well, doctor, if I did not know you to be a man of sense and education, I should say you were getting quite wild. The thing is impossible. What can I do, if I leave the office?"

"That is more than I know; but I do know that you must throw up your business, or shorten your life by about twenty years. Your desk will as surely kill you as any other slow poison."

"You may be right," said my husband, after a pause. "I have even thought of this myself at times. But what can I do? Where and how can we live?"

"6. How you can live is more than I can tell. Where - is plain enough. You must live out of town - or die. 'Come, take my advice, sell out and move into the country."

"A very pretty idea, doctor; but in the country I should quietly starve. I may as well stagger along as I am for a 
few years, as to go from the city and die of poverty in a few weeks."

"Nonsense! man; you are sick, and hardly know what you are saying. The idea of a man of your education wanting for support anywhere! Take my advice, seek some out-of-door employment, - farming, surveying, - anything that will keep you out under the open sky and in the fresh air."

To this there was no reply save a gloomy shake of the head. Then the doctor bade us good-day. As I opened the door to let him out, he said to me, "Mrs. Nelson, there is but one thing to be done. Take your husband away from the city, and keep him away; that is, if you wish to see him live."

Next morning the letter-carrier brought a black-bordered letter for my husband. I gave it to him, and he broke the seal and read it. It did not seem to interest him much, for he merely said, "Old Uncle Jacob is dead. Poor man! his was a dull and lonely life up there at Arenac. It must be almost a relief to be taken away, and to join his long-dead wife and children." Then he continued his reading. Soon he came to something interesting, for he brightened up, and with a smile passed the letter to me.

It was as follows :- 
"ARENAC, March 3, 186-.

"Mr. Robert Nelson.

"Dear Sir: It is our painful duty to inform you that your uncle, Jacob Nelson, died at his residence a few days since, and was buried yesterday. We would have informed you of this before, but we were ignorant of the fact that he had any living relations. We were only apprised of it this morning by finding his will among his papers. By the said will you are made his sole heir. His property consists of the small house in which he lived, a parcel of land, and a small sum of money in our Savings Bank. The house is unoccupied at present, and awaits your disposal. The estate could be sold readily, if you have no other use for it. An early visit from you is desirable.

"Your obedient servants,

"CRESSWELL \& JOHNSON,

"Attorneys and Solicitors."

"When shall you go?" said I.

"Go where?"

"Why, to Arenac, to see our little estate!"

"No, I'll not go at all. I will write to these people, and have them sell the place and remit the money. I cannot afford the time or money to travel so far."

"Now, Robert, I object. Let us both go there. It will do us good to have a short trip into the country. The 
money will be well spent; besides, it will be but taking a* dose of the doctor's last prescription."

At nine o'clock on the following Monday morning we were seated in the cars, ready to start for Arenac. There were but few seats occupied, and we arranged our wraps and shawls so as to have as comfortable a time as possible. Just as we had got nicely fixed, two stout countrymen came and sat down in the next seat behind us. They both took out papers and fell to reading. Soon we started. For the first half-hour we were speeding through the suburbs of the city. Then the houses dwindled away, and the open country with the fields and woods slid like a panorama past the windows. At first Robert discovered but little of interest outside of the car; but the sight of the brown fields and bare woods seemed to bring back memories of his boyhood, and he brightened up and manifested more signs of returning health than I had dared to hope for. After a while he became tired of gazing at the scenery, leaned back, and closed his eyes as if to rest, leaving me to my own devices. As for me I was only too happy to see him, as I fondly imagined, already getting better. Just then the two men behind us finished their reading and began to talk. They had evidently never learned the "car-whisper," and I could hear every word.

"How's business, Jack?" 
"Good enough. We can sell all we can get. The trouble is to get enough to sell."

"What you selling, mostly?"

"Meat and sass. It is mighty hard work to get good sass up at Arenac. The farmers won't grow it, and we have to send to the city for all our stuff. Besides, the jobbers ask so much that our people won't pay us enough to make it an object."

"I found the same trouble at my place. They all want green sass in the spring, but don't want to pay such high prices. However, they will have it any way, and once a week I get up a car-load from town. I don't make anything on it. It is pretty well spoiled by the time I get it. I have asked Farmer Brown to raise me some; but he and all the rest do as their fathers did, and run in the same old rut. Any one who would raise sass for us would make a small fortune in time."

We reached our destination at noon, and went at once to the hotel. After dinner and a short rest, we started out to inspect the place. We found Arenac to be a manufacturing town on the banks of the Hoosensacken. The factories were all on the line of the river, and faced the single street that extended through the town. On the opposite side of the way were the various stores that supplied the material wants of the inhabitants. As we 
passed along the sidewalk, I saw one of the men who sat near us in the cars. He was standing at the door of the market, and seemed quite at home there. We found three hotels, and four churches, and these, together with the factories and dwelling-houses, made up a thriving New England village. A single covered bridge spanned the river near the railroad that crept along under the riverbank. Just over the river a lofty, wooded hill rose like a great wall, and lifted its rocky crags high over all.

The next morning we obtained the key, and started to walk out and see Uncle Jacob's little piece of property. We soon left the houses behind, and came to the open fields. The day was fair, and the March sun was shining brightly. The scenery, though brown and bare, was lovely. The walking was good, - and to walk or even live was a pleasure on such a day, - while the pure and bracing air inspired us with a sense of freedom and space to move about in, that was a delight only city-bred people like ourselves could appreciate. After passing several farms, we came to our own little place, as we had already learned to call it, though we never intended to occupy it. The house was quite small, - merely a one-story cottage, of five rooms. Behind the house was a small barn. The parcel of land we found to consist of a ploughed field, having thick woods on three sides, but open on the street, 
or south side. On entering the house we found it neatly but plainly furnished. Uncle Jacob had evidently been a man of refinement, if not of wealth. After inspecting everything, we sat down by the warm, sunny window to rest and admire the charming view. On the opposite side of the road, wide-spreading fields extended toward the village, whose tall spires and chimneys peered over the low hill beyond the fields. Beyond the village, Mount Arenac. To the right we could see far down the Hoosensacken valley, till the hills on either side were lost in the blue distance. To the left, thick woods.

"Charming view, - is it not?"

"Yes; but it must be very lonely here."

"That is true," said I; "yet I should enjoy living here during the summer months."

"And I, too. It would do me a world of good to spend a short time in this breezy mountain region."

"Why not do so? Why not shut up our city house, take a vacation, and stay here until the middle of April? By that time you will be so much better you can return to your desk with renewed strength and health. We can manage to picnic in this box of a house for a few weeks very comfortably. Then, too, we shall escape the raw east winds of the coast. It will do us both good, I am sure. Besides, it will be cheaper living here than at 
home, and the expense is something we have to consider just now."

Two days after this, our trunks were established for bureaus in our new residence, and my dream in a measure came true. 


\section{CHAPTER II.}

\section{FARMING ON PAPER.}

As we intended to return in a short time we brought but little from the city, but used instead the things which we found in the house. Our time we passed in most delightful idleness. We had come for rest, and to recruit our health and strength ; therefore we took things as easily as possible. We had but two meals a day, to save trouble. Most of the time we were out walking, or reading when the roads were bad. We slept a good deal, and did nothing a good deal more. About the twentieth of the month we began to recover our old-time health and spirits; for I found when the excitement of my husband's sickness was over, that I, too, was far from well. It was then I began to wish we could stay here all the time. Turning this over in my mind, I wondered what we could do for a support if we were to remain. We could not live in idleness, that was certain. Ait breakfast one morning, I opened the matter by saying:-

"What is sass, Robert?"

"Garden sauce, I suppose, - lettuce, beans, etc."

"Do you remember our first ride up to this place?" "Yes; what of it?" 
"Did you hear the conversation between the two men who sat behind us in the cars? Your eyes were closed at the time ; perhaps you were slecping."

"No, I was only dozing and heard every word. I have several times thought of what they said, and wondered why no one tried to supply their wants. I am almost tempted to do something of the kind myself; but I suppose we have not land enough."

"O Robert! do try it. We have a three-acre field. Is that not enough to experiment upon? Do try, please, for six months. Send word to Farwell \& Co. that you have decided to give up your place; doubtless you can command another in the fall. It is of no consequence if we do not make anything by the operation. If we pay our way it will be enough. We can sell out in October, and return to the city with your health established for life."

"The idea, Harriet! The idea of our turning' 'sassfarmers.' What could you do-a woman, or I - a bookkeeper?"

"Do? Why, you can do anything, if you only try. The doctor said a man of your talents would prosper anywhere. As for me, I could help in many ways besides keeping the house, picking peas, washing lettuce, or other light work."

"What a woman you are, Harriet! With such a wife, a man would succeel in anything. I shall, I am sure. By 
the way, see what I found at one of the hotels yesterday."

So saying, he drew forth a small paper-covered book, - "Washburn's Amateur Cultivator's Guide to the Flower and Kitchen Garden."

"Just what we want," said I. "Fortune favors us slightly, Robert. Come, let us set up for 'sass-farmers' for a summer."

"Agreed! We will farm for a living for six months. Then we will cast our shells, and come out in our original characters as city-folks."

So far I have told my story as if I were the ruling spirit in the house. My husband's illness threw nearly all the responsibility of our action on me. As his health returned, I gladly gave up the reins, and henceforth this will be more the record of his doings than of mine, or, better, our doings, for in the new farming enterprise we had an equal share. I tried to carry out to the best of my ability the old-fashioned idea of a woman's being a helpmeet to her husband. At first I imagined in my ignorance that I could aid him directly about our little farm; but I soon found that there was an immense deal to be done aside from mere field-work. My share of the duties ultimately became that of house-keeper and accountant. In this I was fully employed. The house-keeping part was easy enough, but keeping accurate accounts of 
our sales and expenditures proved to be no small undertaking. After we were well under way hardly a day passed without its moneyed transaction to be attended to in detail. One day there would be a quantity of strawberries to be sent off, the bills made out, and the boxes accounted for ; another day a wagon load of vegetables had to be counted, despatched, and properly accounted for on the return of the empty wagon. Perhaps you wonder why my husband did not see to this himself, he being a skilled accountant. It is true he could have done so; but every hour spent on work I could do as well was an hour lost on work I could not do at all.

Having fully made up our minds to try our hands at the business of farming, we resolved that all things should be conducted in the most systematic order. We would bring our methodical and mercantile ways of doing things into a business notoriously loose and inaccurate in its operations. Manifestly the first thing to be done was to draw up on paper some sort of a plan of what we proposed to do, and then endeavor to carry it out as nearly as may be.

After breakfast Robert walked to the village and procured the deed of our estate. Therein we found ourselves possessors of a certain parcel of land, bounded on the east by a line commencing on the county road at a stone post next adjoining the estate of Widow Comfort Jones, and running 
northerly three hundred and sixty-three feet, to the estate of Justin Stamford; thence westerly three hundred and forty-five feet, to the estate of Isaac Kempenfielder; thence southerly three hundred and sixty-three feet, to the county-road; thence easterly along said road to the first-named point, - the total area being one hundred and thirty-two thousand square feet, a little more than three acres. From this must, be taken the land occupied by the buildings and the narrow strip of woods on the north and west sides. The woods on the east belonged to Mrs. Jones, "Widow Comfort," as she was called. After studying this over we walked out to inspect. It seemed very small on paper; but when we had walked over the frozen ground all around the bounds, we came to the conclusion that our little farm was quite an extensive affair when measured by feet and inches. At any rate, to go all round it was something of a walk. Little as we knew about such things we could not fail to see that, for our purposes, no place could be more favorably located. It was open to the sun all day, while the woods formed a shelter from the most troublesome winds. When we returned from our walk Robert got out writing materials, and, drawing a table up to the window, began to write, while I took my sewing and sat by his side, where I could look out far down the river-valley, and watch the shadows chasing each other over the distant hills. Presently Robert turned to me and said : - 
"See, Harriet, here is a list of books on the subject of farming. I made it up from the last page of Washburn \& Co.'s catalogue. I am going to the city this afternoon, and shall be gone two days. I shall get these books, and send them to you by mail to-night. While I am gone you can amuse yourself by looking them over, and finding out what there is in them that will be of use to us. We must follow the example of the students, and 'cram for a profession."

"Books, - I was thinking of them," said I; "but what is going to detain you in town so long?"

"Why, you see, if we really intend to turn farmers, the sooner we begin the better, and the sooner we cut all connection with the city the quicker we can commence. Here is a list of what furniture we shall need while here; the rest I propose to sell. I shall then pay all our bills, give up our house on Columbia Avenue, and dissolve my connection with Farwell \& Co. Do you approve?"

" Yes, I like most of it. I approve of all your plans save the idea of leaving me here alone while you are gone. Why cannot I accompany you?"

"There is no reason why you cannot. But $I$ thought to save you all trouble, and the pain of parting from our first home, besides the fatigue of the journey."

"I can bear the fatigue as well as you; and what if you should be taken ill, and I not near you? You are not yet a 
giant, sir, if you have lived in the country ten whole days."

At six o'clock that evening we were set down in the city. The street lamps were lighted, and as we went up town in a crowded horse-car, we could not fail to notice the difference between the sunny, quiet place we had left, and the dark, narrow, and noisy streets that hitherto we had thought perfection in their way.

The two following days were busy ones indeed. Finally, everything was accomplished, and we took our final departure from the city, bidding farewell, not without a pang, to our city friends and neighbors. They all thought our move a good one as a sanitary measure, but intellectually and socially-doubtful ; financially - very doubtful. How far they were right in this, my story must unfold. That evening we lighted our new centre-table lamp, and sat down by ourselves in our own house, with thankful, hopeful hearts, and at peace with all the world. Every bill had been paid. We were under our own roof-tree, humble as it was, and about to embark upon a new enterprise, in which we could both have an equal share, and be to each other true helpers.

"Now, Harriet, let us draw up some sort of a plan of what we intend to do this summer. The first thing to be considered is finance. We have a house to live in, rent 
free. This furniture, together with that which is on the way to us, is sufficient for the summer. Our trunks contain enough for all our wants as far as clothing is concerned. The question. now is, how much money must we have to support ourselves from now till the first of October? How much will it cost per month?"

"About seventy dollars," said I. "But shall we not receive a large part of our support from the farm? Will not the land contribute to our table?"

"Doubtless ; but let us ' err on the safe side,' and go on the supposition that our farm is not going to pay anything. Then if it does not we shall not be disappointed, nor shall we suffer for want of a support. Seventy dollars a month for six months would amount to four hundred and twenty dollars. I propose to have this sum laid one side for this purpose. By so doing we can return to the city in the fall clear of debt, even though our farming speculation should prove a total failure. If the land does contribute to our dining-table, we will credit the farm with the value of the things so used."

"Why, Robert, you are going into farming like a banker. Do you propose to have a counting-room attached to the place, and to have huge ledgers wherein are entered every little item of receipt and expenditure, after the manner of Farwell \& Co.?” 
" Not exactly; but I do propose to apply mercantile precision to the pursuit of farming. See what a help it will be to us. If we make anything out of it, our books will show how to do it again; if we lose money, they will show us wherein we failed."

"I admit the advantage of all this; but will not the keeping of these accounts require a great deal of time-and labor?"

"In the aggregate it will. Taking it up every day, and squaring the accounts each night, will reduce it to a very trifling affair. According to Uncle Jacob's will we have in the Arenac Savings Bank the sum of seven hundred and fifty dollars. The sale of our things in town, after paying our bills, produced two hundred dollars. Our own savings added to this make our available cash capital up to eleven hundred dollars. Taking from this, four hundred and twenty dollars for our support, we shall have remaining six hundred and eighty dollars for a working capital. Now, what shall we do with it in order to get the largest possible return? Let us consult our first agricultural friend, Washburn. Let us open the book at random, and see what we find."

So saying, Robert opened the book hap-hazard, and said, " Lettuce."

"Just the thing," said I. "Lettuce is classed as "sass,' 
and doubtless will sell well. Shall we put that down for one of our crops?"

"Yes; and having decided to try lettuce we must read up on the subject. Washburn says of it:-

" ' 'The lettuce is generally divided into two classes, namely, cabbage lettuces and cos lettuces. The cabbage have round heads and broad-spreading leaves; the cos varieties have long heads and upright, oblong leaves.

" 'Culture. - A very rich soil is necessary to produce fine head lettuce. Its crisp and tender quality depends very much on a luxuriant and vigorous growth. The earliest sowing may be made in February or March, under glass with slight heat. Keep the plants thin, and admit plenty of air to the frame every fine day. For later supplies, sow in the open ground as soon as the season will permit; transplant, or thin out the plants gradually to a foot apart, and keep well cultivated. The cos lettuces are excellent, if grown early in the spring, but run to seed quickly in hot weather. The large cabbage kinds are best, and most suitable for summer crops.

" "Early-curled Silesia. - Standard sort; very early; the best for forcing and the first spring sowing; makes a loose head; tender, and of excellent flavor.

" “ Early Tennisball.- One of the oldest and most esteemed of the cabbage lettuce. The shed is below medium size; 
dark-green ; very solid if grown in cool weather; one of the earliest and best.'

"And so on, for twenty or more sorts. All this is doubtless very fine, but I doubt if either you or I can understand it all. Wonder what a frame is?"

"I'm sure I don't know. The only frame I ever saw was a bonnet-frame."

Robert suddenly got up and went to the next room. If I had not known him well, I should have imagined he was offended at my levity. In a moment he returned, bringing two large books, which he laid on the table, saying : -

"I bought these yesterday. They cost a good deal, but as tools in our business they will prove invaluable. 'The American Gardener's Calendar,' by Bernard McMahon, and 'The Field and Garden Vegetables of America', by Fearing Burr, Jr. You take one; I'll take the other, and we will read up on lettuce."

For the next half hour nothing was heard in the room save the slow turning of the leaves. Suddenly Robert shut his book with a slam, gave a low whistle, and said :-

"Goodness! What a tremendous thing lettuce is! I have read twenty-six pages on the subject, and am almost in a muddle over it."

"And my author refers to it on thirteen different pages. How shall we ever master the subject?" 
"By perseverance and common sense. I am going to order some seed of Washburn this very night." Then he began to write a letter. While writing he wert on talking. - "As far as I can understand the matter, lettuce seems to be something that can be forced; by that I suppose they mean it can be forced, or compelled, to grow in advance of the regular season by artificial means, such as shelter, etc. I cannot now tell how this is accomplished, but I have no doubt we can invent some method if we put our minds to it At any rate we will try."

The next morning the remainder of our furniture arrived from the city, and nearly the whole day was taken up in setting our new home in order. At nightfall we again sat down to our reading. To tell the truth, we were both fascinated with the books. Though we could not understand all they had to say, yet we found it a novel and pleasing sensation to read and talk about the real, tangible things of which they treated. We discussed lettuce far into the night.

I was awakened early the next morning by a great pounding in our barn. Hastily dressing, I went down to see what was going on. I found my husband had turned carpenter, and was busy with saw, hammer, and boards, making a huge box.

"What are you making, Robert?"

"A hot-bed frame. I made a lucky find this morning. In the barn chamber I discovered three sashes. I knew 
what they were at once, and am going to make a frame to sow our lettuce-seed in."

"What a man you are, Robert! Where did you learn to be a carpenter, and who told you how to make a frame?" "Taught myself- 'Washburn." Then with a few finishing raps with the hammer, he stopped and said, "Come, let us have breakfast. I am as hungry as several bears."

"I am glad of it. It is a good sign, and shows that the doctor's prescription is beginning to work."

As we entered the house I glanced at the clock. "See, Robert," said I, " it is not yet six, and here we both are ready for breakfast. Such a wonderful thing never happened before."

After breakfast my husband took his hat and coat, and bade me good-morning, saying, "I am going to the village to procure some tools."

In about an hour I was startled by the sound of wheels in our yard. Looking out of the window I discovered Robert seated in an old hay-cart, and by his side a tall, elderly man, with iron-gray hair, blue eyes, and a face expressive of good-nature and good sense. As the team drew up at the door, I went out to meet them.

" $\mathrm{My}$ wife, Mr. Kempenfielder. Harriet, this is one of our near neighbors. I met him at the market, and he very kindly brought me and my luggage home in his hay-cart." 
"Glad to see you, ma'am," said Mr. Kempenfielder, advancing and offering his huge, bony hand. I almost laughed when I took it, for I could not grasp such a digital immensity. He shook my hand, and at once I felt a new sensation. It was not like any in my experience. It was a hand-grasp expressive of honest, hearty, good-natured welcome. Not a "society" hand-shake.

"Glad to see you, ma'am. You're welcome to Arenac, I'm sure. Mary - she's my wife - was a-saying the other day she kinder wished some one would locate here. Old Jacob, he that lived here before, was a quiet man, and wan't very neighborly. He's your uncle maybe. Yes, I thought he was. Well, I'm glad you have come. Come over and see us when you get fixed. My folks will be mighty glad to see you. Hello! there, let me help you;" and away he went towards the hay-cart from which Robert was trying to lift a large sack full of potatoes.

"You aint very strong, are you? You look kinder peaked any way. Guess country living will build you up, soon."

So saying, he took the sack from the team easily enough. I could not fail to notice the man's great strength and Robert's weakness. Yet it did not disturb me. One was a farmer, the other a broken-down book-keeper. Which is the better man in other respects remains to 
be seen. Depositing the bag of potatoes on the ground, he then took several garden tools, rakes, shovels, etc., from the cart, and carefully placed them on the doorstep.

"Nice tools, those. Looks as if you meant to garden some."

"Just what we propose to do," said Robert. "We intend to run this small farm this summer."

"Do you though? Well, you are plucky. It's more'n I'd do, and I have farmed it for nigh on to forty years. You couldn't raise wheat enough on that to keep a man busy."

"We don't propose to raise wheat at all."

"Don't you though? Corn, per'aps?"

"No, we shall not attempt any heavy crops."

"What will you raise, - pigs?"

"We hardly know as yet, - not pigs, certainly. We may try lettuce."

"Lettuce! Raise lettuce! Well, I wish you joy in your undertaking."

So saying, he began to clĥmb into his hay-cart. As he started off, he said he was glad to have us for neighbors, but guessed we had a tough road before us.

" Encouraging, - is it not?" said I, rather soberly. "Yes - very - " said Robert, slowly; "but then if we 
change our plans every time any one frowns upon them, we shall not get along very fast."

By noon that day Robert had placed his new hot-bed frame in a sheltered spot on the sunny side of the barn, and had placed the three glass sashes over it. As I went out to call him to dinner, I glanced into the frame, and found it nearly full of broken lumps of frozen soil. The sun shining through the glass was rapidly thawing and crumbling them to pieces.

"What are you trying to do, Robert?"

"Trying to thaw out a part of our farm. I placed those bits of frozen soil under the glass, and guessed they would soon melt. I have guessed right, it seems. By tomolrow I think we shall have some nice dry soil to sow our seeds in. But come, let us dine. After that we will go at our books again, and see if we can find out how many lettuce-plants we can raise. From all I gathered in the village this morning, I guess we can sell all we can produce."

This excited my curiosity, and as soon as we were fairly seated at the table, I asked for further information. "The story is just this. I asked the man at the market if he ever bought lettuce in the spring. Yes, he did, large quantities. He could sell more if he was not obliged to transport it so far. This was too indefinite for me, 
so I asked what he meant by large quantities. 'Many dozens a day,' said he, and then he repeated his remark about the difficulty of obtaining it preventing still larger sales. As he seemed busy, I did not trouble him with further questions. Now, Harriet, let us rake up the little we do know about lettuce, and see what we can figure out of it. Do you remember what we used to pay for lettuce last spring?"

"About eight or ten cents."

"Well, if we paid, as consumers, eight cents, the provision store must have taken three cents for their profit, and the down-town 'Jobber' got three or more cents for his share, so that the grower only received about two cents per head. That seems a very small price; but let us reckon up what the grower could do with it as a crop."

Here my husband stopped suddenly, took out pencil and paper, and became deeply absorbed in some calculations. In a moment or so he looked up and said, "According to the books, lettuce must be planted one foot apart each way. Now, if I am not mistaken, one acre filled with plants one foot apart would contain forty-three thousand five hundred and sixty plants."

"Forty-three thousand plants? Goodness, Robert! How could we ever take care of such an immense number?" Paying no attention to my remark he went on: "Forty- 
- three thousand five hundred and sixty plants, at one cent each, would amount to four hundred and thirty-five dollars and sixty cents." Here he stopped abruptly, and began studying his figures again. As for me, I found something very interesting at the bottom of my tumbler.

"How much did you say it would cost us to live this summer, Harriet?"

"Four hundred and twenty dollars."

"Good. If we can raise an acre or more of lettuce, the question of our support for the next six months is nearly settled."

"Yes, if we can; but you must remember, so far we have been farming only on paper." 


\section{CHAPTER III.}

THE BEST FERTILIZER - BRATNS.

AfTER dinner Robert went out to look at his new frames, while I began to clear away the table. Before I had finished, he returned, bringing in a large sheet of rusty iron, on which was a pile of wet soil. This he gravely placed on the kitchen stove.

"What are you about, Robert?"

"About to apply caloric to a piece of our farm. The soil in the frames has melted, but is still too cold and wet, I fancy, to plant seeds in. I found this bit of Russia iron, and I am going to bake some of the soil on it until it is fit for use."

"Shall we have baked-farm for supper?" asked I, demurely.

"Yes, in time, - that is, we may have the final result of the baking for dinner or supper."

"But you have not soil enough there to fill a tenth part of the frames."

"I know it, my dear. I have a better idea than that. Wait a bit."

Só saying, he went out leaving the pan of damp soil 
on the stove. Presently, he returned, bringing an old raisin-box, some strawberry-boxes, and two or three cracked flower-pots. These he put down near the stove, and getting a seat and a book, drew himself close to the fire and began to read. The sight to me was simply funny.

"A pretty farmer you make, Robert! Toasting your toes and your farm there by the fire."

He never answered a word.

Looking out of the window soon after, I observed a huge four-horse wagon turning into our yard.

"Why, Robert, what is all this? What are these people bringing in here?"

"Manure, I suppose. I bought a large lot this morning."

Whereupon he took his hat and went out. In about half an hour I heard the empty wagon drive away, and my husband returned to his reading. The pile of soil had by this time begun to throw off a cloud of steam, and, drying rapidly, changed color from a disagreeable black to a rich, deep brown. Robert then took the boxes and pots and filled them all full from the heap of baked soil. This done, he placed them on the floor behind the stove and out of harm's way. Taking from his pocket a small package marked, "Seeds only," that 
had evidently come through the post-office, and opening it, he took out a quantity of small white seeds and carefully sprinkled them over the surface of the warm soil in the boxes and pots, and finished all by covering them carefully with more soil from the heap on the stove. Then throwing old newspapers over it, he stood contemplating his work. Suddenly, however, he started as if he had forgotten something.

"Oh! we must water them; but how shall we do it?" "Take them to the sink and shake a wet brush over them," said I.

"A good idea, Harriet, seeing we have no watering-pot." .

In a few moments this was done, and the pots and boxes were replaced on the floor with the papers over them.

The next day was Sunday. At the ringing of the second bell we stepped from our door into the warm and cheerful sunshine to walk to the village, proposing to attend one of its churches. We found the road filled with people, some walking and some riding, and all wending their way toward the village. Being city people, we walked rapidly at our usual sidewalk pace, and passed every one on the road. Soon we overtook a well-dressed lady walking soberly along by herself. As we came up with her, we ventured to speak to her.

"Can you tell us, madam, which is the Unitarian Church?" 
"I can. It is the brown one with the tall steeple. I am going there myself, and will show you the way."

Thereupon we slackened our pace to keep in her company.

"It is a fine day, is it not?"

"Yes, the Lord adorns and gladdens his temple to-day. He delights to make it beautiful; but then, creation, his house, is always lovely. How fine the old mountain looks to-day, such charming light and shade!"

Not quite knowing what to make of this, I merely said, "Yes."

"Do you not admire the true and beautiful in nature?" continued our companion, turning upon us a face full of intelligence, serenity, and refinement.

. "Yes," said my husband; "we do indeed. How can we help it with so much beauty spread around us this quiet Sabbath day?"

We had now reached the church-door, and our guide, whoever she was, passed in before us. Before she left us, however, she turned to say, "My own pew, unfortunately, is quite full to-day, or I would take you to it. But the sexton will, no doubt, find you seats. There he stands near the side-door. Good-morning."

"What a singular woman, Robert!"

"I hardly think that she belongs hereabouts."

"How so?" 
"They told us, you know, we should find only boors in the country."

"They said so, to be sure; but it strikes me they knew nothing about it."

On our return from church, after service, we again overtook our friend just before reaching our own gate. She bowed and smiled, and we returned the salute as gracefully as we could.

" You must be the young people who have moved into the Nelson house?"

"Yes; we have come to spend the summer here for the benefit of our health."

" You could not do a wiser thing. Free air and sunshine are cheap but wonderful remedies for every ill, mental or bodily."

"Do you live near us, may we inquire?"

" Yes, I am your next neighbor. Comfort,-Comfort Jones is my name."

"I am quite pleased to know it," said my husband, extending his hand. "Let us hope to see more of you, Mrs. Jones."

"Thank you, sir. But you must remember, I am an old and very quiet person. I do not venture out much, and am simple and plain in all my ways; not in the least like the gay people you have left in the city." 
"Quiet simplicity is what we desire, madam. My wife and I know how to appreciate it, I assure you."

"Indeed we do," said I. " "None are more simple in their tastes than we."

In truth, this sweet-faced, self-possessed old lady quite charmed me.

"I hope we shall see more of you, Mrs. Jones."

"You shall ;" and she bade us good-morning and disappeared in the woods.

We had a very early breakfast the next morning, as Robert said he had a great deal of work on hand. Breakfast over, he put on stout leather boots and a suit of old clothes, and went out to meet two laboring men who arrived from the village at seven o'clock. I saw no more of him till twelve, when he came in to dinner. We had changed our dinner-time since removing to Arenac, and dined at the unromantic hour of noon. This we found divided our day much more evenly than one or two o'clock. Indeed, one of the first surprises of our country life was the extraordinary length of the days. In town we breakfasted at eight, and had tea at six; but now the daylight seemed to be several hours longer, and an earlier breakfast and later tea required our dinner to come at noon. After dinner Robert brought a large quantity of potatoes into the kitchen, saying, as he did so :- 
"Can you not help me a little, Harriet?"

"With pleasure."

"I want these potatoes cut, so that I can plant them."

"Plant them? How can you? The ground is still frozen hard."

Without a word he went to the next room, and procuring a book opened it and pointed out a paragraph. I read it.

"So you intend to force potatoes."

"I mean to try something of the kind. I have no hotbed; but as it is nearly April, I am going to attempt 'forcing' by the aid of the sun alone."

"But can you do it?"

"I don't know. I can try it, and find out."

"A good idea," said I, seizing a potato, and preparing to cut it in two.

"Wait a bit. We don't know how to cut our potatoes yet. Let us see what the books say on the subject."

"Precisely."

Then my husband read, as follows:-

" 'Cut each root into two, three, or more pieces, according to the size, minding, particularly, that each piece be furnished with one or more buds or eyes." "

In an hour I returned to my sewing, having finished the potatoes. During the greater part of the day, heavy teams, loaded with manure, had been toiling through our gate and 
out upon the open field behind the house. After supper, I asked Robert what he proposed to do with so much material.

"Spread it on the land, and have it ploughed in as soon as the spring opens."

"But will it not be a very expensive operation?"

"To be sure. But, then, 'Nothing venture, nothing have.' I expect to spend three hundred dollars in manure alone."

"Three hundred dollars? Why, that is nearly half of our whole capital!"

"I know, my dear. But, without this expenditure, we can effect little or nothing."

"That may be true, but how are we to buy horses, ploughs, cultivators, carts, and all else to work with, if the manure costs so much?"

"I propose to do without them. We may come to own a horse by and by ; but it will not be for our farm-work."

"How, then, do you propose to cultivate your crops?"

"By hand. You remember our trip to New York?"

"Remember it! Shall we ever forget it? It was our.- "

"And do you recollect standing on the deck of the steamer, as we swept toward Hurl-Gate, in East River." "Yes." 
"Well, you know I pointed out to you on the shore, near the outer limits of the city, one of those little half-acre rnarket-gardens; filled solid with growing crops, the plants standing so closely together that they fairly touched each other, and hid the very ground from sight?"

"Oh! yes. And how beautiful they were with their squares of different shades of green! And, do you remember, sir, the headache you had soon after, and how I had to play nurse for the first time in my life?"

"Indeed, I do. And a charming headache it was, or, rather, nursing, I forget which. Now, I hope to conduct our little farm as those Dutchmen do their gardens. I mean to pack our crops so thickly on the land that there will be no room for horse or plough. In short, my plan is to 'farm by inches, and by hand."'

When I came downstairs the next morning, I found my husband very intently studying the boxes and pots of seeds which he had placed behind the stove, and, on looking at them, I found them covered with myriads of small green plants just thrusting themselves through the soil.

"See, Hattie, what heat, moisture, and darkness have done. They have forced these seeds to germinate in three days. But now we must move them into the light and air, or we shall soon lose them." Upon which he took them all up, and placed them near the window, in the sun, saying, 
"After breakfast, I must move them to the frames in the yard."

"Well, Robert, pray tell me how it happens that you know so much aloout such things. When and where did you study botany?"

"I will answer your question by asking you another. I graduated at Harvard, did I not?"

"Yes."

"Well, that will account for everything."

After breakfast, the plants were removed to the now dry and warm frames. The soil in them had been worked over and raked smooth, and looked very fine and nice. The boxes of seeds were placed on the soil, under the glass, and in one of the empty frames. Robert now proceeded to plant the potatoes I had cut up the day before. Opening a narrow trench with his hand, he packed the bits of potato, cutside down, as thickly as they could stand, just like herring in a box, then another row, and so on. When it was finished, the soil was smoothed over them, and they were plentifully watered from a watering-pot Robert had bought for the purpose. There were thirty-five rows, and eighteen in a row, making in all seven hundred and thirty "sets," as the books called them: The few potatoes that remained were carefully washed and - eaten.

By this time the weather had become warmer, and the 
frost was out of the ground. The next day, the third of April, was so mild and pleasant that I went out after breakfast to see what was going on. I found the entire field behind the house dotted over with small black heaps of manure, and two men at work spreading it thickly over the ground. Seeing Robert over by the woods with a yoke of oxen and a man holding a plough, I went toward them to watch their operations. Before going many steps I discovered the whole team approaching me. Taking a good stand I waited to witness the procession. First came a pair of sturdy oxen; then Robert, glorious in big boots and a mighty whip; next a huge plough tearing its way through the soil ; and lastly, Mr. Kempenfielder. Immensely entertained with the performance, I took out my handkerchief and cheered them on. They never took the slightest notice of me (at least Mr. K. and the oxen did not), but went sailing away and left me alone in the middle of the field. I put up my handkerchief, and started for home. But seeing them soon at a stop, I turned toward them.

"Well, Robert Nelson, I never expected to see you driving a pair of oxen."

"No more did I. It is my first attempt. Mr. Kempenfielder showed me how to drive them, and there you see the result." 
"The straightest furrow I ever seen drawed," said Farmer K. "I don't see how he did it."

"My army experience taught me that. When I was Sergeant of Co. 'F', 190th Mass., I, very quickly learned to draw a straight line across an open field by simply 'alligning' two distant objects." 'Taking out his watch Robert looked at it and exclaimed, "Why, it's ten o'clock! I had no idea the sun was so high. Please, Hattie, go and look at the lettuce-plants. If the thermometer in the frame stands at $70^{\circ}$, or higher, lift up the back of the sash, and put a stone or something else nder it to let the surplus heat out."

On going to the frame, I found the glass covered with steam. Looking at the thermometer I found it at $90^{\circ}$, while the plants seemed to be beaded with dew. Lifting up the back of the sash I propped it up about an inch with a bit of stick. Opening the sash where the potatoes were I found everything steaming hot ; butas Robert had said nothing about opening it, I let it remain as it was, and went into the house. At noon Robert came in and said I should have aired the potatoes. The heat had wilted them badly. So much for ignorance. He also said I must go out at about four o'clock, and let the sash down again to shut the heat in for the night; which $I$ accordingly did.

At six o'clock I went out to call my husband in to sup- 
per. I found him near the barn talking with Mr. Kempenfielder, who was preparing to go home after his day's work.

"It's a mighty heavy dressing you have put on your land, Mr. Nelson. I never seen the like in my life. It must have cost you a sight of money."

"It was a costly operation. But an extra heavy dressing will give an extra heavy return, I suppose. At any rate, it will not be my fault if the land does not yield her increase. In addition to all this barn-manure I shall put on about a hundred dollars' worth of superphosphates, lime, ground bone, and guano."

"A hundred dollars' worth! why, man, you're crazy. Who ever heard of such a thing?"

"I have, - or, rather, I have read of it in the papers. I think I have seen somewhere that the gardeners around New York sometimes put six hundred dollars' worth of fertilizers on one acre of their land."

"Perhaps they do. Them that has money can afford to throw it away in that fashion."

"I cannot positively say whether they can afford it or not. But I do know they keep throwing it away year after year, and I don't imagine they do it for amusement."

"I have heard tell of them fellows; but I don't believe 
mor'n half that's told of 'em. One of them came and settled round here a few years ago and tried sass-raising, just as you proposed; but, then, he was a poor shote of a fellow, and his farm soon drank him up, or he it, I don't remember exactly which. Besides you have a kind of manure which he did not have. He used plenty of the barn-stuff, but you seem to use more yet, and in addition put on to your land a better manure still,_brains." 


\section{CHAPTER IV.}

\section{SEED-TIME.}

Two days after this Mr. Kempenfielder had completed the ploughing and harrowing, and he and the laborers went away. In their stead Robert hired a lad from the village to work for us during the summer. $\mathrm{He}$ found a boarding place near by, and was to be employed on our farm all and every day, Sundays excepted. After tea, on the day the ploughing was finished, we walked out to inspect, and to make up our minds where we should place our various crops. - Our land consisted of a single unbroken field, with the house and barn placed near the road in the centre. Directly. through the centre a path or road-way had been laid out from the barn to the woods in the rear. This gave easy access to all parts of the place without wasting much space. All the remainder of the land had been thickly spread with manure and ploughed one way. Then it had been crossploughed in the opposite direction, and after being harrowed again and again the soil was reduced to a fine level surface. Little as we knew of such matters we could not fail to notice the thorough manner in which the work had been done. 
"What other crops than potatoes do you intend to " plant?"

"I hardly know as yet. We must consult Washburn \& Co., and the books. I have thought a good deal about it the past two days, and have been tempted to write to Washburn \& Co. for advice. For my own part I have no preference. Our only object is to raise such crops as will give us the greatest money return. If it pays best to raise radishes, we will do so. If we find more money in string-beans, we will establish a monster beanery at once."

"For my part, I think it would be best to consult the market-man. You hope to sell your crops to him, and he can tell just what is most in demand."

"Good! Harriet!. I'll go down and see him to-night, so .that we can order the seeds by to-morrow morning's mail. Despatch is the word, - I'll go at once."

So saying, he went toward the house, and I saw no more of him until nine o'clock. The order for the seeds was written and duly mailed early the next day. Soon after breakfast it began to rain. As little or nuthing could be done out-of-doors, Robert set our new boy - Jack by name - to work cleaning up the barn, and on returning to the house we both gave ourselves up to the study of our books. Reading and talking about our new profession filled up the entire morning. After dinner we again went at the books, and among other things 
we came to the subject of transplanting, or removing growing plants from one place to another.

"Must not those lettuce-plants be transplanted by and by ?"

"Yes; they will have to be transplanted twice, if we may believe the books. Once into the frames, and after that from the frames to the ground. This would be a good day to do it. I wonder if I had better not do it this afternoon. We may not have another cloudy day for some time."

"What! go out in all this rain?"

"To be sure. Why not? I can put on an old suit that the rain will not injure."

"It is not for the clothes I fear, but for you. The only result will be a severe cold, and perhaps a return of your illness."

"I do not fear that in the least. I will dress warm and not stay out long. If I feel the slightest chill I will come in at once."

- Thereupon he put on an old hat and coat and went out to get Jack to help him. As for me I was very uneasy at the whole proceeding; but my fears were groundless it afterwards proved. A short time after this $I$ went to the kitchen window to see if they had yet finished their undertaking, and I saw my husband and Jack gravely planting out the lettuce, and the rain pouring from their clothes in little streams. Vexed at Robert's foolhardiness, I rapped on the window and beckoned to him to come in. All the reply I 
got was a very wet smile and shake of the head. Quite provoked at what seemed mere folly, I returned to the diningroom and sat down in no pleasant frame of mind. Soon after I heard him come in and go upstairs. In a few moments he came down fresh, cheerful, and dry.

"No harm as yet, Hattie. Nor do I fear any. We planted both frames nearly full. We put them one inch apart each way, which gives us about three thousand five hundred plants. It took only a small portion of our plants. We have several thousand more in the boxes and pots."

To my surprise, no harm ever came of this venturesome proceeding. In time I learned to see my husband go out in all weather with complacency. Rain or shine, it made no difference; he never felt any ill effects from the exposure. Perhaps you will wonder at this. The only explanation I can give is, that a warmly clad person at work in the open air is too much occupied to stop to think about taking cold. Imagination goes a great way sometimes.

That night, thanks to the promptitude of Washburn \& Co., a large package of seeds came to us by express, and we spent the evening in examining them, and in making ourselives acquainted with their different methods of culture.

The following is a list of the contents of the package:-

Beans.

Beets.

Cabbages.
Cucumbers.

Peas. -

Radishes.

Turnips. 
Now it is impossible for me to give you a detailed account of all our doings. Sufficient is it to say that as soon as the warm weather opened, about the 15th of April, we went to work at our planting. I say we, for I was so much interested in all that was going on that I could not stay in the house, but, putting on a short dress, I joined Robert and his boy Jack in the field. We had had several showers and the soil was beaten down hard by the rain. At Jack's suggestion the ground was loosened with a hoe and then raked smooth.

As I told you before, the farm was divided into two parts by the narrow roadway or path. This path extended north. and south, and at the upper or northern end, next the woods, our first planting operations were begun. The first thing we took was beans, - string or bush beans, - the early yellow six weeks and early Mohawk. These were the two sorts we selected from Washburn \& Co.'s catalogue. Jack took the hoe and began to break up the soil; Robert taking a rake went after him raking it all smooth, while $I$ held the seeds and performed the part of "the admiring spectator." But this did not suit me. I could not be idle while others worked; so, as soon as a slight furrow had been drawn with the hoe, I began to drop the seeds about two inches apart, as the books directed.

"Wait a bit; we must not forget the phosphates. Jack, 
get a wheelbarrow and bring one of those barrels that stand in the barn."

Accordingly the superphosphate was brought and thinly scattered in the furrow or drill. When about half way up the first row I stopped. A new idea had come to me.

"Are you sure, Robert, that you have placed these rows in the right direction? Onght they to run north and south parallel to the road, or east and west at right angles with it?"

"I can't see that it makes any difference: The sun shines down between the rows, and they do not shade each other, if they are placed north and south. However, I suppose they will grow as well one way as another."

"That is not what I was thinking of. Suppose now your beanery was all up and in bearing order, and you wanted to gather a few bushels for market; will it not be very awkward to have to walk with a heavy basket half-way down one end of the plantation, then turn at right-angles, and go up between the rows in order to get to the centre of the field? You certainly cannot go stepping over the rows. That would be still more awkward. Now, it seems to me, if the rows were placed the other way, you could go to any spot you wished by the most direct route."

"Harriet you are-a - well, you are everything that's nice. Come, Jack, stop there. We will carry out her idea 
and turn our plantation round end-ways. Never mind the beans that are planted."

So we began again. Jack prepared the ground, Robert put in the fertilizer, and I placed the seed. After planting several rows I left them and went to the house to prepare dinner. As I passed the lettuce-frame I looked at it. The young plants were growing rapidly, and had stretched themselves up so that they covered the soil from view. Altogether it made a very pretty sight, - green, fresh, and thrifty. To my surprise I found the potatoes bad sprouted and were growingfinely. As I looked at them, I wondered how we were ever to get them out. They seemed to have quite grown together. While I was setting the table for dinner I happened to see Washburn's "Guide" on the table. "Let us see,- did I not read something about bush beans there? Oh! I fear we have made a mistake." At that moment Robert came in.

"What day of the month is this?"

"The sixteenth."

"Do you call this the middle of spring?"

"I should say not. It is early spring yet."

"Read this: "All varieties of beans are very sensitive to the frost and cold, and should not be planted before the middle of spring." "

Without a word he laid down the book, and, taking up 
"Burr on Vegetables," dived into it with the greatest eagerness. After turning over the leaves for a moment or two he closed the book and opened McMahon's.

"What are you looking for," said I.

"Some crop that will stand the frost and that can be planted early. We must be doing something if we are blocked at the outset. If we ought not to plant beans, we can try something else. Ah! I have it,-peas. Come, let us dine."

After dinner we went out to make a new start in the planting business. Marking off a large square having an area of about half an acre we began again. Having planted one row, Jack commenced to prepare another about three feet from the first.

"Hold on, Jack, - that won't do. We must not waste our land in that fashion. Make the rows nearer together."

Jack dissented from this. "Nobody ever planted nigher than three feet. Farmer Stamford, and Farmer So-and-so never planted less than three feet."

"Perhaps he is right," said I.

"Perhaps he is, and perhaps he is not. How much manure does Farmer Stamford put on his land?"

"Oh! a lot, - as much as ten one-horse loads to an acre."

"Ten loads to an acre! There are fifty loads here, 
besides the superphosphates and other fertilizers. You may make the next row eighteen inches from the last. There is my foot rule. We will measure the space off by inches."

We worked hard till six o'clock, and had the satisfaction of seeing our "pea-patch" nearly planted. While at the tea-table I was surprised to find the bread and butter disappearing very rapidly.

"Why, Robert, what is the matter? I never saw you eat so much."

"Eat so much! It is you that are doing the eating. I am quite ashamed to see that you have eaten so heartily."

"Well, I was hungry."

"So was I."

Upon which we had a good laugh at each other. Our out-door work had given us both wonderful appetites.

"We are very unfashionable, my dear."

"To be sure we are, but good health is unfashionable also."

The next day was a real April day. Clouds, sunshine, and showers, delightfully mixed. I did not venture out myself. Robert and the lad finished the peas before we had much rain, and at about ten, I heard them at work near the lettuce-frame. Throwing on a waterproof I went 
out to see what was going on. Jack was holding a large flat basket, while Robert was carefully prying up the - potato sets with a flat stick. He was obliged to be very careful, as the small shoots that had started from the eyes were very tender and brittle. At first many of them were broken in handling; but he soon learned to dig them up without injury. When the bottom of the basket was covered they started for the field, and I after them. First the boy stirred up the soil, then my husband opened the ground with his hands, scattered a little guano through the soil, and taking one of the potato-plants carefully set it in the ground, leaving the green tips just showing through the soil. As for me, I carried the basket. In about two hours we had finished the work, leaving the plants three feet apart each way.

Several showers passed over while we were busy, but we let it rain. For my own part, I rather liked it. It was a novel sensation to be out in the rain with no umbrella. What would our city friends have said if they had seen us? It is true, my dress became fearfully soiled; but it was an old affair and could be easily washed. Just as we were going to dinner I looked back over the newly planted field. It seemed very thinly occupied, and appeared wasteful as far as space was concerned.

"Can we not grow something between the potatoes, Rob- 
ert? Is there not something that will come to maturity before these plants cover the ground?"

"Just what I was thinking of. We will consult the books after dinner."

But the books did not help us, and we were thrown back on our own resources.

"How would beets do?"

"Not at all. It would take so long for them to come to maturity, that the two crops would crowd each other and become mixed up in inextricable confusion."

"You don't understand me. I mean beets as beet-tops, not as roots."

"Oh! ah! I see what you mean. Sow the seeds thickly between the potatoes, and then pull them up and sell them when the tops are young and tender. Sell them for greens."

"Precisely."

"Well, Harriet, all I can say is, that you will make a capital farmer if you keep on. Where did you acquire so much brightness?"

"Caught it-just as one would the measles - from my husband."

That evening we had a call from our neighbor, Mrs. Jones. She proved to be a lady of good sense and education, and well acquainted with the best literature of the day. We were both vastly entertained by her visit. She had. 
views of her own on all subjects of interest. Art, music, and politics were familiar matters with her. Among other things we touched upon our farming operations.

"I have heard of your doings. It has made a good deal of talk in the village already. They all seem to think you will make a .wretched failure of it. I tell them to wait. It is not the first time a city-bred man has tried farming. Many have done so, and succeeded too, which is more than can be said of some regular farmers. You intend to confine yourselves to garden crops, I hear."

"Yes. It is purely an experiment with us. We only intend staying for a few months, and while here we follow the business of gardening for a support."

"I am glad to hear it. I should really like to see some such active young people as you are make the experiment, and then give us the result. Perhaps you could settle the vexed question, Does farming pay?"

"If we fail in every other respect we can at least do that. We can show by our books just what it does cost, and ascertain how much profit there is in it."

"I am glad to hear you say this. Farming, as carried on about here, is a haphazard affair. They never seem to know precisely where they do stand, whether they are making or losing money. Can I help you in any way? My husband when he was alive was a skilled gardener, though 
he did not follow it as a profession. I wish he had. He might have lived to this day instead of grinding his years away over his desk."

"Thank you, Mrs. Jones. Doubtless you can help us. For our own parts, we know little or nothing beyond what we have acquired from books."

"Books! - what do you want more? Books, with brains, and I fancy you can both furnish them, will accomplish anything. I have quite a library of agricultural books. I shall be happy to loan them to you at any time."

"Thank you, we shall be delighted to avail ourselves of your kindness."

"That is right. I sometimes fancy that books love to be read by people who appreciate them. Come and see me tomorrow' evening, and I will place my whole library at your disposal. It will be a pleasure to see my books once more in use."

The next day opened fair, but soon clouded over and remained so the rest of the day. Robert at once took advantage of the shade afforded by the clouds to plant out the lettuce-plants. I did not assist him about it, but went out once during the morning to see how they prospered. As we were determined to use every foot of our land, it was a matter of importance not to waste any by planting too far apart. To make sure of having the young lettuce-plants 
stand just twelve inches apart, Robert made a marker, as he called it. I called it "Nelson's Patent Lettuce-planter." It was simply a ten-foot strip of board, having small pointed wooden pegs fastened to it every twelve inches. By holding this over the soil and letting it fall, ten small holes were made in the soft earth. Into these the roots of the plants were dropped, and with a slight pressure of the fingers they were fastened upright in the ground. The planter was then used again, and so on. After trying it a few times they became quite expert, and when I came out to see them they were setting out the plants at the rate of three a minute. When I again went out, to call Robert in to dinner, the entire three thousand five hundred had been set out, and they had begun again on the lot of plants that were still growing in the pots and boxes. But here they met with a difficulty. The plants were growing so close together that on pulling them apart they were found to be drawn up very thin and weak.

"So much for not knowing that they should be planted out in a frame to give them more room, and make them stocky. They quite starved each other, and are valueless. We are a long way behind our forty-three thousand plants, Harriet."

"I know it; but can we not try again? Can we not sow more seed, and transplant them before they are too old?" 
"I do not know, I'm sure. We can but try it."

After dinner, Robert prepared a new bed in the frame, and sowed lettuce-seed all over the soil. This he did to force the plants along, intending to plant them out in the field as soon as they were large enough. About half-past five I went out once more to inspect things. The frame had again been planted with lettuce, and all the spare land between the young potato-plants had been raked over, and beet-seed thinly scattered and raked in. I found the two people at the farther end of the place preparing to make another plantation.

"What do you propose to put here, Robert?"

" Turnips."

"Why, I thought they were only useful as a late crop, planted in the fall for winter use."

"So they are; but do you not remember seeing small bunches of white turnips in the market, at home, in June?"

"Yes; we used to pay a shilling a bunch, and were glad to get them at that price."

"Just so; it is that shilling which has induced me to try turnips as a spring crop."

"A good idea ; but, come, supper is ready."

As we walked slowly along the path toward the house we passed the new lettuce plantation. 
"Is that not a waste of room, Robert? Can you not grow something between those plants?"

"Now, Hattie, you are going too far. That is carrying things to a pretty fine point. There are only twelve inches between the rows now. In thirty days the lettuce-plants will touch each other."

"Perhaps so ; but is there not some small quick-growing crop we could get off before the lettuce reaches that point?"

"I am sure I cannot think of anything, and I doubt if you can."

"Don't be so sure, sir. Wait till I can consult our books."

On reaching the house I examined "Burr on Vegetables." After a short search, I found these words: "If space is limited, radishes may be sown with onions or lettuce." 


\section{CHAPTER V.}

\section{WHAT IT DID COST.}

The following evening we called on our new friend and neighbor. As we walked up the gravelled path, and approached the little cottage where Mistress Comfort lived, quiet strains from a reed organ, skilfully played, greeted our ears. The door was opened for us by Comfort herself, who looked and spoke a comfortable, cordial welcome. If we had been surprised to hear the music in such an out-ofthe-way place, we were still more astonished and delighted on entering the brightly lighted parlor. A two-banked organ, pictures, books, comfortable furniture, and a glorious open wood-fire. Could any city parlor furnish more? And the lady of the house, - did she just step from a glass case, or is this all a dream?

"You seem surprised."

"We are, madam. We thought country people were well - not like this - rural."

"You must have got your ideas of the country from the opera,-pretty but ignorant shepherdesses, gay with ribbons ; or from story-books, - the men bowed down by labor, and the women only capable of gossip and bad grammar." 
"For our own part we were ignorant. Others told us that on leaving the city we should bid farewell to all that makes life endurable; that dwellers in the country never rose above the clods in which they delved, or had an idea beyond cows and such things. If one may judge from the specimens the country sometimes furnished.the city, they were not so far wrong."

"It is true, a portion of the agricultural community are so weighed down by toil that they seem but little above their own cattle; yet, for all that, you will find, in a given number of country people, just as much virtue, refinement, and education as in the same number of city people in the same circumstances in life; no more and no less. The only difference I can see between the town and country is, that in the country there are no very poor, no very rich. Human nature is the same everywhere."

We had quite a lively debate on this point, after which conversation branched off to other matters. A more delightful evening we never passed. Our host exhibited her pictures, played for us, and lastly loaded us with books to take home and examine at our leisure. As we rose to go, Robert said :-

"Please, Mrs. Jones, may I ask one more question? How happens it that you prefer living in this retired spot, when your wealth and tastes would so naturally lead you to 
the city, among all the advantages of concerts, lectures, and society?"

"Simply because I am not wealthy. A little money goes a great ways in the country. The cost of living would be so much greater in the city that all my income would be expended on my support; that is, such a support as I should desire. Here the cost is so much less that I can indulge, as you see."

This set Robert thinking, and all the way home he was as quiet as a mouse.

The next day the planting was resumed, and by the first of May all was finished, save the beans and cucumbers; these we left until some time after. Would you like to view the result of my husband's labor? Come and see. The day is mild and bright, the ground dry and clean. Birds sing in the air, and a green mist seems to float in the woods. The grass by the roadside is bright and fresh. Far down the valley the river sparkles in the sun, while the hills, marked off in various patterns, show where the fields are planted with varied crops, and every crop a different shade of green; blue sky and flashing water; purple mists on the far-away hills; a hundred shades of green on every hand, and over all a flood of light. Now for details. As we go up the path extending through our little farm, the first thing we see is a long, narrow bed, or border, reaching 
from the path to the fence. It is four feet wide, and one hundred and seventy-five feet long. Thickly dotted over it are thousands of delicate leaves just breaking through the moist soil. This is Robert's seed-bed. The plants are cabbages. By and by they will be carefully transplanted to some other place. Next we come to a broad strip of land, covered with solid ranks of peas, about three inches high, thrifty and vigorous. Here are our thirty-five hundred lettuce-plants growing rapidly, while between every row a narrow thread of green shows where our radish-plants are hastening to maturity. Beyond these is another and larger lot of lettuce. These are quite small, having been planted later than the others. There are about ten thousand little plants dotted at equal distances over the ground. The same delicate thread of radish extends between the rows of plants as in the other lot. Here is our turnip-field looking finely. The rows are very thickly filled with plants, but Jack is busy thinning them out by hand. He has two boys to help him, for it is no small job. Every plant has to be * examined; the weak ones pulled out, and those that are to remain left standing about four inches apart. There is half an acre of plants, - at least twenty thousand. If we get half a cent apiece for the turnips, this little plantation will yield us one hundred dollars; so you see, as far as money is concerned, our farm already presents a cheerful aspect. 
Beyond the turnips are the early potatoes, and among them the reddish-green leaves of the beets are spreading over the ground, and filling all the spare room. Lastly, is the empty space where we began to plant the beans. They never came up at all. On digging a few up to see what was the matter, we found the seed quite mouldy and dead. We had lost our labor and the seed by planting too early. The spring rains having beaten the soil down hard, Robert and Mr. Kempenfielder are at work upon it with a horse and light plough. Mr. Kempenfielder is leading the horse, and Robert holds the plough. They have stopped to turn at the end of the field.

" You have held a plough before, aint you?"

"Never touched one before," said Robert.

"You can't tell me that. You hold it as if you had done so a year."

"Do I? It is only because I imitated you as nearly as I could. This is my first lesson in ploughing."

"Then you beat all I ever see. My boy Tom took mor'n a month to learn to plough."

"How so? Was he not a bright boy?"

"Bright as a dollar; but somehow he never could seem to give his mind to it. He was always a-reading books and wanting to go to sea."

"Did you let bim go?" 
"Yes. It went agin us, but his mother and me finally give in, and he went. He never would have been contented on the old place. He said it was too lonesome and there was too much work about it. He wasn't far wrong there. Farming is dreadful hard work, and no mistake. You'll find it so, I reckon, before you get through the summer."

"I have not found the labor very severe as yet; but then my farming is quite different from yours. Come, start up your horse. We have no time to lose;" and away they go, horse, plough, and all.

In about an hour the work was finished, and the whole team came slowly down the path, just as the factory whistle blew long and loud for dinner. As they passed the lettuce-beds Mr. Kempenfielder stopped and asked what they were.

"Lettuce and radishes."

"You don't say. All them lettuce? What can you do with such an everlasting lot of them?"

"I hope to sell them."

"And what do you expect to get?"

" A cent a head."

"Only a cent. Why there aint more than eight or nine hundred all told. That won't bring you much."

"It would not be a great deal if there were but nine hundred. According to my counting there are over thirteen thousand plants in that lot." 
"Thirteen thousand! Why, at a cent that would be over a hundred dollars. A hundred dollars off that pocket-handkerchief piece of land!"

"That is the way I figure it. Besides the lettuce, I hope to get a bushel or two of radishes off that same ground."

"Radishes! Where are they? I don't see 'em."

"Right before you, between the lettuce-plants."

"What, them little things? Lor! I thought they was weeds. Well, well, it's a kind of farming I could not follow. I should have to wear my specs all the time to see the crops. A hundred dollars off that place; but after all, it must have cost a sight to raise 'em."

"It did cost something, but not a hundred dollars by any means."

Now, perhaps you, like Mr. Kempenfielder, would really like to know what it did cost, - how much money my husband has sunk in our operation thus far. Seeds have been bought, manure has been spread with a lavish hand, and the labor must have cost something. I myself became a little uneasy to see the money go so fast, and one evening, about the first of June, we sat down to make an examination of our ledger. Robert had not been so careless as to go blindly on spending money without a thought. I found he had the whole thing at his tongue's end and knew to a cent just where we stood. 


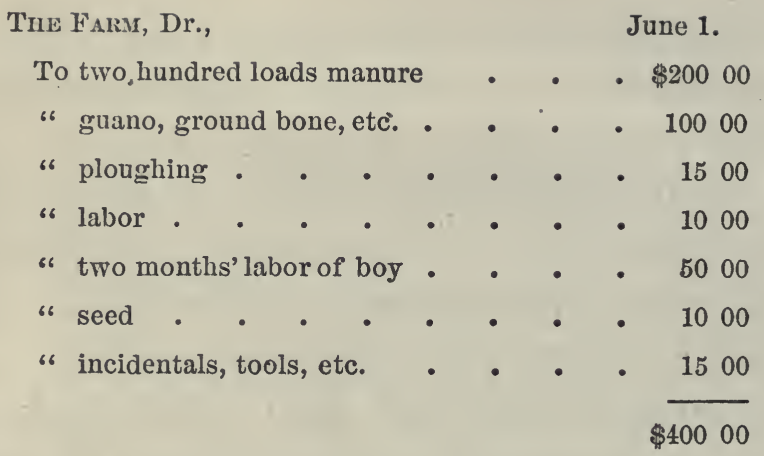

Four hundred dollars so far. No return as yet. In addition to this we must enter our support for that time, but we will leave this till we come to the final summing up of our affairs in October. My husband's labor should also be added to the cost of our farm; but that, too, we will defer for the present. Whether we shall receive enough from the place to pay him for his toil remains to be seen; however, the prospect is cheerful. 


\section{CHAPTER VI.}

\section{OUR FIRST HARVEST.}

WrxH the advent of June came the first real, downright, hard work, - weeding. It was a novel experience with us city people, to discover the charmingly independent way the weeds had of coming up at all times and in all places. Little did they care for our pet lettuce, or beloved radishes. They (the weeds) came up seemingly in a night, and in the very place they were least welcome. In fact, they were not welcome at all. $\Lambda$ s soon as they made their appearance we went forth to receive them with all honors. Getting our tools, we started out "like an army with banners" (hoes), and made a vigorous attack on the first we met. They were among the young cabbage-plants in the seed-bed. We very quickly found our hoes were quite useless here. The only thing to be done was to carefully pull them out from between the plants. After a while I was obliged to give it up and beat a retreat to the house, leaving Robert and the boy to finish the undertaking. The labor was quite beyond me, requiring more endurance than I could command. Just before noon the seed-bed was finished. At dinner-time Robert came in, looking tired, flushed, and hot. In a few moments 
he was ready to come to the table, having washed and dressed for dinner. This is something he never omitted. If he did farm for a living, there was no occasion for his sinking the gentleman. He did not follow the example of some of our farming neighbors, and come to the table in his shirt-sleeves, but maintained the same habits he acquired in the city. Promptly at one o'clock the work was resumed. As soon as I had finished clearing away the table I went out to see how they prospered. To my surprise I found them at work among our newly planted beans. I had supposed they would take things in order.

"What induced you to skip over so many things, Robert? Why did you not take the peas next?"

"Beans must not be hoed when they are wet, - makes them rust. They are dry now."

"6 Who told you so much?"

"Books." And he rapidly plied his hoe, throwing in the words between the sharp ring of his tool, as it slid over the ground, gently stirring the surface and setting the young weeds adrift. The sun was shining brightly, and the weeds as they lay scattered about on the warm soil soon wilted away in the heat. Just where they were at work the soil was fresh and brown beneath them, a few feet behind it changed color, and a yard or two back it was quite dry and - dusty. This to me seemed very singular. I did not know 
that the soil would part with its moisture so quickly. While thinking about this, a new idea came to me. Is there not a better tool, and a quicker way of doing this work? The hoe Robert is using is only six inches wide, and each stroke tears up a strip of weeds the width of the blade. Would not some other tool do the work as well, and in half the time? Without a word I went back to the barn, and procured a light iron rake. Selecting a spot where the . weeds were pretty thick, though very small, I began to draw the rake back and forth over the ground, as if for my own amusement. After going a rod or so I threw it down, and went over to where Robert was at work, near the fence. As I approached I discovered that Robert and the boy were not alone. There was a man, a farmer apparently, and a stranger, leaning on the fence and talking with Robert.

"It must have cost you a sight to have fixed things up as slick as you have here?"

"Certainly it did," said Robert, still swinging his hoe and talking at the same time. "It has cost several hundred dollars already."

"Several hundred dollars! You must have plenty of stamps to be throwing them away in that sort of way."

"If I supposed I was throwing money away, I would stop at once, and not spend another cent."

"You'd better stop any way. Farmin' never did pay, 
and I don't believe it ever will. The more land a man has, the poorer he is off."

"The first part of your proposition I doubt, the last part I can understand readily. If I were obliged to cultivate a hundred acres I would give up at once, and turn to some other occupation."

"I've got two hundred on my place. Its the old Stamford farm, next door. My father left it to me, and I've managed to starve on it all my life, and my children too, - that is, what's left of them. The boys ran away; the girls can't, so they don't. They is willing enough, I dare say. Well, I don't blame 'em. Farmin' is a dog's life, and mighty poor pay, unless perhaps a fellow has lots of capital."

"There is one kind of capital you have as much of as anybody."

"What's that?"

"Time! All the while you have been standing there leaning against the fence, doing nothing, I have hoed a whole row of beans, and have thereby added to their value at least fifty cents."

Finding the conversation becoming pointed I went back to examine the result of my labor. Just as I supposed, the rake tore the weeds out of the ground, and the sun quickly killed them. I cannot see but that the work is as well done as with a hoe, and better in one respect. 
"Robert, please come here and bring your hoe. If you have a foot-rule, please measure the blade of your hoe, and then measure my rake."

"I have no rule, but can place them side by side and compare the width of each."

Taking up the tools he laid them side by side.

"The rake is more than twice as wide as the hoe; if the hoe is six inches, the rake is more than twelve. I see what you'are aiming at, Harriet. You think the rake will do twice as much work as the hoe; that every stroke will go over a greater space, and consequently there will be a saving of time and labor. A good idea, but will it work? Will it do as well? Can you kill the weeds by raking them up?"

"Come and see."

"I declare, Hattie, that is a success. How came you to think of it?"

" Pure inspiration. Country living has clarified my brain. I shall expect to shine" -

Looking up, I discovered that the man by the fence had climbed over, and was standing near, with his hands in his pockets, staring open-mouthèd at our doings, and saying :"I swaney if she aint got a head-piece. Who'd a-thought it would work so? Every weed's killed. I don't believe Sally or Jane would have done it." 
"Hallo, Mr. Stamford!" said Robert,' " where did you come from? I was afraid I had driven you off. This is Mr. Justin Stamford, Harriet, our next neighbor through the woods."

"Glad to see you, ma'am. You is the first lady I ever see that showed a spark of interest in farmin'."

I returned the salutation as well as I could, being somewhat amused at the queer mixing up of heads and rakes.

Taking up the rake, Robert went to work, raking the weeds instead of hoeing them, leaving me to entertain Mr. Stamford. This I was not inclined to do. It was nearly four o'clock in the afternoon, - high time all reasonable people should be about some regular employment. Yet here was this man, idly stopping to talk; and talk he did, in a straight line, till I could stand it no longer; so, as politely as I could, I escaped to the house, much wondering at the man's utter indifference to the value of time. Perhaps he is a man of property and leisure, thought $\mathrm{I}$. He don't look it, and he says he has a two-hundred-acre farm. How is it possible he can have any leisure at this time of the year and with such an estate?

So the days sped away and the summer was at hand. Our days were devoted to the farm, and our evenings to reading for profit or pleasure. We read all the agricultural books we could obtain from our neighbor, Comfort, 
besides taking the "Cultivator and Country Gentleman," the "New England Farmer," and other rural papers. In these we found a vast fund of valuable information. We could not understand it all at first, but after a while we learned the meaning of the technical terms, and then it was easy enough. The only thing that troubled us seriously in our reading was the immense number of details and minute directions for doing things, and, what is more, every writer seemed to have a pet method of his own, and gravely informed the reader that his way was the only one to be followed. As we oftentimes found a dozen articles upon a given subject, and all proposing a different style of doing a thing, it was somewhat embarrassing.

"What shall we do, Robert? One man says, do it my way; another says, no, my way is the best; and a third offers still another plan. They all say they have each tried their own method, and succeeded also. How can that be?"

"They are all more or less right. There may be several ways of performing some agricultural operation, and each having some one point of advantage over the other. All we can do is to select the method which seems the most simple and the nearest to common sense."

Here is a list of a few of the books we read:"The Field and Garden Vegetables of America," by Fearing Burr; a useful and valuable book. 
"The American Gardener's Calendar," by Bernard McMahon. This had the operations of each month placed together, - a great convenience. The only trouble with the book is that it attempts too much, and confuses the novice.

"The Elements of Agriculture," by Geo. 亡. Waring; a scientific work, but plainly written, so that it can be understood by any one of ordinary education.

"The Chemistry of the Farm and Sea," by J. R. Nichols ; full of information, but, for all that, not a book which would aid us greatly. We did not spend much time over it.

"The Field-Book of Manures; or, the American Muck Book; " by D. J. Browne, stuffed with information like a chicken ready for dinner, and, like some stuffed meats, requiring brain-sauce and salt to go with it.

"A Manual of Agriculture," by George B. Emerson, and Charles L. Flint. This we found to be a school-book; as we were not above going to school, it helped us wonderfully after we had found time to master it. During our first experience at farming we gained but little from it, as it required study to understand it all.

"The American Home Garden," by Alexander Watson; a useful and sensible book. Yet to read it one must have some knowledge of gardening beforehand. Not having it, 
we could not avail ourselves of the book till some time after we began business as "sass farmers."

These all and many others we read as carefully as we could, and gathered from them what help we needed. At that time Henderson's " Gardening for Profit" was not published. If it had been, we could have saved ourselves many mistakes.

About the first of June Robert started off one morning for the village, "to buy a team," as he said. About noon I heard some one drive into the yard, and on going to the door I found Robert, with an animal, - a horse they called it, ancient and bony. On the creature's back was a light harness, whole, but decidedly old. Behind the beast was a small open wagon with one seat. If the horse looked old the wagon seemed older still.

"How do you like my team, Harriet? Lovely creature, is he not? His neck is not 'clothed with the thunder,' but it has a good collar on. The valley does not tremble 'when he paweth it;' and when he 'smelleth the battle afar' he don't say a word; yet he can drag a load of potatoes, to say nothing of lettuce, and he'll do."

"How can you talk so, Robert? What did you buy such an establishment for? I am sure I shall never ride in such a thing."

"It is not for our riding that I got it, but to carry our crops to market. The day of our prosperity is approaching, 
and you can tell any of our city friends you write to that we now keep a horse - and cart. How much do you think I paid for my team?"

"I am sure I don't know."

"Just fifty dollars for the wagon, horse, and harness. It will carry our crops to market, and we can sell it when we return to the city, if we ever do so."

"Do you think there is any doubt about our return?"

"Yes; my health is so much better since $I$ have lived in the open air.that I am half inclined to stay out under the sky for the rest of my days."

"How about our support in that event?"

"That is a question I imagine this rickety old wagon will soon settle."

It did settle it in a measure the very next day. Just about daybreak the next morning Robert started off to market for the first time. He returned in time for a late breakfast, and as he rose to go to his work he placed a blank book and a small roll of bills in my hand, saying, as he did so, "Our first sales, Hattie."

3 bushels of beet-tops, at 75 c. . . . . $\$ 225$

12 doz. lettuce, 50c. . . . . . . . 600

6 " bunches of radishes, $\$ 100$. . . 600

$1 \mathrm{bbl}$. of peas . . . . . . . . 800 
That evening Robert was late to tea, so I went out to see why he did not come. I found him by the barn, with a huge pile of radishes before him on a rude bench. He and the boy were busy tying them up in bunches of ten each.

"Slow work, is it not?" said I, taking up a few, and preparing to make up a bunch myself.

"Yes, it is very slow. At this rate we shall have to hire more help soon in order to gather our crops. The peas are rapidly ripening, and the lettuce is all heading up at once."

"How would it do to employ girls about your picking?"

"I don't know. I never thought of it."

"It would be worth trying, at any rate."

"Do you think we could find any girls to work for us, Jack?"

"Can't say, sir. Never heard tell of such a thing before."

"Can you not ask Mr. Kempenfielder, or Mrs. Comfort? Perhaps they could help us," said I, tying my bunch with a piece of string. Just then a new idea came to me: Is there not some better way of doing this?

"Would we not save time if we divided the labor, Robert?"

"How so?" 
"Why, you make up a bunch, while I get the string and tie it when you are ready."

"A good idea; only you must not use twine. Take some of that Russia matting soaking in the water-pail. Twine would cut the roots, and injure their looks and sale. The matting is soft and easy to work with while it is wet. When it becomes dry, it shrinks, and holds the bunch tightly in place."

Robert then made up the bunches, and I tied, as he held them. By so doing, we got on twice as fast as before.

"Still another idea, Robert. Suppose, instead of your flesh and blood fingers, we had some wooden ones."

Without waiting to even thank me for the suggestion, he dropped the radishes, and went into the barn, and $I$ soon heard him at work with hammer and nails. In a few minutes he returned, bringing a small wooden rack, or frame, looking like a reduced saw-horse. Placing it on the bench, he threw a few radishes into it and tied them up in an instant.

"You place them, and I will tie them."

Soon we had quite a pile of bunches before us.

"Lend a hand, Jack. Take them away and wash them, while we tie them up."

At the sight of our improved method the lad opened his eyes very wide, and said:- 
"See what larnin' will do. Goodness! If I had sich a head-piece as that, I wouldn't be the poor devil I am."

Robert was up at daylight the next morning as the team was not quite ready for market. He and Jack worked hard, and at half-past five Robert dirove out of the yard with his wagon piled up with boxes and barrels. After breakfast I entered the following in my account-book : -

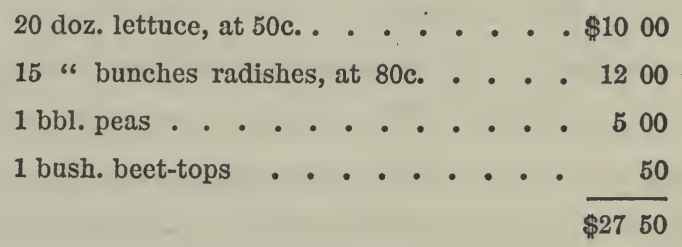

After dinner we both walked over to neighbor Kempenfielder's, to see if we could get any helpers to work for us on our place. As we approached the house, we caught sight of a far from charming picture. There stood $\mathrm{Mr}$. $\mathrm{K}$. in his shirt-sleeves, and at his heels were three unruly children, screaming and making themselves generally disagreeable. At the windows were two girls, about ten and twelve years old, while a boy was chopping wood near the door. Two dogs, a cat with several kittens, seven cows and a calf, also assisted in the tableau. The house, a large, old-fashioned affair, was flanked on one side by a huge barn, with its door idly swinging in the wind, and on the other by a rickety shed, filled with all sorts of carts, wagons, and tools 
in various stages of decay. All around the garden was a low stone wall, decidedly dilapidated, literally one stone falling from another. Though the day was warm, every window in the house was closed, and as we entered, it was like going into a musty garret. The lady of the house, fat and forty, if not fair, opened the door and ushered us into the best room, crowded with uncomfortable furniture placed with mathematical precision about the room, and drawing up the curtain let in enough light to make things visible. After the children had been quieted and sent out of the room, Mrs. Kempenfielder opened matters by remarking on the weather and crops. From this the conversation slid to our doings on our own little farm.

"We are very busy just now picking peas," said my husband; "we have so many, and as the price rules high, we are in search of pickers."

"Labor is plenty enough," replied Mrs. K. "My husband had lots of it offered to him; but we don't keep but two men. It is as much as your life is worth to get their pay out of the place, to say nothing of anything more."

"Indeed! I supposed you kept at least ten or twelve men on such a large farm as this."

"Ten or twelve men! Lor, bless you, no! Who could stan' it? Two's bad enough."

Just then, Mr. K. entered. He had procured a coat, and 
was plainly ill at ease in it, or in the room, I don't know which. Evidently the parlor was for show and company.

"It is labor you are looking for, - is it? Plenty of it round, such as it is, - Irishmen and Germans."

"We are not in want of men at all. We want young people, - would prefer girls."

"Girls! girls to work on your place?"

"Certainly. The work is light and not difficult."

"I never heard of such a thing before. Girls work on a farm! - not much. It would kill 'em right off. A girl or woman might as well hold the moon as a plough. You nor I will never see such a thing as a woman at work out-of-doors, and, what is more, I hope we never shall. My daughters never will, at any rate."

"You know, sir, a great deal more about farming than I do ; but I cannot see what objection there can be if a girl or woman assists about a farm, - picking peas, tying up turnips, gathering strawberries, or any occupation requiring a quick eye and ready fingers. There are hundreds of young girls, daughters of poor men, who would gladly earn something for their own support if they could know how, and were not afraid of Mrs. Grundy."

"Who is Mrs. Grundy?"

"The old lady who lives next door, and always says "They say," said I, coming to the rescue. 
"You don’t mean Mrs. Stamford," said Mrs. K., firing up suddenly.

" $\mathrm{Oh}$, dear, no. Mrs. Grundy is not a woman at all, or rather she is all women."

This puzzled her mightily, and she relapsed into silence.

"Perhaps you are right, Mr. Nelson, yet I fear you will not find what you want about here. None of the native girls would come down to such work. They'd be glad enough to get the money, but the working for it would stop 'em sure."

Finding we were to get no assistance, Robert turned the conversation to other matters, and after a while we bade them good-afternoon and walked on toward the next house, just beyond the woods.

"What an unlovely home!"

"Yes, and what a life! It is not living at all ; it is mere existence."

"Vegetating."

"Well said, Harriet. Those people haven't an idea above potatoes. Oh, if that is farming, may I never be a farmer! I don't wonder the son ran away."

"But need farm life to be so sunk in toil and ignorance?"

"I am sure I do not know. Perhaps these people we are coming to can tell us. I suppose this must be the Stamford 
place ;" for we found ourselves standing before a small cottage house with a pretty flower-garden ' by the front door. On either hand wide-spreading meadows lay warm and fair in the afternoon sun, the breeze just stirring the tall grass and waving grain. A noble great barn stood behind the house, and everything betokened neatness, order, and substantial comfort.

"What a splendid farm!" said Robert.

"And what a charming home!"

"Let us go in, by all means ;" and we did.

Mr. Stamford was a-field, but his wife and two daughters welcomed us kindly. We found them to be pleasant and well-informed people, without a trace of rusticity. This surprised us, as we supposed, from what we had seen of $\mathbf{M r}$. S., that his family would be oppressively rural. . The true explanation of this came out afterward. Among other things mentioned during our visit was the matter of "pickers."

"Just the thing!" exclaimed the elder of the young ladies. "Why should not girls work out-of-doors in the fresh air and sunshine? I am sure I wish I could."

"Father would never let you, Jane," said the younger. " He and mother attend to everything, and do not let us do anything about the house or farm. It is nothing but mend and sew, sew and mend with us; or it is read, read, read, 
all day lóng, till we have read every book and paper we can find. I wish father would work less and read more, and let us work more and read less."

"Hush, Sally!" said Mrs. Stamford, reprovingly. " Your father, as you well know, grants every reasonable wish you have."

"Yes, mother, all except the very reasonable desire for some regular employment."

"How can you talk so before Mr. and Mrs. Nelson? Doubtless they quite agree with your father."

"To tell the plain truth," said Robert, "we do not agree with him at all."

Fortunately, just at this point, Mr. Stamford himself entered the room, and the conversation was diverted to other channels. In a few minutes, however, it wandered back again.

"Perhaps you could work girls on your place if you had 'em, but I dunno where you'd find 'em."

"I I would go in a minute if I were not-were not-so far advanced in years," said Jane.

"So would I," said Sally.

"Come, girls, do talk sense or not at all," broke in Mr. Stamford, testily.

Seeing rocks ahead, and fearing a wreck, Robert skilfully steered one side, and sailed away on another tack. 
When we left Mr. Stamford's, we went home by the way of Mrs. Jones'. As we passed her house she beckoned us in, and while there we mentioned the employment matter. The idea seemed to strike her favorably, though she confessed she could not help us about it. At last she brightened up, and said she saw a way out of our difficulties, advertise.

The next evening, the "Arenac Plaindealer" contained the following :-

"Wanted, at once. A few smart, active girls to work in a market-garden. The labor is light, and the pay reasonable. Apply to

"Robert NeLson, Upper Road." 


\section{CHAPTER VII.}

OUR LEDGER.

The next day but one we had a queer commentary on Messrs. Kempenfielder and Stamford's ideas of female labor, by finding twenty-one girls and sixteen boys paraded in our yard, all eager to obtain the "light work, and reasonable pay." The boys we rejected at once. Why they came at all is more than $\mathrm{I}$ know ; perhaps they were modest, and thought they could do a girl's work. Selecting six of the brightest-looking girls, we dismissed the rest, and they went back to the village sadly disappointed. Our six pickers were soon introduced to the "pea-patch," and, as we were quite as ignorant as they as to the best method of picking peas, we let them help themselves about it. However, they were bright, and quickly learned that the true way was for each to take a row, and pick clean as they went. We paid them by the bushel, and thereby induced a lively competition, which resulted in our mutual benefit. After they had gleaned the peas, Robert set them to work tying up turnips, in bunches of four each. Jack pulled the roots, trimmed the tops, and brought them to the girls in the 
barn, who, after tying them, washed and packed them in boxes for market.

Robert took a full load to market the next morning. He did not return as soon as usual.

" Had to find a market this morning, Harriet. Our store would not take my whole load, so I drove round to the other storesy however, I sold out, and there is the account and the money":-

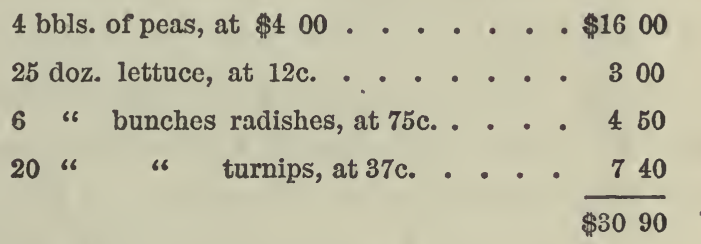

The six girls we retained in our service several days, and then, as the rush of work was over, discharged four of them, keeping two for a while longer. The four who were sent away were sorry to leave. The two who remained worked rapidly and well, and seemed to enjoy their occupation. Part of the work would be considered by many very dirty. Neither we nor the girls thought so. A pile of turnips covered with earth is not a lovely sight, and to handle them seems very disagreeable; yet good common loam is not dirty; it washes off easily and leaves neither stain nor smell. I have tied up many a bundle of radishes and turnips, 
yet my hands will compare favorably with those of any lady in the land.

The two girls took to their work kindly. They even offered to do that which we did not expect of them. They perfectly gloried in pushing a rake over the ground after a shower; and when it came to setting out the cabbage-plants, after the peas were gone, they took hold of that, and beat Robert and Jack in the quickness and neatness with which they set out the young plants. The girls stayed with us about a month, and during that time gave entire satisfaction. When they left us we found that they had improved wonderfully in health and strength, and as they went away, I could not help remarking that they were two of the most robust and hearty girls I had ever seen. To be sure, they were very much sunburned, and rejoiced in freckles; but I have yet to learn that a sun-tanned face is a disgrace, or that freckles are a bar to happiness. So much for the girls ; now for the outside effect.

The fact of our employing female labor in our marketgarden produced a perfect uproar in the place. It set the whole town by the ears; indeed, we did not know before that two such quiet people as we could create such an excitement. A few praised our actions, but the greater number of the people condemned us in unmeasured terms. "The Arenac Plaindealer" approved of our doings, and 
thought we had performed a good work, in showing a new field for the labor of girls and women. "The Arenac Bombarder" lectured us severely, and wrote slashing articles after the manner of those newspapers which are just a little behind the age, and very conservative. Nothing was too bad to be said of our disgraceful proceedings. "The reign of fanaticism had begun. The radicals had invaded the village. Society would soon be subverted, and the government overthrown." As for ourselves, we employed the girls as long as we wished, and discharged them when it was convenient, sublimely indifferent to the clamor around us.

Want of time compels me to skip a portion of my story It is impossible to give all the details of our doings. You have seen how we started, and after we were fairly under way the work became in a measure uninteresting. Not that it lost interest to us, but that our days were passed very much as I have described, and, therefore, an account of them would be mere uninteresting repetition.

Three times a week our ancient horse, "Bonaparte." as we called him, carried our crops to market. Sometimes he had a large load, and at other times a lighter one, as our crops varied greatly in their time of ripening. The largest money return we received for a load was forty dollars, and the smallest six dollars. As one crop ceased to produce 
anything it was pulled up, the ground again prepared, and some other crop put in. In this way nearly all our land bore two heavy crops during the season. If we had not followed some such course we could not have obtained the result we did.

One cool October afternoon, while the leaves were falling from the trees, and a purple mist lay on the far-away hills, I went out about sundown to see the flame and gold spread over Mount Arenac, and to take a short walk over our now nearly empty farm. All our crops have matured save the fall cabbages and the cucumbers. All traces of the others have disappeared, and the greater part of the field presents about the same appearance that it did when we came here six months ago. As I walked along I could not fail to contrast the present time with those first days when we came here, tired and half-sick, and started with doubtful steps in an untried field. Now we were both well, strong, and contented; happy in each other's company, and in a position of comparative independence. We have settled the question, - Farming can be made to pay. Robert's health is now so well established that $I$ suppose we shall soon return to the city; yet I shall be sorry to go. Life is quiet, but very pleasant here. We have made many new acquaintances. Comfort, our friend and neighbor, is a treasure in her way; the two Stamford girls 
are companions no one would despise, sensible, well educated, and altogether charming.

And now we must leave them all, and many others equally pleasant. How I wish we need not! I wonder if it is not possible to spend the winter here? 'If it were only summer always we could support ourselves with ease, and could stay as long as we desired. I wonder if Robert could not find employment of some kind in the village for a few months, and so bridge over the winter. There he is, standing by the gate, talking with Mr. Kempenfielder. I'll go and ask him. As I came up I found they were comparing notes on our crops.

"So your sass farm paid its way, did it?"

"Yes, it did more than that. It paid for the care of the place, our support, and a little more."

"Well, well, it's mor'n I'd thought. Did you sell all your stuff? You had a mighty pile of it any way. I never seen such crops raked off any land before. Specks it was the manure that did it. Did you sell everything you growed?"

"Everything."

"What! them cabbages standing there? Are they sold?"

"Yes, I sold them to the Railroad this morning. I suppose they use them among their laborers on the new branch. 
They effered five cents a head for the lot, and I took it at once."

"Only five cents? That aint much."

"Not much for a single head; but when it comes to over six thousand heads it is quite a sum of money."

"Six thousand heads! Why, that's three hundred dollars for the lot."

"Exactly."

"Well, well, it do beat all I ever heard tell. I don't wonder your farm paid its way."

Just then Jack came along and handed my husband two letters. Robert opened one of them and began to read it eagerly. While so occupied the sound of approaching wheels broke on our ears, and a heavy travelling carriage drawn by a pair of black horses trotted gayly past our gate. I tried to discover who was in it, but there was such a cloud of dust that I could see nothing at all. Robert was more fortunate. He evidently saw and recognized the occupants; for, as the carriage swept by, he crushed the letter into his pocket, and to my infinite astonishment started on the full run after it, shouting, "Doctor! Doctor! hold on! hold on!"

After a short run he caught up with the carriage, and it stopped. A brief parley was held, and to my still further surprise the horses were turned round and the equipage came 
slowly back toward our gate. Robert had got in, and was talking excitedly with the people inside, whoever they were. Utterly forgetting Mr. Kempenfielder, I stepped into the street to see who had arrived. As the carriage drew up to the gate, the door was thrown open, and out stepped our friend and physician, - the doctor.

"Why, Mrs. Nelson! This is indeed a surprise and a pleasure. I need not ask how you are. I have prima facie evidence of your health before my eyes. And your husband too. I did not know him; he is altogether a new man."

Before I could answer a word Robert jumped out, and assisting a lady to alight brought her to me.

"Julia," said the doctor, "this is Mrs. Nelson, another of my patients. Mr. and Mrs. Nelson are the two young people I told you about. You remember I sent them into the country last spring when they were both nearly dead."

"Indeed, doctor, I did not know I was your patient before," said I, extending my hand to the pleasant little woman before me. "I am glad to see you, madam. Come in, both of you."

"Here, here, Nelson, what are you doing with those horses?"

"Going to put them in the barn." 
"Oh ! no ; we can stop but a few moments."

"Cannot stop! But you must. Come, let me put them up while you stay to tea, or stay all night, or stay a week,

— which ever you like."

"Really, Nelson, we must not. We have no time."

"Now, doctor, just listen to me. The last time I saw you, you gave me a prescription. I took it. It saved my life, as you see."

"Should say it did."

"Yes; and if you imagine $I$ am going to let you pass my door, and not come in and make us a visit, you are gloriously mistaken."

Thereupon he led the horses away toward the barn, leaving the doctor and his wife to me. I at once took the cue from my husband's actions, and literally dragged them into the yard.

"Wait a bit, Mrs. Nelson. Don't be in such a hurry. We must stop and see your view. Come, Julia, let us sit down on the door-step and admire. Is it not a lovely prospect?"

"Lovely does not express it. It is grand."

Finding they were making themselves quite at home on our door-step, I sat down myself beside them. After gazing about for a few moments, the doctor's wife broke silence : "What river is that we see far down the valley?" 
" The Hoosensacken."

"And the village?"

" Arenac."

"And the flame-and-gold-colored mountain beyond?"

"Mt. Arenac."

"Well, it is lovely, - it is more than lovely, it is grand. How is it you happened to come to such a charming spot?"

"We not only came to the spot, but it came to us."

"How so?" asked the doctor.

Just then my husband came up.

"Here, Nelson, tell us all about this. How did you happen to light on this charming place? When did you find it, and what have you been doing since I saw you last?"

"My uncle left it to us. We came here last spring, and have farmed it ever since."

"You don't say! I congratulate you ; but I hope he left you plenty of money to carry it on. Farming does not pay as an investment."

"So I am told. Uncle Jacob did leave us a little money, but not enough to support us in idleness. We have both of us worked hard, and have earned a fair reward."

"In health."

"Yes; and in money too."

"Really, you surprise me. But then, I knew you would 
succeed in anything if you put your mind to it. Come, tell us more about it. I am vastly interested."

"So I will, after supper."

If there is any one thing I pride myself upon it is my house-keeping. When it comes to getting up a supper, I shine. On this occasion I spread myself, and produced a marvel of art in its way, - simple, as became our rural home, but very, very nice. Our guests were delighted, and did ample justice to my skill. After tea Robert lighted a great, roaring wood fire on the hearth, and we all drew up to the cheerful blaze, for the evening was chilly. The doctor and his wife were all impatience to hear about our doings since our arrival in Arenac, and Robert soon gave them a detailed account of all our adventures, very much as $I$ have told you, since we left the city.

"Now, tell us about the financial part. You say you made money by the operation. Give us the figures. They may aid me if $I$ am ever called upon to give any one the same prescription I gave to you with such success."

"Come, Harriet, get out your ledger. You see, doctor, my wife was the clerk of the establishment, and kept the books."

The doctor's wife looked up surprised.

"Why did you do that? I thought your husband was a famous book-keeper." 
"To save time. I could do it as well as he, and so leave him free to work on the farm."

"A very sensible plan," said the doctor.

Here we were startled by a knock at the door. On opening it, I was surprised to find our neighbor, Comfort Jones, on the step.

Here was a chance for a triumph, and I improved it. Our visitors, no doubt, had the usual city ideas of country people. Here was a pet sample of a country lady, and I paraded her before their astonished eyes with an immense deal of satisfaction. They were captivated at once. They had never met a more charming old lady, they said, after she had gone. Robert offered a seat, and, after being introduced, Mrs. Jones sat down with us before the fire, and our circle was complete.

"We were about giving our city-friends some account of our doings since we turned market-gardeners. I suppose you have no objection to hearing it also."

"Objection! Oh, no! nothing would afford me greater pleasure. It is the very thing of all others I should like to hear about. I should like especially to hear if it is true that you made money by your farm. Some seem to think you did, and others say it is not possible to make anything sut of so small a place."

"The very point I was trying to get at," said the doctor. 
So I got out my ledger, and Robert opened it to read such portions as would interest our company.

"In the first place," said he, "I will give you a list of our crops, and what we received for each, and then I will show you some of the bills. You can then compare the two, and see the result for yourselves. The first thing we tried was early peas. We planted half an acre of the 'Daniel O'Rourke' variety. We sold ten barrels at five dollars, and ten at four dollars each, which produced just ninety dollars for the crop. After they were gone we cleaned up the ground and planted it with fall cabbages; but I will tell you more about them soon."

"Planted two crops on the same land ?" asked the doctor.

"To be sure. That is the only way in which to make money."

"Well, I never heard of that before."

"It is the common practice among our best market-gardeners," said Mrs. Jones.

"But how can they do it? Does it not exhaust the land at a fearful rate?"

"So it would if they did not spend money on it at an equally fearful rate."

"That is just the point. It costs so much to do these things, I don't wonder it does not pay." 
"Wait a moment, doctor. Let me' read a few pages more. Next we planted a half acre of 'Early Flat Dutch Turnips.' We laid out the money on the land in the form of manure ' at a fearful rate,' and the result was, to those who had to pull and tie them for market, simply 'fearful.' I never saw so many turnips in my life. There were upwards of thirty-five thousand roots. They brought us an average price of three quarters of a cent apiece, which amounted in the aggregate to two hundred and seventy dollars." .

"Only three quarters of a cent?" said Mrs. Doctor. "Why, we have to pay a shilling a bunch in town, which would be four cents apiece. Somebody must make a profit out of it, if you don't."

"Yes," said my husband, "the jobbers and retailers do make a large profit out of it ; but then they have all the risk and we have none. We sell at once, and for cash, whereas they have to run all the risk of finding purchasers, or having the goods spoil on their hands. The price paid to the grower seems small, but he is insured, and the insurance is worth something."

"Insurance is worth a great deal," said the doctor.

"Then we attempted to grow an acre of Tennisball and Curled Silesia Lettuce, but could not compass it. We only had thirteen thousand heads in all. We received four cents a head for the first thousand, which amounted to forty dol- 
lars, and two cents for the next two thousand, which gave another forty dollars; lastly, we sold eight thousand at one cent each, which gave us eighty dollars more, making in all one hundred and sixty dollars for our lettuce. The rest we lost through ignorance. We let them stand too long, and they went to seed on our hands. Among other things we forced a lot of potatoes, and when the young plants were well started, we planted them out one rainy day. We had something over seven hundred hills; they came in early, and brought a great price. The gross amount was one hundred and ten dollars. To economize room we sowed seed of the 'New Perpetual Spinage Beets' between the potatoes, and harvested sixteen bushels of nice greens, which brought about fifty cents a bushel, or eight dollars for the lot."

"' That was not a very large crop, Nelson."

" No; but you see we got it from land that otherwise would have been idle; besides it only cost the labor and seed, which I suppose amounted to about one dollar. That reminds me of our radish speculation. At my wife's suggestion we planted radishes between the rows of lettuce."

"It was not my idea," said I; "I got it from the books."

"A very sensible plan, Mrs. Nelson," said the doctor. " A few books well read will put one well along on almost any road." 
"As far as I can discover," remarked Mrs. Jones, " they got all their ideas from books."

"Oh! no, not all. If we had followed the books alone, and not used common sense and some out-door practice, we should have failed miserably."

"And yet," said the doctor, "without book I fancy you would have accomplished but little. It was evidently books, brains, and - "

"Yes ; books, labor, and brains carried you through."

"Their case," said Mrs. Jones, "reminds me of Sir Joshua Reynolds' apt reply when asked what he mixed his colors with: "With brains, sir.'"

"You flatter us, Mistress Comfort."

"Comfort! - What a pretty name!"

"Come, Julia, don't run off on a side-track. Let us stick to the turnips and lettuce. Now Nelson, we are ready to hear more. It is wonderfully interesting, - as good as a novel."

"Better than most novels," remarked Comfort; "for it is all real."

"Yes," said I, coming to the defence of the doctor's wife. "Comfort is a nice name, and becomes the wearer, for she is a dear, comfortable body as ever you met."

"Please, Mr. Nelson, give us more lettuce and some cucumbers. I need something cool after that." 
"You shall have it, Mrs. Jones. We'll take up the cucumbers next. After the turnips were pulled up, the ground was covered with cucumbers. In order to do this we pulled up a turnip or two every six feet, and planted a few cucumber-seeds in the empty space. By the time the turnips were ripe the young vines were a foot long, and ready to spread over the ground. By so doing we lost a few turnips, but gained three weeks in time, and made one crop overlap another. The squash-bugs and other destructive insects troubled us greatly; but we showered the vines every morning with wood-ashes and plaster, and so fought the bugs off."

"Yes," said the doctor's wife; " but where did you find out that plaster would keep off the insects?"

" Harriet read it in one of our agricultural papers, - " The Country Gentleman,' I think. Our cucumbers gave us more trouble than any other one crop. Part of them we sold fresh, but the bulk of them went for pickles. The number of young cucumbers we had was something enormous, - seventy thousand, if I remember rightly. The cash return was one hundred and five dollars."

"But was it not a great job to gather them, Nelson?"

"It was, to be sure ; but we employed girls to help us."

" Employed girls!"

"Certainly. They made the very best of pickers and helped us greatly." 
"And helped themselves too, to money, and health, which is worth more than money."

"They did that, I can assure you. They were perfect little giants when they left us."

"It was a capital idea, Nelson. I have lots of girls among my patients who are always ailing slightly. A few weeks of out-door work on such a place as this would set them up for life. But, bless me, it would never do. It is not genteel to work."

"Just what the people about here said," remarked Mrs. Jones. "The mere fact that our friend employed a few girls in his market-garden created a small tempest among the villagers. They, too, thought it not genteel, etc."

"Great geese, all of them."

"Just my idea."

"Now, Nelson, go on, please. Let us hear more."

"To have a variety, we planted a half acre of the 'Early Yellow Six-Weeks Beans.' They did very well. We had about seventy-five bushels, which brought an average price of one dollar and twenty-five cents a bushel, which netted us just one hundred dollars. Lastly, we planted cabbages where the peas, beans, lettuce, and potatoes had been growing, and, after allowing a liberal margin for those that never came to maturity, we harvested seven thousand heads, and sold them all out in one lot for three hundred 
and fifty dollars. Wait a moment; there is one thing I did not notice, radishes."

"Just what I was going to remind you of," said I. I was proud of our radish speculation, and did not wish it forgotten.

"We planted radishes between our lettuce, and pulled and marketed it before the lettuce was incommoded."

"That is carrying things to a pretty fine point, Nelson. How much space did you have between the rows?"

"Twelve inches."

"Only a foot? I should call that farming by a footrule."

"Yes, ours was literally farming by inches. We had a very fair crop of radishes. We packed up and sold one hundred and five dozen bunches. They brought about seventy five cents a dozen bunches, or, in round numbers, seventy-eight dollars. Here is a list of all our crops, and the total amount received for them. It is from our balance sheet:-

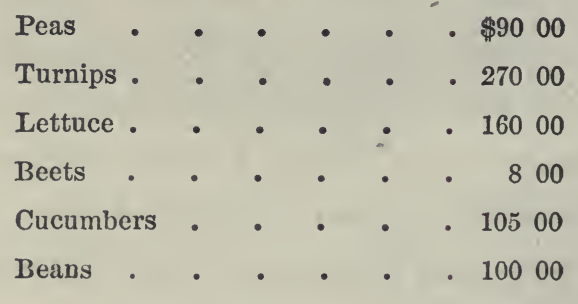




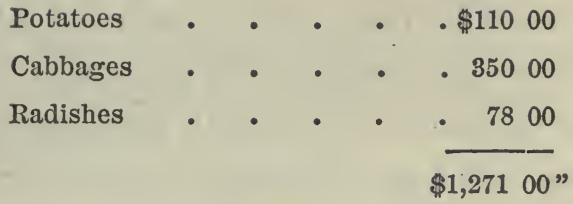

"Now for the cost," said the doctor. "I'll warrant you it nearly came up to that."

$$
\begin{aligned}
& \text { Manure of all kinds . . . } \$ 30000 \\
& \text { Labor of boy, six months . } \quad 15000 \\
& \text { " " } 2 \text { girls, } 30 \text { days . . } 9000 \\
& \text { "6 } 64 \text { " } 4 \text { " } 5 \text { " . . } 3000 \\
& \text { " " men and boys . . } 2400 \\
& \text { Ploughing • • • . } 3200 \\
& \text { Seed . . . . . . } 1000 \\
& \text { Tools . . . . . . } 1500 \\
& \text { Books . . . . . } 300 \\
& \text { Interest on estate, six months . } \quad 3600 \\
& \text { Taxes • • • . . } 800 \\
& \text { Team . . . . . } 5000 \\
& \text { Support of family - • • } 42000 \\
& \$ 1,16800
\end{aligned}
$$

"The grand total of cost is, as you see, one thousand one hundred and sixty-eight dollars."

"Just what I told you. I knew you would make little or nothing by your farm."

"I know it seems a very small profit, only one hundred and three dollars for all our labor; but you must bear in 
mind that our farm supported us both and paid the above profit. Now this is not the whole story ; there are two more items to be entered. You must not think we sold our entire crop, and denied ourselves everything. We were not so foolish as that, I can assure you; we supplied our own table with the best our farm produced, and fairly revelled in fresh vegetables. To the amount of our sales must be added the value of the things used on our table. Then I sold our old horse and wagon for forty dollars, as we have no use for them in the winter. The account then stands somewhat in this wise :-

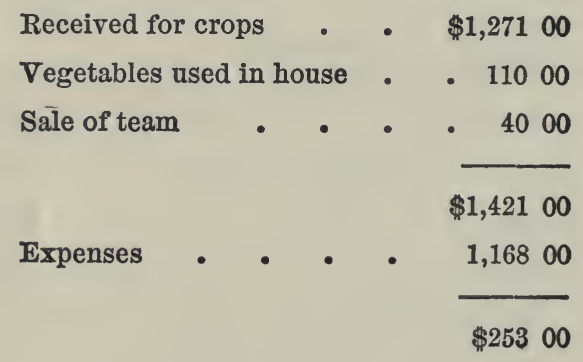

"Our support and two hundred and fifty three dollars, a little more than ten per cent. on the capital used. Our assets are as follows: Real estate, twelve hundred dollars ; furniture and etc., three hundred dollars; tools, ten dollars; cash in Savings Bank, fourteen hundred dollars. Total, two thousand nine hundred and ten dollars. Debts 
none. A very satisfactory statement it seems to me."

"It may seem so to you, but for my part," said the doctor's wife, "I think you two people had to work pretty hard to earn the paltry sum of two hundred and fifty dollars."

"You forget, Julia, that they had their support from it, and made what is considered a fair profit, - ten per cent." .

"Is that not the average return on capital invested in mercantile pursuits?" asked Comfort.

"Yes, most merchants are satisfied with that, and are willing to run every risk to obtain it. As far as I can understand it, Mr. Nelson was almost free from risk. His position was a safe one, as it was independent. No pressure in the money-market could affect him, for as long as people live they must eat. His market was assured to him as long as he chose to supply it. The only risks he does run are those of climate and competition."

"The first, doctor, all trades are. liable to. The storm that throws down my corn may sink another man's ship, or blow over his tall chimney. As for the second, it would be an advantage to have another good gardener next door. We could help each other in various ways, and keep the market more evenly supplied, and, by selling cheap, create 
a market where none existed before. Besides all this, the non-producers, as a class, far outnumber the producers, and are likely to do so for a great many years to come. If our village of Arenac continues to grow as rapidly as it does now, ten years hence it will be a great manufacturing centre, and then a dozen such market-gardens as ours could not furnish the material that would be required to supply its market."

Just here Mrs. Jones rose, and, glancing at the clock, said : -

"Really, I must go. It is nearly ten; quite time I was on my way home. I am sure I am glad I happened in at so fortunate a moment. The account of your doings has greatly pleased me. I can but congratulate you on your success. I always supposed you would manage to get a living from your farm, and am truly glad you have done so much better than that."

Then she shook us each by the hand and bade us goodnight. Robert offered to escort her home, but she declined, as the night was not very dark, and the road short; however, we all thought he had better go, and he went.

"What a pleasant lady your neighbor is! Have you any more like her?"

"Oh, yes! some of our rural friends and neighbors are very sensible, agreeable people." 
"Well, Mrs. Nelson, all I can say is, I think your lines have fallen in pleasant places. I am very glad your husband saw and stopped us as we passed your gate. The story of your experience is one that will aid me, if I ever have a patient in the same position your husband was in last spring. What a change from your city home and life! Viewing your husband's illness from this distance, and in the light of its result, I am very glad he was sick."

"Really, doctor, that is a new view of sickness. I should not have been pleased to hear you give it last winter."

"Very likely. We never know what is best for us. Our blessings are generally disguised in some way."

"For my part," said the doctor's wife, "I fairly envy you, Mrs. Nelson. Such a charming home! You must enjoy life in this little box of a house. It must be a pleasure to take care of such a neat little place. Our great city house and retinue of servants are all very fine at a distance, but, as a home, yours is the best. You have no servants and but little care. We have plenty of both. Henry Ward Beecher once said, that ' $\mathbf{A}$ brown stone front was a means of grace.' He was more than half right."

"Besides," said the doctor, "Mr. and Mrs. Nelson have one other advantage over us city people; for they have 
proved that in their case, the old proverb is true, - ' the happiest people live in the smallest houses." "

Soon after this I lighted a candle and conducted our visitors to their room, as they had travelled a long distance that day and were very tired. At the door I bade them good-night. 


\section{CHAPTER VIII.}

\section{HEALTH, AS A FARM CROP.}

Closing the door behind me, I procured a shawl, wrapped it round me, and sat down by the fire to wait and to think. Then I remembered how I had sat down just in this way once before. There was no need now of gazing at the embers in search of visions of the future. The time for dreaming had passed. A tangible reality was with me now, or would be soon. In a moment or two I heard it enter and with firm steps approach my chair. It sat down by my side, and then there were "four feet on a fender."

"A penny for your thoughts, Hattie."

"I was thinking of my dream."

"What dream?"

"The dream I had one night last winter, when I fell asleep by the fire while watching by your sick room."

"Oh! I remember. What a realization we have had of it!"

"Yes, indeed. It is almost startling so truly has it come to pass. Surely 'God has been a strong castle unto us.' He has saved you from the grave, and restored your health in a way that seems miraculous." 
"It seems so, but is not. He helped us by showing a way in which we could help ourselves. He overstepped no laws to benefit us, but simply aided us, by pointing a road to health through obedience to sanitary laws."

"Well, any way, I am thankful."

"So am I, truly thankful. Thankful also that He has kept us together for another season, and given us a reasonable expectation of many years in each other's company, leaving it a matter for ourselves to decide how long we shall live, within certain limits."

"How can that be?"

"You must admit that we both have good constitutions and are in perfect health at present."

"I do."

"And you see how the carrying out of sanitary measures placed our exhausted and debilitated frames in their present condition. Now, it is but fair to suppose that if we continue to follow the same sanitary rules, we can maintain the high standard of health we now enjoy for an indefinite time. That is, D. V., the Lord willing."

"Yes, but can we? Can we stay here any longer? 'The harvest now is over, the summer days are gone,' and we are not 'saved' - unless we stay here. That we cannot do." .

"Why not?"

"Because you must return to Farwell \& Co. We should 
'quietly starve,' as you say, on the farm during the winter. It is true we have plenty of money in the Savings Bank, but we shall want it all to carry on 'our farming operations next summer."

The only reply I got to this was the unrolling of a crumpled piece of paper, - a letter it seemed :-

"Office of the Arenac Print Works, October 10th.

“Mr. Robert NeLson.

"DeAr Srr: Your application for the vacant clerkship in our office has been considered and accepted by the directors. They have decided to give you a salary of one hundred dollars a month, with the understanding that the engagement shall not continue over six months. At that time it is in contemplation to make some changes in the affairs of the corporation; therefore it is impossible to make any arrangements extending beyond that time. Your desk will be ready for you on and after the 15 th inst.

"Respectfully yours,

"CHARLES JOBSON, Agent."

"Now, isn't that perfectly splendid? Just what we wanted. Why, I almost want to kiss Mr. Dobson or Jobson, whoever be is."

"I would a great deal rather you would kiss somebody else." I did. 
"Now, my dear, come close to me while I whisper a little secret in your ear."

"How can I? There is a limit to proximity."

"Did you know that our little farm produced one crop that, in money value, far exceeds all the rest combined, - in fact, a crop worth the sum of three thousand dollars?"

"Three thousand dollars!"

"Exactly."

"Really, my dear, I do not understand you at all."

"Do you remember how many times I tried when we lived in the city to get an insurance on my life?"

"Yes, I remember it with sorrow. No company was foolish enough to risk its money on such a precarious life as yours."

Just here I felt a curious movement as if something was being drawn forth from somebody's pocket. Looking up, I beheld before my astonished eyes a policy on my husband's life for three thousand dollars.

"There, Hattie, is our latest and best farm crop, - my health. The Arenac Mutual Insurance Company seem to think it so far restored that they value it at the above sum. It is in your favor. Allow me to present the policy to you."

"O Robert, Robert! This is too much happiness." And I kissed him, and kissed him, - but dear me, what am I 
saying? I have quite forgotten myself. This is a story about radishes and lettuce, not sentiment.

On the 15th of October, Robert burst his agricultural shell, mounted his high stool, shook his quill in the ink, and was - a book-keeper. As for me "I minded the house."

About the middle of the following February, it was given out that the Print Works had decided to build a new mill, that would give employment to six hundred hands. On hearing this my husband at once resigned his clerkship, and returned to the farm. If the six hundred new hands and their dependents came into the place, there would be at least one thousand more mouths to be filled. "Sass" would be in demand.

We began our farm work for the second year on the first of March by putting down a number of hot-beds filled with potato, tomato, cabbage, and lettuce-plants. As we had a larger capital to work with, our second year's sales exceeded the first. We spread the manure thicker, ploughed deeper, and cultivated still more carefully. The result was an income of twenty-one hundred dollars, which paid a profit of twelve per cent. on the investment.

The farm after this kept us fully employed all the year round with the exception of a few weeks in the dead of winter.

The third year we started with a cash capital of eighteen 
hundred dollars; fifteen hundred of this was expended for manure. Perhaps you wonder at this. Many people imagine that one dressing is sufficient for several years. This is a great mistake. To compel the land to yield at the rate above mentioned, fertilizers must be ploughed or harrowed in every season, and in the most liberal quantities. The third year, at the suggestion of the market-man, we branched out and tried our hand at strawberries. We planted half an acre, after pulling a crop of early cabbages. It gave us one thousand boxes of berries the next year, which the marketman took at twenty cents a box, and would have taken more if we had only had them. After the berries were gone, the plants were ploughed up in time to plant dandelions for the next spring. You see we made our land give us an income at nearly all seasons of the year. Not an inch of the soil was suffered to remain idle a day, and every inch had to produce all that money, labor, and skill could wring out of it. Our sales the third year almost touched three thousand dollars, and have remained thereabouts ever since.

I wish I could tell you more of our doings. Want of time forbids a further extension of my story. My object in giving you this little sketch of our agricultural experience is to show you, or some one else situated as we were, a safe and profitable field where you can earn both health and bread, if you are so inclined. 
Perhaps you reply, "This is all very fine, but is it true?"

"Yes, in its main features this is a true story of actual experience. The facts and figures $I$ have given you are taken from accounts of bona-fide sales and expenditures of a real market-garden. The originals of most of the characters are still living in New England.

The question is often asked, Does farming pay? This is not a fair question. Does any business pay? Does boatbuilding, or soap-making, or carpentry pay? The question is not, Does farming pay, but, Can you make it pay? This is something I cannot answer, seeing I do not know you personally. I know nothing of your education or capabilities. Some men with the requisite skill and capital would make a fortune out of the manufacture of wooden clothespins. I could not. Whether you could or not is more than I know. If you had a son you designed to put into mercantile life, you would not ask, Does it pay, but, Will my son make a successful merchant?

More and more attention has been turned to farming of late years. Many are thinking of following the example of myself and husband. For them I have but one word: Be sure and farm

"WITH BRAINS, SIR." 



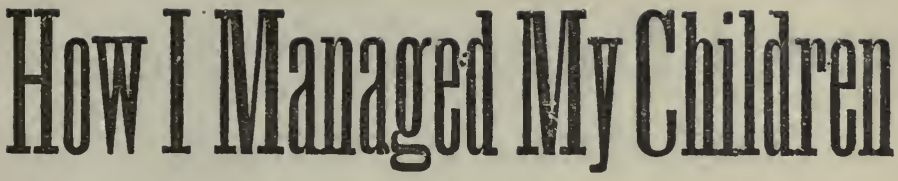

\section{FROM INFANCY TO MARRIAGE.}

\section{BY MRS. WARREN.}

Neat Paper Covers. Price, 50 Cents.

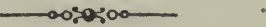

MrS. WARREN, an Finglish lady of sterling sense, large observation and experience, is awakening a deep interest in the now almost "lost art" of managing a house well upon a small income.

Her third book,

\section{"How I Managed My Children from Infancy to Marriage,"}

is a perfect little romance, and has greas popularity in England,

\section{TWENTY THOUSAND COPIES}

having been sold already.

In America this must prove her most successful book, as it is universal in Its application, and the subject is one in which the deepest interest is felt.

A noble Christian mother tells us how she succssfully reared up eight children, carrying them through the perils of infancy, and the impulsiteness of childhood, directing and developing their physical, mental, and religious natures, and pro pared them for useful and creditable positions in life.

The joys, sorrows, and trials, which are the common lot of every loving household, are feelingly told, and the benediction of "Well done, good and faithfus mother," springs up in every reader's heart as the book is closed.

These three volumes form a complete system of Home Economy. 


\title{
How I Managed My House ON $\$ 2 O O$ A YEAR.
}

\author{
BY MRS. WARREN.
}

Neat Paper Covers. - - - Price, 50 Conts. $\longrightarrow \infty 0500$

Ax English kady, of sterling sense, large observation and experience, is the author of three little volumes which must prove a help and comfort to every wearied housewife who encounters them, and afford most useful limits to all whose life-work it is to make a happy home for loved ones.

This fascinating little autobiography of married life has had an unparalleled success in England,

\section{THIRTY-SIX THOUSAND COPIES}

having been sold in the short space of one year. It is as charming a story to read as its companion,

"Our Farm of Four Acres, and the Money we made by it," and, like that, will be equally popular in America, although neither were written expressly for this meridian. $£ 200$, or $\$ 1,000$, represents the income of a very large class in this country.

The earnest wish of every young wife is to nave a house of her own, and - chance to show her husband how well she can keep it. The inability to get, or retain, good "help" often proves a serious drawback in the beginning.

Mrs. Warren's aim in this story is to impart, in a pleasing manner, a practical knowledge of the essential requisites for successful house-keeping with a moderato expenditure of money, and to advise and instruct the inexperienced young wifo, so that she, and not the servant, shall rule the house.

The sririt of the book is universally needed just now. The writer is full of a frank good-humor and practical philosophy. She inspires one with courage, and teaches us to build up a success from fary falure, or, as she facetiously expresses it, "To fall always on our feet.:

If every young house-keeper will read this "Experience" thoughtfully, and embody in her dally life the spirit (not the letter) it teaches, she will find her bunden lightcned, her trials less, and her home mude more joyous and attractive. 





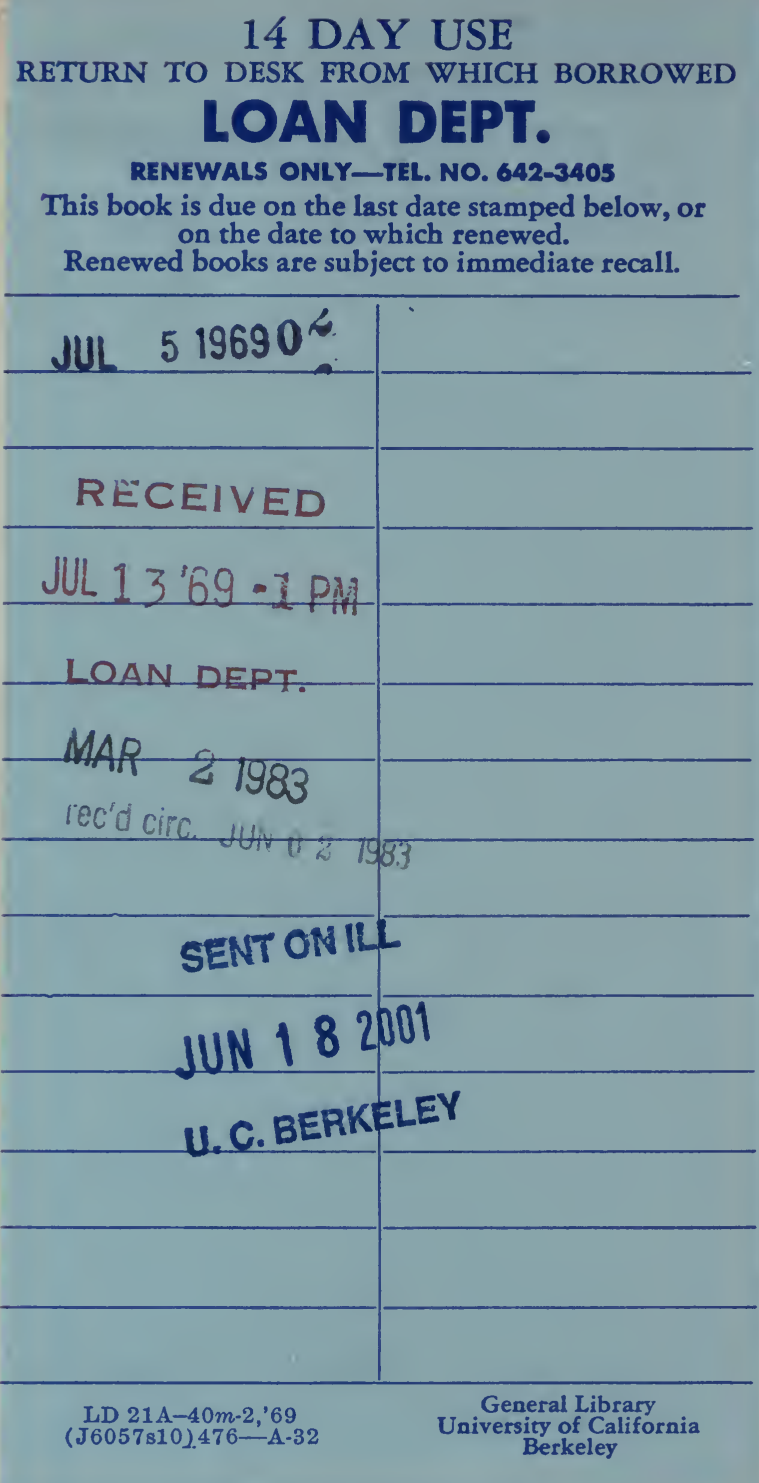


YC 59303 
